University of Windsor

Scholarship at UWindsor

\title{
Comparisons between Tethyan Anorthosite-bearing Ophiolites and Archean Anorthosite-bearing Layered Intrusions: Implications for Archean Geodynamic Processes
}

Ali Polat

Paul Sotiriou

University of Windsor

Follow this and additional works at: https://scholar.uwindsor.ca/environmentalsciencepub

Part of the Geochemistry Commons, Geology Commons, and the Tectonics and Structure Commons

\section{Recommended Citation}

Polat, Ali and Sotiriou, Paul. (2020). Comparisons between Tethyan Anorthosite-bearing Ophiolites and Archean Anorthosite-bearing Layered Intrusions: Implications for Archean Geodynamic Processes. Comparisons between Tethyan Anorthosite-bearing Ophiolites and Archean Anorthosite-bearing Layered Intrusions: Implications for Archean Geodynamic Processes.

https://scholar.uwindsor.ca/environmentalsciencepub/110

This Article is brought to you for free and open access by the Earth \& Environmental Sciences at Scholarship at UWindsor. It has been accepted for inclusion in Earth \& Environmental Sciences Publications by an authorized administrator of Scholarship at UWindsor. For more information, please contact scholarship@uwindsor.ca. 


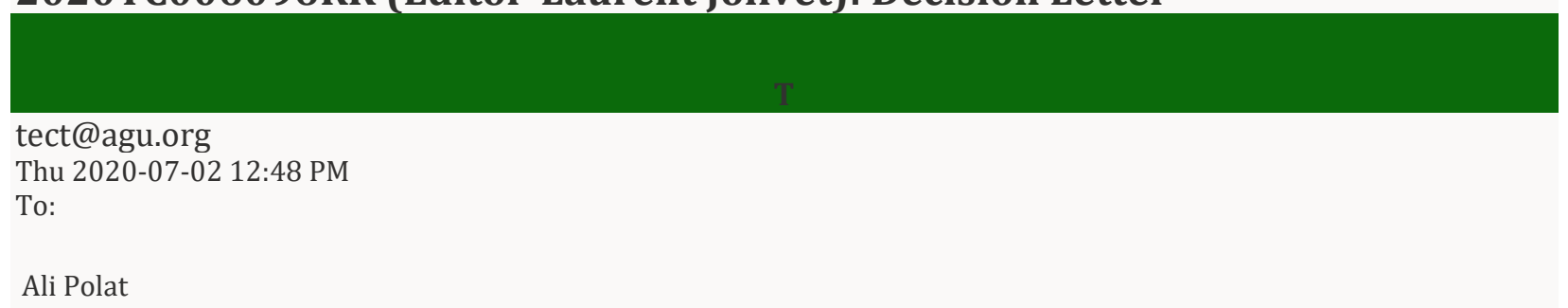

Dear Dr. Polat:

Thank you for submitting your work to Tectonics. I am pleased to accept your manuscript, "Comparisons between Tethyan Anorthosite-bearing Ophiolites and Archean Anorthositebearing Layered Intrusions: Implications for Archean Geodynamic Processes" [Paper \#2020TC006096RR], for publication in the journal.

The publication-ready files you provided will be forwarded to our publishing partner, Wiley, who will manage the production process. Unless you have contacted AGU Publications about a special publication schedule, your article will be published on the journal's website as an Accepted Article within one week of receipt of this letter. It will receive a formal DOI and be considered published.

The posting of your Accepted Article may be slightly delayed from normal operations resulting from an unexpected backlog with our production vendor. If you have questions, please contact TECTprod@wiley.com.

As your paper is accepted, no changes of a technical or substantive nature can be made without obtaining the editor's approval. Authorship is considered to be final, and any changes, if approved, will require a formal correction.

During the next week, you will receive an email from Wiley Author Services with information on completing copyright transfer forms and tracking the progress of your paper through production. Any questions should be directed to the Wiley contact provided in the Author Services email.

Tectonics is now accepting submissions for potential cover images. Cover images can be taken from papers, or they can be images or photographs which relate to a paper but do not appear in the paper. Cover images should be in color and have a resolution of at least $300 \mathrm{dpi}$. If you would like to submit an image for consideration, please send it (along with a short caption) to tect@agu.org.

Sharing your work is an important part of the research process, and AGU leverages and shares published research to promote the broader importance of Earth and space science.

Information on what you can do to share your research and other resources are here.

Thank you again for submitting your work to Tectonics. 
46

47

48

49

50

51

52

53

54

55

56

57

58

59

60

61

62

63

64

65

66

67

68

69

70

71

72

73

74

75

76

77

78

79

80

81

82

83

84

85

86

87

Sincerely,

Laurent Jolivet

Editor

Tectonics

If any reviewers made annotations to the pdf, there will be a link to the pdf.

(2)

1

63

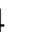

6

8

0

2

3

4

6

7

9

1

82

83

85

87


88 Comparisons between Tethyan Anorthosite-bearing Ophiolites and Archean Anorthosite-bearing Layered Intrusions: Implications for Archean Geodynamic Processes

94 Key Points:

- Tethyan ophiolite-hosted anorthosites are analogous to Archean anorthosites and both largely formed at oceanic convergent plate margins.

97

- Archean anorthosite-bearing layered intrusions and associated greenstone belts are dismembered subduction-related ophiolites.

- Geological characteristics of Archean terrains are consistent with the operation of plate tectonics since the Eoarchean. 


\section{Abstract}

Elucidating the petrogenesis and geodynamic setting(s) of anorthosites in Archean layered intrusions and Tethyan ophiolites has significant implications for crustal evolution and growth throughout Earth history. Archean anorthosite-bearing layered intrusions occur on every continent. Tethyan ophiolites occur in Europe, Africa, and Asia. In this contribution, the field, petrographic, petrological, and geochemical characteristics of 100 Tethyan anorthosite-bearing ophiolites and 155 Archean anorthosite-bearing layered intrusions are compared. Tethyan anorthosite-bearing ophiolites range from Devonian to Paleocene in age, are variably composite, contain anorthosites with highly calcic $\left(\mathrm{An}_{44-100)}\right.$ plagioclase and magmatic amphibole. These ophiolites formed predominantly at convergent plate margins, with some forming in mid-ocean ridge, continental rift, and mantle plume settings. The predominantly convergent plate margin tectonic setting of Tethyan anorthosite-bearing ophiolites is indicated by negative $\mathrm{Nb}$ and $\mathrm{Ti}$ anomalies and magmatic amphibole. Archean anorthosite-bearing layered intrusions are Eoarchean to Neoarchean in age, have megacrystic anorthosites with highly calcic $\left(\mathrm{An}_{20-100}\right)$ plagioclase and magmatic amphibole and are interlayered with gabbros and leucogabbros and intrude pillow basalts. These Archean layered intrusions are interpreted to have predominantly formed at convergent plate margins, with the remainder forming in mantle plume, continental rift, oceanic plateau, post-orogenic, anorogenic, mid-ocean ridge, and passive continental margin settings. These layered intrusions predominantly crystallized from hydrous $\mathrm{Ca}$ - and Al-rich tholeiitic magmas. The field, petrographic and geochemical similarities between Archean and Tethyan anorthosites indicate that they were produced by similar geodynamic processes mainly in suprasubduction zone settings. We suggest that Archean anorthosite-bearing layered intrusions and spatially associated greenstone belts represent dismembered subduction-related Archean ophiolites.

\section{Introduction}

An anorthosite is a leucocratic medium-grained to megacrystic intrusive igneous rock consisting of $>90 \%$ plagioclase (An0-100) (Ashwal, 1993, 2010; Ashwal and Bybee, 2017). Anorthosites occur as Archean megacrystic anorthosites, Proterozoic massif-type anorthosites, Lunar anorthosites and inclusions or xenoliths within felsic to ultramafic rocks, and occur in layered mafic intrusions, oceanic settings and ophiolites (Wiebe, 1992; Ashwal, 1993, 2010; Ashwal and Myers, 1994; Ashwal and Bybee, 2017). Anorthosites have formed throughout Earth history, occur on every continent and are associated with volcanic and plutonic felsic to ultramafic rocks, with Proterozoic massif-type anorthosites forming the most volumetrically significant examples that can attain batholithic proportions (Wiebe, 1992; Ashwal, 1993, 2010; Ashwal and Myers, 1994; Ashwal and Bybee, 2017). Despite this, the petrogenesis of anorthosites remains enigmatic as indicated by the persistence of the longstanding 'anorthosite problem' (Bowen, 1917; Ashwal, 1993; Latypov et al., 2020). The 'anorthosite problem' centres on the petrogenesis of anorthosites, the composition of the parental magmas to anorthosites, the concentration of plagioclase required to form anorthosites, the tectonic settings in which anorthosites form, and the mechanism(s) of anorthosite emplacement. Despite anorthosites being globally volumetrically 
minor, the resolution of the 'anorthosite problem' has major implications for the crystallization of cumulate igneous rocks, the tectonic settings in which mantle-derived magmas form, whether plate tectonics has operated throughout Earth history and Archean to Phanerozoic crustal evolution and growth. Anorthosites and closely associated leucogabbros are commonly included under the umbrella terms 'gabbros' or 'gabbroic cumulates', indicating that they may be more common than previously thought. Given this and the strong petrogenetic link between anorthosites and volumetrically more important gabbros, understanding the petrogenesis of anorthosites has even more important implications for the petrogenesis of gabbroic cumulate rocks, crustal evolution and growth throughout Earth history and the longevity of the operation of plate tectonics on Earth (Burke, 2011; Furnes et al., 2014; Kusky et al., 2018; Hastie and Fitton, 2019; Bauer et al., 2020; Turner et al., 2020; Guo and Korenaga, 2020; El Dien et al., 2020). Archean megacrystic anorthosite-bearing layered intrusions contain distinctive spherical calcic plagioclase megacrysts up to 45 centimetres in diameter and are thought to be restricted to the Archean (Ashwal, 1993, 2010; Ashwal and Myers, 1994; Ashwal and Bybee, 2017). Given their perceived temporal restriction to the Archean, the petrogenesis and geodynamic settings of Archean anorthosites have important implications for Archean magmatic and geodynamic processes (Ashwal and Bybee, 2017).

Anorthosites occur in numerous Phanerozoic ophiolites that mostly formed in various suprasubduction zone geodynamic settings, namely volcanic arcs, forearcs and back-arcs (Ashwal, 1993, 2010; Polat et al., 2018a). Polat et al. (2018a) highlighted the similarity between Phanerozoic anorthosite-bearing ophiolites and Archean anorthosite-bearing layered intrusions and concluded that the latter formed in arc-rift or back-arc geodynamic settings. Some of the Phanerozoic ophiolites that formed during the opening and closure of the Tethys oceans (Paleo- and NeoTethys) and, therefore, the creation of the Alpine, Dinaride, Balkan, Taurus, Pontide, Caucasus, Zagros and Himalayan mountain ranges (Şengör, 1979, 1990; Dilek and Furnes, 2009; Şengör et al., 2019; Y1lmaz, 2019) contain anorthosites and share petrological and geochemical similarities with Archean anorthosite-bearing layered intrusions (see Polat et al., 2018a). The petrological and geochemical similarities between these Tethyan ophiolites and Archean anorthosite-bearing layered intrusions include the fact that they both contain anorthosite-bearing mafic to ultramafic cumulate sequences that are spatially associated with pillow basalts, and both have depleted, subduction-derived N-MORB-normalized trace element patterns exhibiting variably negative $\mathrm{Nb}$ Ta-Ti anomalies and high large-ion-lithophile abundances (Dilek and Thy, 2009; Dilek and Furnes, 2009, 2011, 2014; Pearce, 2014; Ashwal and Bybee, 2017; Polat et al., 2018a). Given these similarities and considering the fact that they formed in the Phanerozoic and Archean, respectively, a comparison of the field, petrographic and geochemical characteristics and petrogenetic and geodynamic interpretations of Tethyan and Archean anorthosites will offer important insights into Archean magmatic and geodynamic processes. Furthermore, Tethyan anorthosite-bearing ophiolites offer an opportunity to better understand the petrogenesis and geodynamic settings of relatively modern anorthosites in the context of the well-studied Tethyan realm (Dilek and Furnes, 2009). Moreover, a comparison between Tethyan and Archean anorthosites may offer insights into 
why calcic megacrystic anorthosites are mainly restricted to the Archean. The characteristics of Tethyan anorthosite-bearing ophiolites and, therefore, their implications for anorthosite petrogenesis and mechanisms of crustal evolution and growth throughout Earth history have not been reviewed in the literature (see Dilek and Furnes, 2009).

In this contribution, the geological and geochemical characteristics of 100 Tethyan anorthositebearing ophiolites and 155 (211 occurrences) Archean anorthosite-bearing layered intrusions are reviewed. The evidence presented in the literature for the parental magmas and geodynamic settings proposed for the reviewed Tethyan and Archean anorthosite occurrences are evaluated to constrain the validity of these interpretations. The characteristics and nature of these Tethyan ophiolites and Archean anorthosites are compared to elucidate how anorthosites formed in the Archean, the tectonic settings in which these anorthosites formed and their parental magma compositions. These findings will have major implications for anorthosite petrogenesis, Archean and Phanerozoic crustal evolution and growth, and the geodynamic settings of Archean and Phanerozoic anorthosites.

\section{Geological Background and Data Presentation} 2.1 Tethyan anorthosite-bearing ophiolites

Tethyan anorthosite-bearing ophiolites occur in a belt that stretches from northwestern Africa to China and are scattered across the Alpine-Himalayan mountain belts, such as the Alps, Dinarides, Balkans, Taurides, Pontides, Caucasus, Zagros, Himalayas and Maghrebides (see Figures 1-2; Figures S1-S4; Table S1; Şengör, 1990; Dilek and Furnes, 2009). The most wellstudied major Tethyan anorthosite-bearing ophiolites are shown in Figures 1-2, Table 1, Figures S1-S4 and Table S1. The major field and petrological characteristics and anorthite contents of these ophiolites and their interpreted tectonic settings are listed in Table S1. These ophiolites underwent greenschist- to granulite-facies metamorphism and variable deformation (Table S1).

The Tethyan ophiolites listed in Table S1 are the products of the closure of the Paleo- and NeoTethys, vary in age from Devonian to Paleocene and range in size from $7 \mathrm{~km}^{2}$ to up to $12,000 \mathrm{~km}^{2}$ (Şengör, 1990). These anorthosite-bearing ophiolites originated from the opening and closure of the Tethys oceans, range from being highly fragmented (ophirags) and displaying an incomplete idealized ophiolite sequence (e.g. Koziakas, Greece) to preserving a near-complete, Penrose-type idealized ophiolite sequence (e.g. Troodos, Cyprus; Pindos, Greece; Mirdita, Albania; Kızıldağ, Turkey; Semail (Oman), Oman; Neyriz, Iran; Chilas Complex, Pakistan; Figure 2; Table S1; Anonymous, 1972, Dilek and Furnes, 2009, 2011). The majority of Tethyan and non-Tethyan anorthosite-bearing ophiolites and ophiolites in general do not preserve complete idealized ophiolite sequences and are variably composite (Şengör and Y1lmaz, 1981; Okay and Tüysüz, 1999; Şengör and Natal'in, 2004; Dilek and Furnes, 2009, 2011; Furnes and Safanova, 2019; Şengör et al., 2019; Y1lmaz, 2019).

An idealized anorthosite-bearing ophiolite section comprises, from top to bottom, marine sedimentary rocks, massive to pillowed ultramafic to felsic lavas and a sheeted dyke complex, an anorthosite-bearing mafic to ultramafic cumulate sequence, and a mantle section of harzburgites, 
dunites, and chromitites (see Figure 2; Table S1). Plagiogranites intrude the lava, sheeted dyke complex and cumulate sequences (see Figure 2; Table S1; Dilek and Furnes, 2011, 2014). Anorthosites usually occur as centimetre- to decimetre-thick layers in Tethyan and non-Tethyan anorthosite-bearing ophiolites; however, the Cretaceous Neyriz Ophiolite (Iran) has an anorthosite sequence up to hundreds of metres thick (see Figure 2; Table S1; Sakkarinejad, 2003). The Cretaceous Chilas Complex Ophiolite (Pakistan) has numerous anorthosite layers up to 1 metre thick (Takahashi et al. 2007). The anorthosites in Tethyan anorthosite-bearing ophiolites contain fine-grained to megacrystic calcic $\left(\mathrm{An}_{44-100}\right)$ plagioclase.

\subsection{Archean anorthosite-bearing layered intrusions}

Archean anorthosite-bearing layered intrusions occur on every continent and form a volumetrically minor part of many of the Earth's main cratons (see Figure 3). The most wellstudied Archean anorthosite-bearing layered intrusions are shown in Figures 3-4, Table 2, and Table S2. A summary of the geological features of selected Archean anorthosite-bearing layered intrusions is presented in Table $\mathrm{S} 2$.

Archean anorthosite-bearing layered intrusions range in age from Eoarchean to Neoarchean ( $\geq 3950 \mathrm{Ma}$ to $\geq 2500 \mathrm{Ma}$ ) and vary in size from $<1 \mathrm{~km}^{2}$ to $>6,000 \mathrm{~km}^{2}$ (see Figure 3 ; Table S2). These intrusions occur as separate bodies, within greenstone belts or as enclaves within tonalitetrondhjemite-granodiorite (TTG) batholiths (Table S2). Archean megacrystic anorthosite- and leucogabbro-bearing layered intrusions form $\sim 60 \%$ of the Archean anorthosite-bearing layered intrusions occurrences listed in Table S2. These intrusions form an integral, yet volumetrically minor part of Archean cratons worldwide and usually form part of and intrude into greenstone belts (Ashwal, 1993, 2010; Ashwal and Myers, 1994; Ashwal and Bybee, 2017; Polat et al., 2018a). Such megacrystic anorthosite- and leucogabbro-bearing layered intrusions intrude spatially and temporally associated pillow basalts and are intruded by TTG batholiths (Windley and Garde, 2009; Polat et al., 2018a). Anorthosites in Archean anorthosite-bearing layered intrusions can attain thicknesses of up to hundreds of metres and contain medium-grained to megacrystic (up to 45 centimetres in diameter) calcic (up to $\mathrm{An}_{100}$ ) plagioclase (Figures 4-5; Table $\mathrm{S} 2)$.

Based on textural and chemical evidence, amphibole in some Archean anorthosite-bearing layered intrusions has been interpreted to be of magmatic origin and be indicative of hydrous magmatism (Rollinson et al., 2010; Polat et al., 2011; Hoffmann et al., 2012; Mohan et al., 2013; Piaia et al., 2017; Santosh and Li, 2018; Sotiriou et al., 2019a, 2020). The textural evidence for magmatic amphibole includes serrated igneous boundaries with calcic plagioclase, whole-grain optical continuity and extinction, its occurrence as interstitial oikocrysts and its anhedral form (Rollinson et al., 2010; Polat et al., 2011; Hoffmann et al., 2012; Mohan et al., 2013; Piaia et al., 2017; Santosh and Li, 2018; Sotiriou et al., 2019a, 2020). This textural evidence distinguishes magmatic amphibole from metamorphic amphibole, which does not have serrated grain boundaries, does not occur as interstitial oikocrysts and is euhedral (Sotiriou et al., 2020). Primary magnesiohornblende can also be distinguished from metamorphic actinolite in these layered 
intrusions based on its higher Si apfu values (Leake et al., 1997; Sotiriou et al., 2020). The 2743 Ma Mayville Intrusion in the Superior Province of Canada has well-preserved magmatic amphibole; however, some recrystallization to secondary actinolite has occurred (Sotiriou et al., 2020).

The ca. 2973 Ma Fiskenæsset Complex of western Greenland is one of the largest and the most studied Archean anorthosite-bearing layered intrusions in the world (Myers, 1985; Windley and Garde, 2009; Polat et al., 2009, 2010, 2011). Despite multiple phases of ductile deformation and up to lower granulite-facies metamorphism, the primary field relationships, and magmatic structures and textures are well preserved throughout the intrusion (Windley and Smith, 1974; Myers, 1985; Polat et al., 2009, 2010, 2011). The intrusion contains well-preserved dunite, hornblende peridotite, hornblende pyroxenite, hornblendite, gabbro, leucogabbro and anorthosite layers (Myers, 1985; Polat et al., 2009, 2011).

Syn-tectonic TTG magmas intruded the Fiskenæsset Complex along numerous shear zones and dispersed its lithological units as trains of inclusions (Figures 6 and 7) (Myers, 1976; 1985; Windley and Garde, 2009; Polat et al., 2011, 2015). The presence of thrust fault imbrications and regional-scale overturned fold structures (Figure 7) in the Fiskenæsset region, and subduction zone trace element patterns in all units of the Fiskenæsset Complex and in the spatially and temporally associated basalts and TTGs are collectively consistent with convergent margin geodynamic processes in Mesoarchean.

\section{Characteristics of Tethyan and Archean anorthosites}

\subsection{Temporal distribution}

\subsubsection{Temporal distribution of Tethyan anorthosite-bearing ophiolites}

Figure 8 shows that Tethyan anorthosite-bearing ophiolites range in age from Devonian to Paleocene. Tethyan anorthosite-bearing ophiolites formed in each of the periods between the Devonian and Paleocene but predominantly formed in the Jurassic and Cretaceous (see Figures 8$13)$.

\subsubsection{Temporal distribution of Archean anorthosite-bearing layered intrusions}

Figures 8-13 show that Archean anorthosites range from Eoarchean to Neoarchean in age ( $\geq 3950$ to $2500 \mathrm{Ma}$ ). Neoarchean anorthosite-bearing layered intrusions predominate, followed by those of Mesoarchean, Paleoarchean and Eoarchean age (see Figures 8-13).

\subsection{Plagioclase anorthite content variations}

\subsubsection{Tethyan anorthosite-bearing ophiolites}

Anorthosites in Tethyan anorthosite-bearing ophiolites are mainly characterized by highly calcic plagioclase (Figure 13; Table S1). The anorthite content ranges from An 44 to $\mathrm{An}_{100}$, with the 
more calcic compositions $\left(\mathrm{An}_{70-100}\right)$ representing the crystallization of magmatic plagioclase and the more sodic compositions $\left(\mathrm{An}_{44-60}\right)$ indicating the formation of metamorphic plagioclase (see Ashwal, 1993, 2010; Ashwal and Bybee, 2017; Table S1). The most frequent anorthite content of plagioclase from these ophiolites is An90, closely followed by An85-86 and An88 (Figure 11). The majority ( $88 \%$ ) of these highly calcic anorthosite-bearing ophiolites have been interpreted to have formed in a subduction-related geodynamic setting, with the remainder forming in mid-ocean ridge or nascent ocean basin settings (Figure 11; Table S1). These findings highlight the strong link between subduction zone processes and highly calcic anorthosites (see Polat et al., 2018a).

\subsubsection{Archean anorthosite-bearing layered intrusions}

Like Tethyan ophiolites, Archean anorthosite-bearing layered intrusions also have predominantly very calcic plagioclase (Figures 13-14; Tables S1 and S2). The anorthite content varies from $\mathrm{An}_{20}$ to $\mathrm{An}_{100}$; however, most have plagioclase that is quite calcic, and a substantial proportion have narrow-ranging, high anorthite contents (see Figure 14; Table S2). The most frequent anorthite content of plagioclase from these layered intrusions is $\mathrm{An}_{70}$ followed by $\mathrm{An}_{76}$ and $\mathrm{An}_{80}$ (Figure 14). There is more variability in the anorthite content of plagioclase from Archean anorthosites compared to Tethyan anorthosites, an observation that most likely reflects the fact that the former have been subjected to more metamorphic events and associated deformation and alteration than the latter (Ashwal, 1993, 2010; Ashwal and Bybee, 2017). The greater variation in the anorthite content of plagioclase from Archean anorthosites compared to Tethyan anorthosites may also reflect different petrogenetic processes, and the wider range of geodynamic settings in which the former were emplaced (Ashwal, 1993, 2010; Ashwal and Bybee, 2017).

The maximum anorthite content of plagioclase from Archean anorthosites was consistently high from the Eoarchean to Neoarchean (see Figure 14; Table S2). Of the 63 Archean anorthosites that have calcic plagioclase, $46(73 \%)$ were interpreted to have formed in a subduction zone setting (see Figure 14; Table S2). Most of the subduction zone setting interpretations proposed for Tethyan and Archean anorthosites (Table S2) have been based on high-precision incompatible element geochemistry (e.g., negative $\mathrm{Nb}-\mathrm{Ti}$ anomalies; narrow-ranging low $\mathrm{Nb} / \mathrm{Th}$ and $\mathrm{Nb} / \mathrm{La}$ ratios), isotope geochemistry and mineral chemistry (e.g., plagioclase, chromite), and detailed field observations (Table 3; Tables S1 and S2). There are some subduction zone setting interpretations in Tables S1 and S2 that may not be based on all these lines of evidence; however, all the subduction zone setting interpretations have been based on incompatible element geochemistry and field observations. This supports the strong link between calcic anorthosites and subduction zone processes.

\section{Discussion}

\subsection{Parental magmas}

\subsubsection{Parental magmas to Tethyan anorthosite-bearing ophiolites}


The composition of the parental magmas to Tethyan anorthosites have largely been proposed based on their major and trace element geochemistry and/or chromite chemistry (Table S1). It has been recognised that it is difficult to accurately constrain the parental magma composition of anorthosites in Phanerozoic ophiolites because of their cumulate origin (Ashwal, 1993); however, it has been shown that the high-precision major and trace element geochemistry of anorthosites is reflective of their parental magmas (Ashwal, 1993; Polat et al., 2011). The majority of the parental magma compositions proposed for Tethyan anorthosites are based on high-precision major and trace element geochemistry and/or chromite chemistry, indicating that the parental magma compositions listed in Table $\mathrm{S} 1$ are most likely reflective of the magmas from which Tethyan anorthosites crystallized.

Although 52\% of the Tethyan anorthosite-bearing ophiolites listed in Table S1 were interpreted to be of boninitic affinity, only $8 \%$ of the anorthosites in these Tethyan ophiolites were interpreted to have actually directly crystallized from a boninitic parental magma (see Figure 12). Over threequarters (75\%) crystallized from tholeiitic basalt magmas, with island arc tholeiitic (14\%), picritic (2\%) and calc-alkaline (1\%) magmas proposed for the remaining anorthosite-bearing ophiolites (Figure 12). The Devonian to Triassic and Paleocene age anorthosite-bearing ophiolites all crystallized from tholeiitic magmas (Figure 12; Table S1). The proportion of Jurassic (81\%) and Cretaceous (66\%) age ophiolites that crystallized from tholeiitic magmas is lower than those of Devonian to Triassic and Paleocene age. Moreover, there is a greater proportion of Tethyan anorthosites of Jurassic (10\% and 7\%) and Cretaceous (20\% and 10\%) age that crystallized from island arc tholeiitic and boninitic magmas, respectively (Figure 12; Table S1). Furthermore, approximately $3 \%$ of Cretaceous and $2 \%$ of Jurassic age Tethyan anorthosite-bearing ophiolites, respectively, crystallized from picritic and calc-alkaline magmas (Figure 12; Table S1). The considerable variation in the parental magmas to Tethyan anorthosite-bearing ophiolites can be accounted for by the fact that many ophiolites are composite and crystallized from more than one magma (Dilek and Furnes, 2009, 2011, 2014; Furnes et al., 2014, 2015).

\subsubsection{Parental magmas to Archean anorthosite-bearing layered intrusions}

The composition of the parental magmas to Archean anorthosites have also largely been proposed based on their major and trace element geochemistry and/or chromite chemistry (Table $\mathrm{S} 2$ ). It is well known that it is difficult to accurately constrain the parental magma composition of Archean anorthosites because of their cumulate origin and age (Ashwal, 1993); however, it has been shown that the high-precision major and trace element geochemistry of Archean anorthosites is reflective of their parental magmas (Ashwal, 1993; Polat et al., 2011). The majority of the parental magma compositions proposed for Archean anorthosites are based on high-precision major and trace element geochemistry and/or chromite chemistry, indicating that the parental magma compositions listed in Table S2 are most likely reflective of the magmas from which Archean anorthosites crystallized.

Archean anorthosite-bearing layered intrusions crystallized from magmas of similar composition to those of the Tethyan anorthosite-bearing ophiolites (Figure 12; Table S2). These 
layered intrusions predominantly crystallized from tholeiitic magmas (59\%), followed by magmas of hydrous Al-rich tholeiitic (20\%), boninitic (12\%), hydrous tholeiitic (4\%), high Al tholeiitic (3\%), komatiitic basaltic (1\%) and island arc tholeiitic (1\%) composition (Figure 12; Table S2). A higher proportion of Archean anorthosite-bearing layered intrusions crystallized from boninitic magmas compared to Tethyan anorthosite-bearing ophiolites, even though a greater proportion of the latter are of boninitic affinity (see Figures 11-12; Tables S1-S2). Approximately $23 \%$ of the Archean anorthosite-bearing layered intrusions in Table S1 crystallized from hydrous and/or Alrich tholeiitic magmas, a characteristic that distinguishes these intrusions from Tethyan anorthosite-bearing ophiolites (Figure 12; Table S2).

\subsection{Geodynamic setting}

\subsubsection{Geodynamic setting of Tethyan anorthosite-bearing ophiolites}

The majority of Tethyan anorthosite-bearing ophiolites have negative $\mathrm{Nb}$ and $\mathrm{Ti}$ anomalies, magmatic amphibole, highly calcic (up to $\mathrm{An}_{100}$ ) plagioclase, pyroclastic andesitic, boninitic and rhyolitic volcanic rocks and arc-derived chromites, characteristics that are indicative of their formation in a subduction zone setting (Table 3; Table S1; Pearce and Peate, 1995; Pearce, 2008; Dilek and Furnes, 2009, 2011, 2014; Furnes et al., 2014). Most of the remaining Tethyan anorthosite-bearing ophiolites formed in a mid-ocean ridge setting, have MORB chromites and low $\mathrm{TiO}_{2} / \mathrm{Yb}$ and $\mathrm{Nb} / \mathrm{Yb}$ ratios, lack negative $\mathrm{Nb}$ and $\mathrm{Ti}$ anomalies and magmatic amphibole, and have variably calcic (An50-90) plagioclase (Table S1; Pearce, 2008, 2014; Dilek and Furnes, 2009, 2011; Furnes et al., 2014). These Tethyan mid-ocean ridge anorthosites are spatially associated with pillow lavas and have plagioclase with anorthite contents that are not as consistently high as those of Tethyan anorthosites that formed in subduction zone settings (Table 3; Table S1; Pearce, 2008, 2014; Dilek and Furnes, 2009, 2011; Furnes et al., 2014).

Tethyan anorthosites have also been interpreted to have formed in rift settings on the basis of their higher $\mathrm{La} / \mathrm{Yb}, \mathrm{Nd} / \mathrm{Sm}$ and $\mathrm{Zr} / \mathrm{Y}$ ratios relative to those that have been interpreted to have formed in subduction zone and mid-ocean ridge settings, negative $\varepsilon_{\mathrm{Nd}}$ values, and were emplaced into older gneisses and are spatially and temporally associated with clastic sedimentary rocks and volcanic rocks (Table 3; Table S1; Pearce, 2008, 2014; Dilek and Furnes, 2009, 2011; Furnes et al., 2014). Mantle plume related Tethyan anorthosites have high $\mathrm{TiO}_{2} / \mathrm{Yb}$ and $\mathrm{Nb} / \mathrm{Yb}$ ratios and are spatially and temporally associated with picrites (Table 3; Table S1; Pearce, 2008, 2014; Dilek and Furnes, 2009, 2011; Furnes et al., 2014). Most of the geodynamic settings proposed for Tethyan anorthosites have been based on a combination of high-precision whole-rock major and trace element geochemistry and field observations. Some of the earlier studies on Tethyan anorthosite-bearing ophiolites listed in Table S1 did not utilize high-precision major and trace element geochemistry; however, their geodynamic interpretations have largely been corroborated by more recent studies.

Tethyan anorthosite-bearing ophiolites have been interpreted to have formed in a variety of geodynamic settings, including arc, forearc, back-arc, mid-ocean ridge, continental rift, and mantle 
plume settings (Figure 9; Table S1). Approximately 77\% of all Tethyan anorthosite-bearing ophiolites formed in subduction-related settings (Figure 10), namely arc, forearc and back-arc. Almost a quarter $(23 \%)$ of the Tethyan anorthosite-bearing ophiolites listed in Table S1 formed in a subduction-unrelated setting (Figure 10). Most of the subduction-unrelated Tethyan anorthositebearing ophiolites formed in a mid-ocean ridge geodynamic setting, with the remainder forming in continental rift and mantle plume settings (Figure 9). In a recent study, Furnes et al. (2020) reached the same conclusions about the tectonic settings of Tethyan ophiolites, indicating that $76 \%$ and $24 \%$ of ophiolites in the Alpine-Himalayan Orogenic Belt have subduction-related and subduction-unrelated origins, respectively.

There is considerable temporal variation in the geodynamic settings of Tethyan anorthositebearing ophiolites (Table S1). This temporal variation in the geodynamic settings of Tethyan anorthosite-bearing ophiolites has implications for the evolution of the Tethys Ocean. The PaleoTethys Ocean most likely underwent contraction because of the subduction of Paleo-Tethyan oceanic crust from the Devonian to Jurassic (Table S1; Şengör and Y1lmaz, 1981; Şengör, 1990; Dilek and Furnes, 2009; Şengör et al., 2019). Opening of the Neo-Tethys Ocean occurred in the Triassic and Jurassic, as indicated by a large proportion of Tethyan anorthosite-bearing ophiolites of these ages having formed in a mid-ocean ridge setting (Dilek and Furnes, 2009, 2011). The contraction and closure of the Neo-Tethys Ocean from the Jurassic to the Eocene is suggested by the increasing proportion of subduction-related Tethyan anorthosite-bearing ophiolites with time (Dilek and Furnes, 2009).

\subsubsection{Geodynamic setting of Archean anorthosite-bearing layered intrusions}

As indicated in Figure 9 and Table S2, most Archean anorthosite-bearing layered intrusions have been interpreted to have formed in an arc or back-arc setting. The subduction zone setting interpretations proposed for these layered intrusions are predominantly based on negative $\mathrm{Nb}$ and $\mathrm{Ti}$ anomalies, narrow-ranging low $\mathrm{Nb} / \mathrm{Th}$ and $\mathrm{La} / \mathrm{Th}$ ratios and close spatial and temporal relationships with volcanic and plutonic rocks that formed in arc settings (Table 3; Table S2). The occurrence of calcic plagioclase megacrysts, magmatic amphibole and arc-derived chromites in these layered intrusions have also been cited as evidence for these subduction zone setting interpretations (Table 3; Table S2). Proponents of vertical tectonics have proposed that negative $\mathrm{Nb}$ and $\mathrm{Ti}$ anomalies reflect element mobility or crustal contamination rather than a subduction zone setting (Bédard, 2006, 2018; Bédard et al., 2013). Crustal contamination and element mobility origins for the negative $\mathrm{Nb}$ and $\mathrm{Ti}$ anomalies exhibited by Archean anorthosite-bearing layered intrusions have been discounted for most of the layered intrusions listed in Table S2 based on their petrography, and trace element and isotope geochemistry. Crustal contamination alone does not rule out the operation of plate tectonics in the Archean, given that this process is common in Phanerozoic Andean-type arcs, continental rifts, and intra-continental hot spots. Subduction zone processes have been shown to be the most efficient and common mechanisms for generating negative $\mathrm{Nb}$ and $\mathrm{Ti}$ anomalies in igneous rocks (Murphy, 2007; Pearce, 2008; Hastie and Fitton, 2019; Roman and Arndt, 2020; van de Löcht et al., 2020). Furthermore, negative Nb anomalies in 
Archean anorthosite-bearing layered intrusions (e.g., Fiskenæsset Complex, Greenland) have been demonstrated to be reflective of their sub-arc mantle wedge sources as opposed to fractional crystallization (Polat et al., 2011).

As is the case with Tethyan anorthosite-bearing ophiolites, most Archean anorthosite-bearing layered intrusions have been interpreted to have formed in a subduction-related geodynamic setting (Figures 9-10; Table S2). A greater proportion (85\%) of Archean anorthosite-bearing layered intrusions formed in a subduction-related setting than Tethyan anorthosite-bearing ophiolites (see Figures 9-10; Tables S1 and S2). Archean anorthosite-bearing layered intrusions are interpreted to have formed in a variety of subduction-related (arc, forearc, back-arc and synorogenic) and subduction-unrelated (mid-ocean ridge, continental rift, mantle plume, oceanic plateau, post-orogenic, anorogenic, passive continental margin and quasi-platform) geodynamic settings (Figure 9; Table S2). The vast majority of subduction-related Archean anorthosite-bearing layered intrusions formed in arc setting, followed by a back-arc setting (Figure 9). Most of the subduction-unrelated Archean anorthosite-bearing layered intrusions are interpreted to have formed in a mantle plume setting (Figure 9; Rowe and Kemp, 2020).

The Archean anorthosite-bearing layered intrusions that have been interpreted to have formed in a mantle plume setting were assigned this tectonic setting based on being spatially and temporally associated with komatiites, komatiitic basalts and picrites, and their high $\mathrm{TiO}_{2} / \mathrm{Yb}$ and $\mathrm{Nb} / \mathrm{Yb}$ ratios (Table 3; Table S2). These layered intrusions have also been interpreted to have formed in an oceanic plateau setting based on the same evidence and having chromites that are suggestive of such a setting (Table 3; Table S2). A mid-ocean ridge setting has been proposed for some Archean anorthosite-bearing layered intrusions having high $\mathrm{TiO}_{2} / \mathrm{Yb}$ and $\mathrm{Nb} / \mathrm{Yb}$ ratios, MORB-derived chromites and low and variably calcic ( $\left.\mathrm{An}_{50-90}\right)$ plagioclase, and lacking negative $\mathrm{Nb}$ and $\mathrm{Ti}$ anomalies and magmatic amphibole (Table 3; Table S2; Furnes et al., 2014). Furthermore, these layered intrusions are spatially associated with MORB pillow lavas (Table 3; Table S2). Archean anorthosite-bearing layered intrusions have also been interpreted to have formed in rift settings based on their higher $\mathrm{La} / \mathrm{Yb}, \mathrm{Nd} / \mathrm{Sm}$ and $\mathrm{Zr} / \mathrm{Y}$ ratios relative to those that have been interpreted to have formed in subduction zone, mid-ocean ridge, and oceanic plateau settings, negative $\varepsilon_{\mathrm{Nd}}$ values, their emplacement into older gneisses and being spatially and temporally associated with clastic sedimentary rocks and volcanic rocks (Table 3; Table S2). The Archean anorthosite-bearing layered intrusions that have been interpreted to have formed in synorogenic, post-orogenic and anorogenic settings were assigned these tectonic settings on the basis of their high $\mathrm{La} / \mathrm{Yb}, \mathrm{Nd} / \mathrm{Sm}$ and $\mathrm{Zr} / \mathrm{Y}$ ratios and their emplacement into Archean gneisses (Table 3; Table S2). As is the case with Tethyan anorthosites, most of the geodynamic settings proposed for Archean anorthosites were based on a combination of high-precision major and trace element geochemistry and field observations. Some of the earlier studies on the Archean anorthosite-bearing layered intrusions listed in Table S2 did not utilize high-precision major and trace element geochemistry; however, their geodynamic interpretations have largely been corroborated by more recent studies that did involve the use of high-precision whole-rock geochemistry. 
Eoarchean anorthosite-bearing layered intrusions formed in arc, forearc, and oceanic plateau geodynamic settings (Table S2). During the Paleoarchean, Archean anorthosite-bearing layered intrusions formed in arc, forearc, and back-arc geodynamic settings (Table S2). By the Mesoarchean, Archean anorthosite-bearing layered intrusions still predominantly formed in subduction-related (arc, back-arc and forearc) geodynamic settings, with $90 \%$ of these forming in such settings (Table S2). The remainder of the Mesoarchean anorthosite-bearing layered intrusions formed in subduction-unrelated (mid-ocean ridge, mantle plume, passive continental margin, and continental rift) geodynamic settings (Table S2). The proportion of subduction-unrelated Archean anorthosite-bearing layered intrusions increased to $17 \%$ in the Neoarchean; however, the vast majority $(83 \%)$ of Neoarchean anorthosite-bearing layered intrusions formed in subduction-related (arc, back-arc, forearc and synorogenic) geodynamic settings (Table S2). The subductionunrelated Neoarchean anorthosite-bearing layered intrusions formed in mantle plume, continental rift, post-orogenic, anorogenic and quasi-platform geodynamic settings (Table S2).

\subsection{Petrogenesis}

\subsubsection{Tethyan anorthosite-bearing ophiolites}

Tethyan anorthosites occur in the layered gabbroic section of ophiolites (Table S1; Furnes et al., 2014). The majority of these formed away from older continental crust, based on their low incompatible trace element abundances, depleted trace element patterns and positive $\varepsilon_{\mathrm{Nd}}$ values (Table S1; Bortolotti et al., 2004; Dilek and Furnes, 2009; Furnes et al., 2014). The vast majority crystallized from tholeiitic or island arc tholeiitic magmas (Figure 12; Table S1; Dilek and Furnes, 2009; Furnes et al., 2014). They have low La/Nb, Th/Nb, Zr/Y, La/Yb and Th/Yb ratios and depleted N-MORB-normalized trace element patterns, corroborating that they are of tholeiitic affinity and were derived by high-degree partial melting of a depleted mantle source (Saunders et al., 1980; Stern et al., 2003; Dilek and Furnes, 2009; Ross and Bédard, 2009; Furnes et al., 2014; Saccani, 2015; Golowin et al., 2017; Table S1). These anorthosites predominantly formed from tholeiitic magmas in mainly subduction zone settings, with some forming in mid-ocean ridge, continental rift, and mantle plume settings. The presence of magmatic amphibole in some of these Tethyan ophiolites indicates that they crystallized from hydrous magmas in an arc setting (Claeson and Meurer, 2004; Jagoutz et al., 2007; Rollinson, 2008; Kakar et al., 2014; Moghadam et al., 2014; Šegvic et al., 2014; Morris et al., 2017). The high anorthite contents (up to $\mathrm{An}_{100}$ ) of plagioclase and the presence of magmatic amphibole in anorthosites from these ophiolites indicate that they crystallized from a hydrous arc tholeiitic magma at shallow depths of 6-9 km (Sisson and Grove, 1993; Takagi et al., 2005). Calcic plagioclase in Tethyan anorthosites has also been shown to have crystallized at shallow depths from anhydrous tholeiitic magmas in a mid-ocean ridge setting, as evidenced by the lack of magmatic amphibole in these anorthosites (e.g., Monte Maggiore, France; Piccardo and Guarnieri, 2011).

Given that $89 \%$ of Tethyan anorthosite-bearing ophiolites have been interpreted to have formed from tholeiitic or island arc tholeiitic magmas and that these ophiolites have calcic (up to $\mathrm{An}_{100}$ ) 
plagioclase, we suggest that most of them crystallized from hydrous Ca- and Al-rich magmas (Takagi et al., 2005). The boninitic affinity Chilas Complex crystallized from an initially hydrous picritic magma (Khan et al., 1989; Jan et al., 1993; Jagoutz et al., 2006, 2007; Hébert et al., 2012; Petterson, 2018). The high $\mathrm{Al}_{2} \mathrm{O}_{3} / \mathrm{TiO}_{2}(>25)$ and $\mathrm{Zr} / \mathrm{Sm}_{\mathrm{N}}(>1)$ ratios and extremely-depleted, Ushaped N-MORB-normalized trace element patterns of a large proportion of well-studied and wellknown Tethyan anorthosite-bearing ophiolites, such as the Troodos, Pindos, Mirdita, Kızıldağ, Semail (Oman) and Neyriz ophiolites, indicate that they had initially boninitic parental magmas (Crawford, 1989; Dilek and Furnes, 2009; Furnes et al., 2014; Table S1). These geochemical characteristics suggest that their initially boninitic parental magmas were derived by large-degree partial melting of an extremely-depleted sub-arc harzburgitic mantle wedge source that was hydrated by slab-derived fluids and metasomatized by slab sediment- or oceanic slab-derived melts (Crawford, 1989; Dilek and Furnes, 2014; Ishizuka et al., 2014; Woelki et al., 2018; Wyman, 2019). Boninites typically lack plagioclase (Crawford, 1989); therefore, the boninitic magmas likely underwent olivine and pyroxene fractionation at depth to form the hydrous Ca- and Al-rich tholeiitic magmas from which Tethyan anorthosites crystallized. Based on this finding, Tethyan anorthosites did not crystallize directly from boninitic parental magmas as proposed by the literature (Table S1), but rather crystallized from hydrous Ca- and Al-rich tholeiitic magmas that fractionated from boninitic parental magmas. Nonetheless, the involvement of boninitic magmas in the petrogenesis of Tethyan anorthosites indicates that they formed at an early stage in the evolution of Tethyan subduction zones in a forearc setting (Crawford, 1989; Stern and Bloomer, 1992; Dilek and Furnes, 2009, 2011; Furnes et al., 2014, 2015).

\subsubsection{Petrogenesis of Archean anorthosite-bearing layered intrusions}

Just as with Tethyan anorthosite-bearing ophiolites, most Archean anorthosite-bearing layered intrusions crystallized mainly from tholeiitic (hydrous Al-rich tholeiitic, hydrous tholeiitic, highAl tholeiitic or island arc tholeiitic) magmas (Figure 12; Table S2). The Neoarchean Black Thor Intrusive Complex in Canada was interpreted to have crystallized from a komatiitic basaltic magma (Figure 12; Table S2; Carson et al., 2015). The low Zr/Y, La/Yb and Th/Yb ratios exhibited by Archean anorthosite-bearing layered intrusions corroborate their interpreted tholeiitic affinity (Table S2; Ross and Bédard, 2009). The high $\mathrm{Ca}$ and Al contents of the anorthosites and leucogabbros from these Archean anorthosite-bearing layered intrusions, combined with their tholeiitic affinity and their having magmatic amphibole, strongly indicate that they crystallized from hydrous Ca- and Al-rich tholeiitic magmas (Table S2; Polat et al., 2018b; Sotiriou et al., $2019 \mathrm{a}, \mathrm{b})$. The positive $\varepsilon_{\mathrm{Nd}}$ values, negative $\mathrm{Nb}$ and Ti anomalies, low incompatible trace element abundances and highly-depleted N-MORB-normalized trace element patterns of Archean anorthosite-bearing layered intrusions indicate that they were generated by high-degree partial melting of very depleted sub-arc harzburgitic mantle wedge sources (Saunders et al., 1980; Pearce and Peate, 1995; Stern et al., 2003; Pearce, 2008; Polat et al., 2011, 2018a; Saccani, 2015; Golowin et al., 2017; Sotiriou et al., 2019a, b, 2020). Archean anorthosites and leucogabbros have high Ca and $\mathrm{Al}$ contents and highly calcic (up to $\mathrm{An}_{100}$ ) plagioclase, indicating that their mantle source may 
have been refertilized by oceanic slab crust-derived $\mathrm{Al}_{2} \mathrm{O}_{3}$ - and $\mathrm{SiO}_{2}$-rich adakitic or TTG melts prior to the generation of their hydrous boninitic and primitve arc tholeiitic parental magmas (Rollinson et al., 2010; Polat et al., 2011; Woelki et al., 2018; Wyman, 2019; Sotiriou et al., 2019a, b). Most Archean anorthosite-bearing layered intrusions crystallized from tholeiitic magmas in a subduction zone setting; however, the remainder crystallized from similar magmas in mantle plume, continental rift, oceanic plateau, post-orogenic, anorogenic, mid-ocean ridge, quasiplatform and passive margin settings (Figures 9 and 12; Table S2).

The boninitic primary magmas likely underwent olivine and pyroxene fractionation at depth to form the hydrous $\mathrm{Ca}$ - and Al-rich tholeiitic magmas from which Archean anorthosites crystallized. In Archean boninitic magmas, fractionation of olivine and pyroxene must have occurred at depth to form the magmas from which anorthosites crystallized. Based on this finding, most Archean anorthosites did not crystallize directly from boninitic parental magmas as proposed by the literature (Table S2), but rather crystallized from hydrous Ca- and Al-rich tholeiitic magmas that fractionated from boninitic primary magmas. Nevertheless, the involvement of boninitic magmas in the formation of Archean anorthosites signifies that they formed early in the evolution of an arc (Crawford, 1989; Stern and Bloomer, 1992; Furnes et al., 2014, 2015).

The identification of magmatic amphibole in gabbroic cumulates has been interpreted to reflect their crystallization from hydrous magmas in a subduction zone geodynamic setting (Claeson and Meurer, 2004). Magmatic amphibole has been identified in anorthosites and leucogabbros in the Archean megacrystic anorthosite-bearing Fiskenæsset, Naajat Kuuat, Bird River, Mayville, Sittampundi, Konkanhundi and São José do Jacuipe layered intrusions, which have all been interpreted to have formed in a subduction zone setting (Rollinson et al., 2010; Polat et al., 2011, 2012; Hoffmann et al., 2012; Mohan et al., 2013; Piaia et al., 2017; Santosh and Li, 2018; Sotiriou et al., 2019a, 2020). The Neoarchean Mayville Intrusion in the western Superior Province of Canada contains abundant well-preserved magmatic amphibole that occurs interstitially to cumulus calcic plagioclase megacrysts (Sotiriou et al., 2020). Magmatic amphibole occurs interstitially to the megacrysts and as oikocrysts that envelop smaller plagioclase crystals in these Archean intrusions (Polat et al., 2011, 2012, 2018a; Hoffmann et al., 2012; Mohan et al., 2013; Sotiriou et al., 2019a, 2020). The magmatic amphibole in these Archean megacrystic anorthositebearing layered intrusions most likely crystallized from an interstitial hydrous melt due to this melt reacting with cumulus plagioclase (Claeson and Meurer, 2004; Sotiriou et al., 2020). These Archean intrusions have been interpreted to have crystallized from hydrous magmas in a suprasubduction zone geodynamic setting (Polat et al., 2011, 2012; Hoffmann et al., 2012; Mohan et al., 2013; Polat et al., 2018a; Sotiriou et al., 2019a, 2020). The oldest magmatic amphibolebearing Archean anorthosites occur in the island arc-related 2985 Ma Naajat Kuuat Complex in western Greenland, suggesting that hydrous arc magmatism has occurred since the Mesoarchean. Archean anorthosite-bearing layered intrusions have anorthosites and leucogabbros that are predominantly comprised of highly calcic (up to $\mathrm{An}_{100}$ ) plagioclase, which indicate that they crystallized from hydrous arc tholeiitic magmas at shallow depths of 6-9 km (Morrison et al., 1985; Phinney et al., 1988; Sisson and Grove, 1993; Takagi et al., 2005). The shallow crystallization 
depths and pressures of Archean anorthosite-bearing layered intrusions is further indicated by the fact that the Mayville Intrusion was found to have crystallized at depths of 6-9 km (average: 7.5 $\mathrm{km}$ ) and pressures of 2-3 kbars (average: $2.5 \mathrm{kbars}$ ). The hydrous $\mathrm{Ca}$ - and Al-rich tholeiitic magmas to Archean megacrystic anorthosites and leucogabbros most likely formed through the fractionation of olivine and pyroxene prior to the accumulation and crystallization of highly calcic plagioclase, amphibole and pyroxene from hydrous tholeiitic magmas at shallow depths (Ashwal, 1993; Hoffmann et al., 2012; Souders et al., 2013; Polat et al., 2018a; Sotiriou et al., 2019a).

\subsection{Are Tethyan calcic anorthosites analogues for Archean calcic anorthosites?}

Calcic anorthosite-bearing layered intrusions were thought to be mostly restricted to the Archean (Ashwal, 1993, 2010; Ashwal and Bybee, 2017; Polat et al., 2018a). The abundance of calcic anorthosites in the Phanerozoic has not been well-documented in the literature. Ashwal (1993) described numerous Phanerozoic calcic anorthosites that form part of ophiolites and layered intrusions and occur as xenoliths and inclusions. Polat et al. (2018a) reported 23 Phanerozoic anorthosite-bearing ophiolites and showed that most of these ophiolites formed in a suprasubduction zone geodynamic setting. Based on the 100 Tethyan anorthosite-bearing ophiolites listed in Table S1, it is proposed here that Phanerozoic anorthosite-bearing ophiolites and calcic anorthosites are far more common than previously thought.

There is still considerable debate regarding the style of tectonics that operated in the Archean, a debate centred around whether uniformitarian (horizontal plate movements) or nonuniformitarian (vertical, sagduction) tectonics was the dominant style (Polat et al., 2012; Foley et al., 2014; Foley, 2018; Kusky et al., 2018; Hastie and Fitton, 2019; Wyman, 2019; Roman and Arndt, 2020; Bauer et al., 2020; Liu et al., 2020; Nutman et al., 2020; van de Löcht et al., 2020). It is well-established that uniformitarian or plate tectonics has been operating throughout the Proterozoic and Phanerozoic right up until the present day (e.g., Furnes et al., 2014, 2015). Indeed, over $82 \%$ of all Phanerozoic anorthosite-bearing ophiolites formed at a mid-ocean ridge or subduction zone, settings that are linked to the operation of plate tectonics with oceanic crust being created at the former and consumed at the latter (Maruyama et al., 2010; Furnes et al., 2014). As such, finding lithologies in the Archean that have petrographical, petrological, mineralogical, and geochemical similarities to equivalents in the Phanerozoic has major implications for whether plate tectonics operated early in the Earth's history.

The anorthosites in Tethyan ophiolites have highly calcic (up to $\mathrm{An}_{100}$ ) plagioclase, contain magmatic amphibole, are often interlayered with leucogabbros and gabbros and are spatially associated with pillow lavas (Table S1). Over three-quarters of Tethyan calcic anorthosite-bearing ophiolites formed in a subduction zone setting and have geochemical (e.g., negative $\mathrm{Nb}$ and $\mathrm{Ti}$ anomalies) characteristics and field (e.g., pyroclastic flows), petrographic (e.g., magmatic amphibole) and mineral chemistry (e.g., chromite) evidence that are strongly indicative of this convergent margin setting (Table S1). Archean anorthosites share many field, petrographical, petrological, mineralogical, and geochemical similarities with Tethyan anorthosites (Tables S1$\mathrm{S} 2$ ). Archean anorthosites are dominated by quite calcic (up to $\mathrm{An}_{100}$ ) plagioclase and contain 
magmatic amphibole (Table S2; Polat et al., 2018a). These anorthosites are often interlayered with leucogabbros and gabbros and often intrude pillow basalts (Polat et al., 2018a). Approximately $85 \%$ of Archean anorthosite-bearing layered intrusions have been interpreted to have formed in a subduction zone geodynamic setting and exhibit geochemical (e.g., negative $\mathrm{Nb}$ and Ti anomalies) characteristics and field, petrographic (e.g., magmatic amphibole) and mineral chemistry (e.g., chromite) evidence that are strongly indicative of this and suggest that they are very similar to Tethyan anorthosites (Tables S1-S2). Tethyan and Archean anorthosites predominantly also have high plagioclase An contents and pyroxene Mg\# that substantially overlap with one another and exhibit positive correlations when plotted (Figure 15), further suggesting that they are analogous and formed from hydrous magmas in a suprasubduction zone setting (e.g., Yamasaki et al., 2006; Goodenough et al., 2014). The high $\mathrm{H}_{2} \mathrm{O}$ contents of these hydrous magmas would have stabilized highly calcic plagioclase and Ca-rich pyroxene (diopside or augite) on the liquidus and facilitated their crystallization (e.g., Takagi et al., 2005). Tethyan and Archean anorthosites predominantly formed in convergent margin settings; however, some formed in subduction-unrelated settings (Figure 16). The involvement of boninitic parental magmas in the petrogenesis of Tethyan and Archean anorthosites suggests that these rocks formed at an early stage in the evolution of Tethyan and Archean arc systems (Crawford, 1989; Stern and Bloomer, 1992; Furnes et al., 2014, 2015).

Evidence for Tethyan calcic anorthosites being analogous to their Archean counterparts is demonstrated by the field, petrological, petrographical, geochemical, petrogenetic and geodynamic similarities between the Mesoarchean Fiskenæsset Complex in Greenland and the Cretaceous Kızıldağ Ophiolite in Turkey, which are prime examples of Archean and Tethyan anorthosite occurrences. The Mesoarchean (ca. $2973 \mathrm{Ma}) 500 \mathrm{~km}^{2}$ Fiskenæsset Complex in the Bjørnesund block of the North Atlantic Craton of Greenland is the most well-studied and wellknown Archean calcic megacrystic anorthosite-bearing layered intrusion in the world (Figures 47; Myers, 1985; Windley and Garde, 2009; Polat et al., 2011, 2018a). This complex intrudes pillow-bearing amphibolites and is intruded by TTG gneisses (Myers, 1976, 1985; Polat et al., 2011). The Fiskenæsset Complex has a total thickness of $\sim 550$ metres and is comprised of anorthosites, leucogabbros, gabbros, pyroxenites, peridotites and chromitites that exhibit wellpreserved igneous layering and minerals and cumulate textures, despite having been subjected to polyphase deformation and amphibolite- to granulite-facies metamorphism (Figure 5; Myers, 1985; Polat et al., 2011). The anorthosites and leucogabbros contain very calcic plagioclase (An 75 98) megacrysts up to 40 centimetres in diameter, alongside magmatic amphibole, clinopyroxene and orthopyroxene (Figure 5; Polat et al., 2011; Huang et al., 2014). These megacrystic anorthosites and the Fiskenæsset Complex as a whole exhibit negative $\mathrm{Nb}$ and $\mathrm{Ti}$ anomalies relative to Th and REE, very low incompatible trace element abundances and positive $\varepsilon_{\mathrm{Nd}}$ values that are not accounted for by or do not indicate alteration-induced element mobility or contamination by pre-existing crust (Polat et al., 2011). Based on these field, petrological, petrographical and geochemical characteristics and mineral chemistry data, the primitive hydrous arc tholeiite parental magma to the Fiskenæsset Complex was interpreted to have formed by highdegree partial melting of a sub-arc hydrous depleted harzburgitic mantle source in a 
suprasubduction zone setting (Polat et al., 2011; Huang et al., 2014). This primary magma underwent olivine and pyroxene fractionation to form the hydrous $\mathrm{Ca}$ - and Al-rich tholeiitic magma from which calcic megacrystic anorthosites and leucogabbros subsequently crystallized at a shallow depth during emplacement into pillow basalt-bearing oceanic crust (Polat et al., 2011, 2018a; Huang et al., 2014). The calcic plagioclase megacrysts in the anorthosites and leucogabbros from this complex formed from this hydrous $\mathrm{Ca}$ - and Al-rich tholeiitic magma due to its remaining at high temperatures $\left(1000-1200^{\circ} \mathrm{C}\right)$ and calcic plagioclase remaining on the liquidus for a protracted period (Polat et al., 2018a). These megacrysts attained their large sizes through a combination of Ostwald ripening and by interaction with new melts or melts expelled from lower down in the magma chamber (Polat et al., 2018a). The diverse trace element patterns exhibited by the Fiskenæsset Complex (Polat et al., 2009, 2011; Huang et al., 2014) likely reflect multiple parental magmas.

The calcic anorthosites in the Cretaceous (92 Ma) Kızıldağ Ophiolite in southeastern Turkey (Bağci et al., 2005; Dilek and Thy, 2009) share close field, petrological, petrographical, geochemical, petrogenetic and geodynamic similarities with the Fiskenæsset Complex. This ophiolite consists of, from bottom to top, tectonized mantle harzburgites, ultramafic to mafic cumulates, plagiogranites, sheeted dykes, basaltic to boninitic (sakalavites) pillow lavas and marine sedimentary rocks (Bağci et al., 2005; Dilek and Furnes, 2009; Dilek and Thy, 2009). The anorthosites alternate with leucogabbros and gabbros and occur in the ultramafic to cumulate section, which is spatially associated with and intrusive into the tholeiitic sheeted dykes that acted as feeders for the basaltic to boninitic pillow lavas above (Bağci et al., 2005; Dilek and Thy, 2009). These field relationships and petrological associations bear close resemblance to the Archean anorthosites in the mafic to ultramafic cumulates of the Fiskenæsset Complex and the amphibolitic rocks derived from pillowed basaltic precursors into which it intrudes (e.g., Polat et al., 2011, 2018a; Huang et al., 2014). The Kızıldağ (An89-94) and Fiskenæsset anorthosites are also petrographically very similar, for they both contain calcic plagioclase and magmatic amphibole, clinopyroxene and orthopyroxene (Bağci et al., 2005; Dilek and Thy, 2009; Polat et al., 2011, 2018a; Huang et al., 2014). Just as with the Fiskenæsset Complex, the Kizıldağ Ophiolite also exhibits the negative $\mathrm{Nb}$ and $\mathrm{Ti}$ anomalies (relative to Th and REE) and very low immobile trace element abundances that are indicative of derivation by high-degree partial melting of a sub-arc hydrous depleted harzburgitic mantle source in a suprasubduction zone setting (Bağci et al., 2005; Dilek and Thy, 2009; Polat et al., 2011, 2018a). The Kızıldağ Ophiolite is of tholeiitic, island arc tholeiitic and boninitic affinity, highlighting the great similarity between the parental magmas to its and the Fiskenæsset Complex's anorthosites (Bağci et al., 2005; Dilek and Thy, 2009; Furnes et al., 2014; Polat et al., 2011, 2018a). Just as with the Fiskenæsset megacrystic anorthosites, the highly calcic plagioclase in the Kızıldağ anorthosites formed from a hydrous tholeiitic magma at a shallow depth under high $\mathrm{P}_{\mathrm{H} 2 \mathrm{O}}$ conditions (Bağci et al., 2005; Dilek and Thy, 2009).

The field, petrological, petrographic, and geochemical similarities between Archean anorthosite-bearing layered intrusions and Tethyan calcic anorthosite-bearing ophiolites strongly indicate that they largely formed by similar processes at convergent plate margins (Figure 16). 
This indicates that Archean anorthosite-bearing layered intrusions and their associated greenstone belts are close analogues of Tethyan and Altaid anorthosite-bearing ophiolites and ophirags (Şengör and Natal'in, 2004). Furnes et al. (2015) and Dilek and Furnes (2011) concluded that Precambrian greenstone belts represent different ophiolite types. Therefore, Archean anorthositebearing layered intrusions and their associated greenstone belts conform to the ophiolite definition proposed by Dilek and Furnes (2011): "suites of temporally and spatially associated ultramafic to felsic rocks related to separate melting episodes and processes of magmatic differentiation in particular tectonic environments." There is a paucity of dome and basin structures, which are thought to be suggestive of vertical tectonics, associated with Archean anorthosite-bearing layered intrusions (Table S2; Bédard, 2006, 2018; Bédard et al., 2013; Polat et al., 2015). This observation, coupled with the occurrence of low-angle thrust faults, indicates that these layered intrusions formed through modern-style plate tectonics rather than vertical, sagduction tectonics (Polat et al., 2015; Sotiriou et al., 2020).

The major differences between Tethyan ophiolites/ophirags and Archean anorthosite-bearing layered intrusions and associated greenstone belts is that the former have a much larger proportion of mantle rocks and thinner anorthosite sequences than the latter. These differences can be attributed to the greater crustal thickness $(20-30 \mathrm{~km})$ of Archean oceanic crust that stemmed from higher degrees of partial melting of the mantle and higher mantle potential temperatures (Sleep and Windley, 1982), resulting predominantly in the accretion of the upper part of the oceanic crust during orogenesis (Kusky et al., 2018). The subduction of 20-30 km thick oceanic crust has been proposed to be unfeasible by advocates of vertical tectonics (Bédard, 2006, 2018; Bédard et al., 2013); however, Hastie and Fitton (2019) demonstrates that subduction of thick oceanic crust did occur and led to the formation of TTGs batholiths. These differences and the more frequent and significant occurrence of slab melting and shallow slab subduction at this time can also account for the greater volume of megacrystic anorthosites and leucogabbros in the Archean (Windley and Garde, 2009; Rollinson et al., 2010; Polat et al., 2011, 2018a). Archean anorthosite-bearing layered intrusions and their host greenstone belts represent dismembered subduction-related Archean anorthosite-bearing ophirags (Şengör and Natal'in, 2004).

\section{Conclusions}

1. Tethyan Devonian to Paleocene anorthosite-bearing ophiolites are more common than previously thought.

2. Tethyan anorthosites have highly calcic (up to $\mathrm{An}_{100}$ ) plagioclase and magmatic amphibole, are interlayered with leucogabbros and gabbros and spatially associated with pillow lavas. Archean anorthosites have calcic (up to $\mathrm{An}_{100}$ ) plagioclase megacrysts and magmatic amphibole, are interlayered with leucogabbros and gabbros and intrude greenstone belts.

3. The majority of Tethyan anorthosite-bearing ophiolites formed in an arc setting, with the remainder forming in mid-ocean ridge, continental rift, and mantle plume settings. Similarly, the majority of Archean anorthosite-bearing layered intrusions formed in an arc setting, with 
the remainder forming in mantle plume, oceanic plateau, continental rift, post-orogenic, anorogenic, mid-ocean ridge, quasi-platform, and passive margin settings.

4. Tethyan ophiolite-hosted anorthosites crystallized from hydrous Al- and Ca-rich tholeiitic magmas that fractionated from more primitive hydrous primary magmas. Archean anorthosites also crystallized from hydrous Al- and Ca-rich tholeiitic magmas.

5. Tethyan ophiolite-hosted anorthosites are analogous to Archean anorthosites and both largely formed at intra-oceanic convergent plate margins.

6. Archean anorthosite-bearing layered intrusions and their host greenstone belts are interpreted to represent dismembered Archean subduction-related ophiolites and ophirags.

7. Lithological characteristics, field relationships, and the geochemistry of Archean anorthositebearing layered intrusions and spatially and temporally associated greenstone belts and granitoids suggest that a form of plate tectonics has been in operation since the Eoarchean.

\section{Acknowledgements}

This research was supported by a NSERC Discovery Grant (RGPIN-2019-04236) awarded to A. Polat. We thank Jean Bédard, Fernando Corfu, Elis Hoffmann, and Tony Kemp for their constructive and helpful comments. There is no conflict of interest for both authors. Upon acceptance, our manuscript and data will be available at Scholarship at UWindsor.

\section{References}

Abbotts, I.L. (1979). Intrusive processes at ocean ridges: evidence from the sheeted dyke complex of Masirah, Oman. Tectonophysics, 60(3-4), 217-233.

Abdulzahra, I.K. (2008). Petrology, Geochemistry and Petrogenesis of gabbroic rocks (Central sector) of Mawat Ophiolite Complex, NE Iraq. University of Baghdad, Doctoral Dissertation, $139 \mathrm{p}$.

Acosta-Gongora, P., Pehrsson, S.J., Sandeman, H., Martel, E., \& Peterson, T. (2018). The Ferguson Lake deposit: an example of Ni-Cu-Co-PGE mineralization emplaced in a back-arc basin setting? Canadian Journal of Earth Sciences, 55(8), 958-979.

Ahmat, A.L., \& Laeter, J.R. (1982). Rb-Sr isotopic evidence for Archaean-Proterozoic crustal evolution of part of the central Yilgarn Block, Western Australia: Constrains on the age and source of the anorthositic Windimurra Gabbroid. Journal of the Geological Society of Australia, 29(1-2), 177-190.

Al Humadi, H., Väisänen, M., Ismail, S.A., Kara, J., O'Brien, H., Lahaye, Y., \& Lehtonen, M. (2019). U-Pb geochronology and Hf isotope data from the Late Cretaceous Mawat ophiolite, NE Iraq. Heliyon, 5(11), e02721. https://doi.org/10.1016/j.heliyon.2019.e02721.

Alparslan, G., \& Dilek, Y. (2018). Seafloor spreading structure, geochronology, and tectonic evolution of the Küre ophiolite, Turkey: A Jurassic continental backarc basin oceanic lithosphere in southern Eurasia. Lithosphere, 10(1), 14-34.

Ames, D.E., \& Houlé, M.G. (2015). A synthesis of the TGI-4 Canadian nickel-copper-platinum group elements-chromium ore systems project - revised and new genetic models and 
exploration tools for Ni-Cu-PGE, Cr-(PGE), Fe-Ti-V-(P), and PGE-Cu deposits. In D.E. Ames, \& M.G. Houlé (Eds.). Targeted Geoscience Initiative 4: Canadian Nickel-Copper-Platinum Group Elements-Chromium Ore Systems - Fertility, Pathfinders, New and Revised Models. Geological Survey of Canada, Open File, 7856, 1-16.

Anhaeusser, C.R. (2019). Palaeo-, Meso- and Neoarchaean granite-greenstone basement geology and related rocks of the central and western Kaapvaal Craton, South Africa. In A. Kröner, \& A. Hofmann (Eds.). The Archaean Geology of the Kaapvaal Craton, Southern Africa. Springer Nature: Switzerland, Regional Geology Reviews, 55-81.

Arif, M., \& Jan, M.Q. (2006). Petrotectonic significance of the chemistry of chromite in the ultramafic-mafic complexes of Pakistan. Journal of Asian Earth Sciences, 27(5), 628-646.

Arvin, M., Babaei, A., Ghadami, G., Dargahi, S., \& Ardekani, A.S. (2005). The origin of the Kahnuj ophiolitic complex, SE of Iran: Constraints from whole rock and mineral chemistry of the Bande-Zeyarat gabbroic complex. Ofioliti, 30(1), 1-14.

Arvin, M., Houseinipour, A., Babaei, A.A., \& Babaie, H.A. (2001). Geochemistry and tectonic significance of basalts in the Dareanar complex: evidence from the Kahnuj ophiolitic complex, southeastern, Iran. Journal of Sciences, 12(2), 157-170.

Ashwal, L.D. (1993). Anorthosites. Springer-Verlag: Berlin, Germany, Minerals and Rocks, 21, 422p.

Ashwal, L.D. (2010). The temporality of anorthosites. The Canadian Mineralogist, 48(4), 711728.

Ashwal, L.D., \& Bybee, G.M. (2017). Crustal evolution and the temporality of anorthosites. EarthScience Reviews, 173, 307-330.

Ashwal, L.D., \& Myers, J.S. (1994). Archean anorthosites. In K.C. Condie (Ed.). Archean Crustal Evolution. Elsevier: Amsterdam, Developments in Precambrian Geology, 11. 315-355.

Attarzadeh, P., Karimi, M., Yazdi, M., \& Khankahdani, K.N. (2017). Geochemistry of Chromitites in Eastern Part of Neyriz Ophiolite Complex (Southern Iran). Open Journal of Geology, 7(03), 213-233.

Awalt, M.B., \& Whitney, D.L., 2018. Petrogenesis of kyanite-and corundum-bearing mafic granulite in a meta-ophiolite, SE Turkey. Journal of Metamorphic Geology, 36(7), 881-904.

Azizi, H., Najari, M., Asahara, Y., Catlos, E.J., Shimizu, M., \& Yamamoto, K. (2015). U-Pb zircon ages and geochemistry of Kangareh and Taghiabad mafic bodies in northern SanandajSirjan Zone, Iran: Evidence for intra-oceanic arc and back-arc tectonic regime in Late Jurassic. Tectonophysics, 660, 47-64.

Bağc1, U. (2013). The geochemistry and petrology of the ophiolitic rocks from the Kahramanmaraş region, southern Turkey. Turkish Journal of Earth Sciences, 22(4), 536-562.

Bağcı, U., Parlak, O., \& Höck, V. (2005). Whole-rock and mineral chemistry of cumulates from the Kızıldağ (Hatay) ophiolite (Turkey): clues for multiple magma generation during crustal accretion in the southern Neotethyan ocean. Mineralogical Magazine, 69(1), 53-76. 
Baker, S.R., \& Boudreau, A.E. (2019). The influence of the thick banded series anorthosites on the crystallization of the surrounding rock of the Stillwater Complex, Montana. Contributions to Mineralogy and Petrology, 174, 99, https://doi.org/10.1007/s00410-019-1635-x.

Barton Jr, J.M. (1996). The Messina layered intrusion, Limpopo belt, South Africa: an example of in-situ contamination of an Archean anorthosite complex by continental crust. Precambrian Research, 78(1-3), 139-150.

Bauer, A.M., Reimink, J.R., Chacko, T., Foley, B.J., Shirey, S.B., \& Pearson, D.G. (2020). Hafnium isotopes in zircons document the gradual onset of mobile-lid tectonics. Geochemical Perspectives Letters, 14, 1-6, doi: 10.7185/geochemlet.2015.

Baumgartner, R.J., Zaccarini, F., Garuti, G., \& Thalhammer, O.A.R. (2013). Mineralogical and geochemical investigation of layered chromitites from the Bracco-Gabbro complex, Ligurian ophiolite, Italy. Contributions to Mineralogy and Petrology, 165(3), 477-493.

Bazylev, B.A., Karamata, S., \& Zakariadze, G.S. (2003). Petrology and evolution of the Brezovica ultramafic massif, Serbia. In Y. Dilek, \&P.T. Robinson (Eds.) Ophiolites in Earth History. Geological Society, London, Special Publications, 218, 91-108.

Beccaluva, L., Coltorti, M., Saccani, E., \& Siena, F. (2005). Magma generation and crustal accretion as evidenced by supra-subduction ophiolites of the Albanide-Hellenide Subpelagonian zone. Island Arc, 14(4), 551-563.

Bécu, V., Houlé, M.G., McNicoll, V.J., Yang, X.M., \& Gilbert, H.P. (2015). Mafic intrusive rocks from the Bird River intrusive suite, Bird River greenstone belt, southeast Manitoba. In D.E. Ames, \&M.G. Houlé (Eds.). Targeted Geoscience Initiative 4: Canadian Nickel-CopperPlatinum Group Elements-Chromium Ore Systems - Fertility, Pathfinders, New and Revised Models. Geological Survey of Canada, Open File, 7856, 49-60.

Bédard, J.H. (2006). A catalytic delamination-driven model for coupled genesis of Archaean crust and sub-continental lithospheric mantle. Geochimica et Cosmochimica Acta, 70, 1188-1214.

Bédard, J.H. (2018). Stagnant lids and mantle overturns: Implications for Archaean tectonics, magmagenesis, crustal growth, mantle evolution, and the start of plate tectonics. Geoscience Frontiers, 9, 19-49.

Bédard, J.H., Harris, L.B., \& Thurston, P.C. (2013). The hunting of the snArc. Precambrian Research, 229, 20-48.

Bédard, J.H., Leclerc, F., Harris, L.B., \& Goulet, N. (2009). Intra-sill magmatic evolution in the Cummings Complex, Abitibi greenstone belt: Tholeiitic to calc-alkaline magmatism recorded in an Archaean subvolcanic conduit system. Lithos, 111, 47-71.

Bell, C.K. (1978). Geology, Wekusko Lake map-area, Manitoba. Geological Survey of Canada, Memoir, 384, 84p.

Berger, J., Diot, H., Lo, K., Ohnenstetter, D., Féménias, O., Pivin, M., Demaiffe, D., Bernard, A., \& Charlier, B. (2013). Petrogenesis of Archean PGM-bearing chromitites and associated ultramafic-mafic-anorthositic rocks from the Guelb el Azib layered complex (West African craton, Mauritania). Precambrian Research, 224, 612-628. 
Bergh, S.G., Corfu, F., Myhre, P.I., Kullerud, K., Armitage, P.E., Zwaan, K.B., Ravna, E.K., Holdsworth, R.E., \& Chattopadhya, A. (2012). Was the Precambrian basement of Western Troms and Lofoten-Vesterålen in northern Norway linked to the Lewisian of Scotland? A comparison of crustal components, tectonic evolution and amalgamation history. In E. Sharkov (Ed.). Tectonics - Recent Advances. Intech, 283-330.

Blichert-Toft, J., Rosing, M.T., Lesher, C.E., \& Chauvel, C. (1995). Geochemical constraints on the origin of the late Archean Skjoldungen alkaline igneous province, SE Greenland. Journal of Petrology, 36(2), 515-561.

Bonev, N., \& Stampfli, G. (2009). Gabbro, plagiogranite and associated dykes in the suprasubduction zone Evros Ophiolites, NE Greece. Geological Magazine, 146(1), 72-91.

Borthwick, A.A., \& Naldrett, A.J. (1986). The geology and geochemistry of the Big Trout Lake layered intrusion, Thunder Bay District. Ontario Geological Survey, Open File Report, 5584, $324 \mathrm{p}$.

Bortolotti, V., Chiari, M., Marcucci, M., Marroni, M., Pandolfi, L., Principi, G., \& Saccani, E. (2004). Comparison among the Albanian and Greek ophiolites: in search of constraints for the evolution of the Mesozoic Tethys Ocean. Ofioliti, 29(1), 19-35.

Boudier, F., \& Nicolas, A. (2011a). Axial melt lenses at oceanic ridges - A case study in the Oman ophiolite. Earth and Planetary Science Letters, 304(3-4), 313-325.

Boudier, F.I., \& Nicolas, A.J. (2011b). Anorthosites in Oman Ophiolite crust, a clue to crust origin at a fast spreading ridge. In $A G U$ Fall Meeting Abstracts.

Boudreau, A.E., Stewart, M.A., \& Spivack, A.J. (1997). Stable Cl isotopes and origin of high-Cl magmas of the Stillwater Complex, Montana. Geology, 25(9), 791-794.

Bowen, N.L. (1917). The problem of the anorthosites. Journal of Geology, 25, 209-243.

Bowes, D.R., Wright, A.E., \& Park, R.G. (1964). Layered intrusive rocks in the Lewisian of the North-West Highlands of Scotland. Quarterly Journal of the Geological Society of London, 120, 153-192.

Bridgwater, D., McGregor, V.R., \& Myers, J.S. (1974). A horizontal tectonic regime in the Archaean of Greenland and its implications for early crustal thickening. Precambrian Research, 1(3), 179-197.

Burke, K. (2011). Plate tectonics, the Wilson cycle, and mantle plumes: geodynamics from the top. Annual Review of Earth and Planetary Sciences, 39, 1-29.

Cabella, R., Garuti, G., Oddone, M., \& Zaccarini, F. (2002). Platinum-Group Element Geochemistry in Chromitite and Related Rocks of the Bracco Gabbro Complex (Ligurian Ophiolites, Italy). In 9th International Platinum Symposium Abstracts: Montana.

Cameron, H.D.M. (1992). Pipestone Lake Anorthosite Complex: geology and studies of titaniumvanadium mineralization. Manitoba Energy and Mines, Geological Services, Open File Report, OF92-1, 141p.

Camuzcuoğlu, M., Bağc1, U., Koepke, J., \& Wolff, P.E. (2017). Tectonic significance of the cumulate gabbros within Kuluncak Ophiolitic suite (Malatya, SE Turkey) inferred from geochemical data. Ofioliti, 42(2), 81-103. 
Carson, H.J.E., Lesher, C.M., \& Houlé, M.G. (2015). Geochemistry and petrogenesis of the Black Thor intrusive complex and associated chromite mineralization, McFaulds Lake greenstone belt, Ontario In D.E. Ames, \& M.G. Houlé (Eds.). Targeted Geoscience Initiative 4: Canadian Nickel-Copper-Platinum Group Elements-Chromium Ore Systems - Fertility, Pathfinders, New and Revised Models. Geological Survey of Canada, Open File, 7856, 87-102.

Çelik, Ö.F. (2008). Detailed geochemistry and K-Ar geochronology of the metamorphic sole rocks and their mafic dykes from the Mersin Ophiolite, Southern Turkey. Turkish Journal of Earth Sciences, 17(4), 685-708.

Çelik, Ö.F., \& Chiaradia, M. (2008). Geochemical and petrological aspects of dike intrusions in the Lycian ophiolites (SW Turkey): a case study for the dike emplacement along the Tauride Belt Ophiolites. International Journal of Earth Sciences, 97(6), 1151-1164.

Çelik, Ö.F., \& Delaloye, M.F. (2003). Origin of metamorphic soles and their post-kinematic mafic dyke swarms in the Antalya and Lycian ophiolites, SW Turkey. Geological Journal, 38 (3-4), 235-256.

Chakraborti, T.M., Ray, A., \& Deb, G.K. (2017). Crystal size distribution analysis of plagioclase from gabbro-anorthosite suite of Kuliana, Orissa, eastern India: Implications for textural coarsening in a static magma chamber. Geological Journal, 52(2), 234-248.

Chiari, M., Djerić, N., Garfagnoli, F., Hrvatović, H., Krstić, M., Levi, N., Malasoma, A., Marroni, M., Menna, F., Nirta, G., \& Pandolfi, L. (2011). The geology of the Zlatibor-Maljen area (western Serbia): a geotraverse across the ophiolites of the Dinaric-Hellenic collisional belt. Ofioliti, 36(2), 139-166.

Claeson, D.T., \& Meurer, W.P. (2004). Fractional crystallization of hydrous basaltic "arc-type" magmas and the formation of amphibole-bearing gabbroic cumulates. Contributions to Mineralogy and Petrology, 147, 288-304.

Compston, W., \& Kröner, A. (1988). Multiple zircon growth with early Archaean tonalitic gneiss from the Ancient Gneiss Complex, Swaziland. Earth Planet. Sci. Lett., 87, 13-28.

Condie, K.C., \& Kröner, A. (2008). When did plate tectonics begin? Evidence from the geological record. In K.C. Condie, \&V. Pease (Eds.). When Did Plate Tectonics Begin on Planet Earth? Geological Society of America, Special Paper, 440, 281-294.

Corfu, F., Armitage, P.E., Kullerud, K., \& Bergh, S.G. (2003). Preliminary U-Pb geochronology in the West Troms Basement Complex, North Norway: Archaean and Palaeoproterozoic events and younger overprints. Norges Geologiske Unders $\phi$ kelse Bulletin, 441, 61-72.

Corkery, M.T., Davis, D.W., \& Lenton, P.G. (1992). Geochronological constraints on the development of the Cross Lake greenstone belt, northwest Superior Province, Manitoba. Canadian Journal of Earth Sciences, 29(10), 2171-2185.

Costa, S., \& Caby, R. (2001). Evolution of the Ligurian Tethys in the Western Alps: Sm/Nd and $\mathrm{U} / \mathrm{Pb}$ geochronology and rare-earth element geochemistry of the Montgenèvre ophiolite (France). Chemical Geology, 175(3-4), 449-466.

Cousens, B.L. (2000). Geochemistry of the Archean Kam Group, Yellowknife greenstone belt, Slave province, Canada. The Journal of Geology, 108(2), 181-197. 
Cox, D., Kerr, A.C., Hastie, A.R., \& Kakar, M.I. (2018). Petrogenesis of plagiogranites in the Muslim Bagh Ophiolite, Pakistan: implications for the generation of Archaean continental crust. Geological Magazine, 156(5), 874-888.

Crawford, A.J. (1989). Boninites and related rocks. Unwin Hyman: London, 496p.

Dai, J., Wang, C., Polat, A., Santosh, M., Li, Y., \& Ge, Y. (2013). Rapid forearc spreading between 130 and 120 Ma: evidence from geochronology and geochemistry of the Xigaze ophiolite, southern Tibet. Lithos, 172, 1-16.

Dantas, E.L., De Souza, Z.S., Wernick, E., Hackspacher, P.C., Martin, H., Xiaodong, D., \& Li, J.W. (2013). Crustal growth in the 3.4-2.7 Ga São José de Campestre Massif, Borborema Province, NE Brazil. Precambrian Research, 227, 120-156.

Dar, A.M., Mir, A.R., Anbarasu, K., Satyanarayanan, M., Balaram, V., Rao, D.S., \& Charan, S.N. (2014). Mafic and ultramafic rocks in parts of the Bhavani complex, Tamil Nadu, Southern India: Geochemistry constraints. Journal of Geology and Mining Research, 6(2), 18-27.

Dearnley, R. (1963). The Lewisian Complex of South Harris. Quarterly Journal of the Geological Society of London, 119, 243-312.

De Graciansky, P.C., Roberts, D.G., \& Tricart, P. (2011). Liguro-piemontais Ophiolites and the Alpine Palaeo-Ocean. In P.C. De Graciansky, D.G. Roberts, \& P. Tricart (Eds.). The Western Alps, from Rift to Passive Margin to Orogenic Belt. Elsevier: Amsterdam, The Netherlands, Developments in Earth Surface Processes, 14, 205-242.

Desmons, J., \& Beccaluva, L. (1983). Mid-ocean ridge and island-arc affinities in ophiolites from Iran: palaeographic implications: complementary reference. Chemical Geology, 39(1-2), 3963.

Devaraju, T.C., Alapieti, T.T., \& Kaukonen, R.J. (2002). Reconnaissance mineralogical and geochemical examination of the late Archaean ultramafic bodies in parts of Shimoga Schist Belt, Karnataka Craton, for discovering evidence of PGE mineralization. In 9th International Platinum Symposium Conferences Papers, 21-25.

Dilek, Y., \& Furnes, H. (2009). Structure and geochemistry of Tethyan ophiolites and their petrogenesis in subduction rollback systems. Lithos, 113(1-2), 1-20.

Dilek, Y., \& Furnes, H. (2011). Ophiolite genesis and global tectonics: Geochemical and tectonic fingerprinting of ancient oceanic lithosphere. Geological Society of America Bulletin, 123 (3/4), 387-411.

Dilek, Y., \& Furnes, H. (2014). Ophiolites and their origins. Elements, 10(2), 93-100.

Dilek, Y., \& Thy, P. (2009). Island arc tholeiite to boninitic melt evolution of the Cretaceous Kizildag (Turkey) ophiolite: model for multi-stage early arc-forearc magmatism in Tethyan subduction factories. Lithos, 113(1-2), 68-87.

Economou-Eliopoulos, M., Eliopoulos, D.G., \& Chryssoulis, S. (2008). A comparison of high-Au massive sulfide ores hosted in ophiolite complexes of the Balkan Peninsula with modern analogues: Genetic significance. Ore Geology Reviews, 33(1), 81-100. 
1010

1011

1012

1013

1014

1015

1016

1017

1018

1019

1020

1021

1022

1023

1024

1025

1026

1027

1028

1029

1030

1031

1032

1033

1034

1035

1036

1037

1038

1039

1040

1041

1042

1043

1044

1045

1046

1047

1048

1049

El Dien, H.G., Doucet, L.S., Murphy, J.B., \& Zheng-Xiang Li, Z.X. (2020). Geochemical evidence for a widespread mantle re-enrichment 3.2 billion years ago: implications for global-scale plate tectonics. Scientific Reports, 10:946, 1-7.

Ermanovics, L.F., \& Davison, W.L. (1976). The Pikwitonei granulites in relation to the northwestern Superior province of the Canadian Shield. In: Windley, B.F. (ed.). The Early History of the Earth. Wiley: London, 331-347.

Elitok, Ö., Özdamar, Ş., Bacak, G., \& Uz, B. (2014). Geological, petrological, and geodynamical characteristics of the Karacaali Magmatic Complex (Kırıkkale) in the Central Anatolian Crystalline Complex, Turkey. Turkish Journal of Earth Sciences, 23(6), 645-667.

Fazlnia, A., Schenk, V., van der Straaten, F., \& Mirmohammadi, M. (2009). Petrology, geochemistry, and geochronology of trondhjemites from the Qori Complex, Neyriz, Iran. Lithos, 112(3-4), 413-433.

Figueiredo, M.D. (1989). Geochemical evolution of eastern Bahia, Brazil: a probable Early Proterozoic subduction-related magmatic arc. Journal of South American Earth Sciences, 2(2), 131-145.

Foley, B.J. (2018). The dependence of planetary tectonics on mantle thermal state: applications to early Earth evolution. Philosophical Transactions of the Royal Society A: Mathematical, Physical and Engineering Sciences, 376(2132), 20170409. http://dx.doi.org/10.1098/rsta.2017.0409.

Foley, B.J., Bercovici, D., \& Elkins-Tanton, L.T. (2014). Initiation of plate tectonics from postmagma ocean thermochemical convection. Journal of Geophysical Research: Solid Earth, 119(11), 8538-8561.

Furnes, H., de Wit, M., \& Dilek, Y. (2014). Four billion years of ophiolites reveal secular trends in oceanic crust formation. Geoscience Frontiers, 5(4), 571-603.

Furnes, H., Dilek, Y., \& de Wit, M. (2015). Precambrian greenstone sequences represent different ophiolite types. Gondwana Research, 27(2), 649-685.

Furnes, H., Dilek, Y., Zhao, G., Safonova, I., \& Santosh, M. (2020). Geochemical characterization of ophiolites in the Alpine-Himalayan Orogenic Belt: Magmatically and tectonically diverse evolution of the Mesozoic Neotethyan oceanic crust. Earth-Science Reviews https://doi.org/10.1016/j.earscirev.2020.103258.

Furnes, H., Robins, B., \& de Wit, M.J. (2012). Geochemistry and petrology of lavas in the upper Onverwacht Suite, Barberton Mountain Land, South Africa. South African Journal of Geology, 115(2), 171-210.

Furnes, H., \& Safonova, I. (2019). Ophiolites of the Central Asian Orogenic Belt: Geochemical and petrological characterization and tectonic settings. Geoscience Frontiers, 10, 1255-1284.

Galoyan, G., Rolland, Y., Sosson, M., Corsini, M., \& Melkonyan, R. (2007). Evidence for superposed MORB, oceanic plateau and volcanic arc series in the Lesser Caucasus (Stepanavan, Armenia). Comptes Rendus Geoscience, 339(7), 482-492.

Galoyan, G., Rolland, Y., Sosson, M., Corsini, M., Billo, S., Verati, C., \& Melkonyan, R. (2009). Geology, geochemistry and ${ }^{40} \mathrm{Ar} /{ }^{39} \mathrm{Ar}$ dating of Sevan ophiolites (Lesser Caucasus, Armenia): 
evidence for Jurassic Back-arc opening and hot spot event between the South Armenian Block and Eurasia. Journal of Asian Earth Sciences, 34(2), 135-153.

Garcia, P.M.D.P., Teixeira, J.B.G., Misi, A., da Silva Sá, J.H., \& da Silva, M.D.G. (2018). Tectonic and metallogenic evolution of the Curaçá Valley Copper Province, Bahia, Brazil: A review based on new SHRIMP zircon $\mathrm{U}-\mathrm{Pb}$ dating and sulfur isotope geochemistry. Ore Geology Reviews, 93, 361-381.

Garde, A.A., \& Hollis, J.A. (2010). A buried Palaeoproterozoic spreading ridge in the northern Nagssugtoqidian orogen, West Greenland. In T.M. Kusky, M.-G. Zhai, \& W. Xiao (Eds.). The Evolving Continents: Understanding Processes of Continental Growth. Geological Society, London, Special Publications, 338, 213-234.

Garde, A.A., \& Steenfelt, A. (1999). Precambrian geology of Nuussuaq and the area north-east of Disko Bugt, West Greenland. Precambrian geology of the Disko Bugt region, West Greenland. Geology of Greenland Survey Bulletin, 181, 6-40.

Garson, M.S., \& Livingstone, A. (1973). Is the South Harris Complex in North Scotland a Precambrian overthrust slice of oceanic crust and island arc? Nature Physical Science, 243(127), 74-76.

Ghazi, A.M., \& Hassanipak, A.A. (2000). Petrology and geochemistry of the Shahr-Babak ophiolite, central Iran. In Y. Dilek, E.M. Moores, D. Elthon, \& A. Nicolas (Eds.). Ophiolites and Oceanic Crust: New Insights from Field Studies and the Ocean Drilling Program. Geological Society of America, Special Paper, 349, 485-497.

Ghazi, A.M., Hassanipak, A.A., Mahoney, J.J., \& Duncan, R.A. (2004). Geochemical characteristics, ${ }^{40} \mathrm{Ar}-{ }^{39} \mathrm{Ar}$ ages and original tectonic setting of the Band-e-Zeyarat/Dar Anar ophiolite, Makran accretionary prism, SE Iran. Tectonophysics, 393(1-4), 175-196.

Ghose, N.C. (2011). Textural Fingerprints of Magmatic, Metamorphic and Sedimentary Rocks Associated with the Naga Hills Ophiolite, Northeast India. In J. Ray, G. Sen, \& B. Ghosh (Eds.). Topics in Igneous Petrology. Springer: Dordrecht, 321-351.

Ghose, N.C., \& Agrawal, O.P. (2010). Microscopic evidence of slab melting at the eastern convergent boundary of the Indian plate: Preliminary report on formation of migmatitic leucocratic granitoid vein in quenched basalt and its bearing on late felsic rocks associated with base metal (Cu-Mo) mineralization in the Naga Hills ophiolite, northeast India. 6th International Dykes Conference, Varanasi, India, Abstracts.

Ghose, N.C., \& Chatterjee, N. (2014). Ophiolite around the Indian Plate margin. In N.C. Ghose, $\&$ N. Chatterjee (Eds.). A Petrographic Atlas of Ophiolite: An example from the eastern IndiaAsia collision zone. Springer: New Delhi, 9-24.

Ghosh, R., Vermeesch, P., Gain, D., \& Mondal, R. (2019). Genetic relationship among komatiites and associated basalts in the Badampahar greenstone Belt (3.25-3.10 Ga), Singhbhum Craton, Eastern India. Precambrian Research, 327, 196-211.

Girelli, T., Chemale Jr, F., Lavina, E.L.C., Laux, J.H., Bongiolo, E., \& Lana, C. (2016). Proterozoic evolution of Santa Maria Chico Granulitic Complex and adjacent areas. In: $8^{\text {th }}$ Congresso Brasileiro de Geologia, 48, 5p. 
Golestani, M. (2013). Petrology, Geochemistry and Tectonic Setting Intrusive Massives of Baft Ophiolitic - Melange, Southeast of Kerman, Iran. Journal of Tethys, 3, 164-176.

Golowin, R., Portnyagin, M., Hoernle, K., Sobolev, A., Kuzmin, D., \& Werner, R. (2017). The role and conditions of second-stage mantle melting in the generation of low-Ti tholeiites and boninites: the case of the Manihiki Plateau and the Troodos ophiolite. Contributions to Mineralogy and Petrology, 172(11-12): 104.

Good, D., Mealin, C., \& Walford, P. (2009). Geology of the Ore Fault Ni-Cu Deposit, Bird River Sill Complex, Manitoba. Exploration and Mining Geology, 18(1-4), 41-57.

Goodenough, K.M., Styles, M.T., Schofield, D., Thomas, R.J., Crowley, Q.C., Lilly, R.M., McKervey, J., Stephenson, D., \& Carney, J.N. (2010). Architecture of the Oman-UAE ophiolite: evidence for multi-phase magmatic history. Arabian Journal of Geosciences, 3, 439458.

Goodenough, K.M., Thomas, R.J., Styles, M.T., Schofield, D.I., \& MacLeod, C.J. (2014). Records of ocean growth and destruction in the Oman-UAE ophiolite. Elements, 10(2), 109-114.

Guo, M., \& Korenaga, J. (2020). Argon constraints on the early growth of felsic continental crust. Science Advances, 6: eaaz6234, 1-10.

Haggerty S.E., Hills D.V., \& Toft P.B. (1988). Crustal evolution and the eclogite to granulite phase transition in xenoliths from the West African craton. In L.D. Ashwal (Ed.). Workshop on the growth of continental crust. Lunar and Planetary Institute: Houston, Technical Report, 88-02, 68-70.

Hartlaub, R.P., Böhm, C.O., Kuiper, Y.D., Bowerman, M.S., \& Heaman, L.M. (2004a). Archean and Paleoproterozoic geology of the northwestern Split Lake Block, Superior Province, Manitoba (parts of NTS 54D4, 5, 6 and 64A1). In Report of Field Activities 2004. Manitoba Industry, Economic Development and Mines, Manitoba Geological Survey, 187-194.

Hartlaub, R.P., Heaman, L.M., Ashton, K.E., \& Chacko, T. (2004b). The Archean Murmac Bay Group: evidence for a giant archean rift in the Rae Province, Canada. Precambrian Research, 131(3-4), 345-372.

Hartlaub, R.P., \& Kuiper. Y.D. (2004). Geology of central and north Split Lake (parts of NTS 54D4, 5 and 64A1, 8), Manitoba. Manitoba Industry, Economic Development and Mines, Manitoba Geological Survey, Preliminary Map PMAP2004-1, scale 1:25000.

Hassanipak, A.A., \& Ghazi, A.M. (2000). Petrology, geochemistry and tectonic setting of the Khoy ophiolite, northwest Iran: implications for Tethyan tectonics. Journal of Asian Earth Sciences, 18(1), 109-121.

Hastie, A.R., \& Fitton, J.G. (2019). Eoarchean tectonics: New constraints from high pressuretemperature experiments and mass balance modelling. Precambrian Research, 325, 20-38.

Haugaard, R., Frei, R., Stendal, H., \& Konhauser, K. (2013). Petrology and geochemistry of the $\sim 2.9 \mathrm{Ga}$ Itilliarsuk banded iron formation and associated supracrustal rocks, West Greenland: Source characteristics and depositional environment. Precambrian Research, 229, 150-176.

Hébert, R., Bezard, R., Guilmette, C., Dostal, J., Wang, C.S., \& Liu, Z.F. (2012). The IndusYarlung Zangbo ophiolites from Nanga Parbat to Namche Barwa syntaxes, southern Tibet: 
First synthesis of petrology, geochemistry, and geochronology with incidences on geodynamic reconstructions of Neo-Tethys. Gondwana Research, 22(2), 377-397.

Herz, N., \& Savu, H. (1974). Plate tectonics history of Romania. Geological Society of America Bulletin, 85(9), 1429-1440.

Hoatson, D.M., \& Sun, S.S. (2002). Archean layered mafic-ultramafic intrusions in the west Pilbara craton, Western Australia: a synthesis of some of the oldest orthomagmatic mineralizing systems in the world. Economic Geology, 97(4), 847-872.

Hoeck, V., Koller, F., Meisel, T., Onuzi, K., \& Kneringer, E. (2002). The Jurassic South Albanian ophiolites: MOR-vs. SSZ-type ophiolites. Lithos, 65(1-2), 143-164.

Hoffmann, J.E., Kröner, A., Hegner, E., Viehmann, S., Xie, H., Iaccheri, L.M., Schneider, K.P., Hofmann, A., Wong, J., Geng, H., \& Yang, J. (2016). Source composition, fractional crystallization and magma mixing processes in the 3.48-3.43 Ga Tsawela tonalite suite (Ancient Gneiss Complex, Swaziland) - implications for Palaeoarchaean geodynamics. Precambrian Research, 276, 43-66.

Hoffmann, J.E., Svahnberg, H., Piazolo, S., Scherstén, A., \& Münker, C. (2012). The geodynamic evolution of Mesoarchean anorthosite complexes inferred from the Naajat Kuuat Complex, southern West Greenland. Precambrian Research, 196, 149-170.

Houlé, M.G., Lesher, C.M., McNicoll, V.J., Metsaranta, R.T., Sappin, A.-A., Goutier, J., Bécu, V., Gilbert, H.P., \& Yang, X.M. (2015). Temporal and spatial distribution of magmatic Cr(PGE), Ni-Cu-(PGE), and Fe-Ti-(V) deposits in the Bird River-Uchi-Oxford-Stull-La Grande Rivière-Eastmain domains: a new metallogenic province within the Superior Craton. In D.E. Ames \& M.G. Houlé (Eds.). Targeted Geoscience Initiative 4: Canadian Nickel-CopperPlatinum Group Elements-Chromium Ore Systems - Fertility, Pathfinders, New and Revised Models. Geological Survey of Canada, Open File, 7856, 35-48.

Huang, H., Fryer, B.J., Polat, A., \& Pan, Y. (2014). Amphibole, plagioclase and clinopyroxene geochemistry of the Archean Fiskenæsset Complex at Majorqap qâva, southwestern Greenland: implications for Archean petrogenetic and geodynamic processes. Precambrian Research, 247, 64-91.

Hughes, H.S., McDonald, I., Goodenough, K.M., Ciborowski, T.J.R., Kerr, A.C., Davies, J.H., \& Selby, D. (2014). Enriched lithospheric mantle keel below the Scottish margin of the North Atlantic Craton: Evidence from the Palaeoproterozoic Scourie Dyke Swarm and mantle xenoliths. Precambrian Research, 250, 97-126.

Hunter, D.R., Barker, F., \& Millard Jr., H.T. (1978). The geochemical nature of the Archean Ancient Gneiss Complex and Granodiorite Suite, Swaziland: A preliminary study. Precambrian Research, 7, 105-127.

Iizuka, T., Komiya, T., Ueno, Y., Katayama, I., Uehara, Y., Maruyama, S., Hirata, T., Johnson, S.P., \& Dunkley, D.J. (2007). Geology and zircon geochronology of the Acasta Gneiss Complex, northwestern Canada: new constraints on its tectonothermal history. Precambrian Research, 153(3-4), 179-208.

Isachsen, C.E., \& Bowring, S.A. (1994). Evolution of the Slave craton. Geology, 22(10), 917-920. 
Ishizuka, H. (2008). Protoliths of the Napier Complex in Enderby Land, East Antarctica; an overview and implication for crustal formation of Archaean continents. Journal of Mineralogical and Petrological Sciences, 103(4), 218-225.

Ishizuka, O., Tani, K., \& Reagan, M.K. (2014). Izu-Bonin-Mariana forearc crust as a modern ophiolite analogue. Elements, 10(2), 115-120.

Ivanic, T.J., Wingate, M.T.D., Kirkland, C.L., Van Kranendonk, M.J., \& Wyche, S. (2010). Age and significance of voluminous mafic-ultramafic magmatic events in the Murchison Domain, Yilgarn Craton. Australian Journal of Earth Sciences, 57(5), 597-614.

Jackson, M.P.A. (1984). Archaean structural styles in the Ancient Gneiss Complex of Swaziland, South Africa. In: Kröner, A. \& Greiling, R. (Eds.). Precambrian Tectonic Illustrated. Schweizerbart'sche Verlagsbuchhandlung: Stuttgart, 1-18.

Jafari, M.K., Babaie, H.A., \& Moslempour, M.E. (2017). Mid-ocean-ridge to suprasubduction geochemical transition in the hypabyssal and extrusive sequences of major Upper Cretaceous ophiolites of Iran. Tectonic Evolution, Collision, and Seismicity of Southwest Asia: In Honor of Manuel Berberian's Forty-Five Years of Research Contributions, 525, 229-290.

Jagoutz, O., Müntener, O., Burg, J.P., Ulmer, P., \& Jagoutz, E. (2006). Lower continental crust formation through focused flow in km-scale melt conduits: The zoned ultramafic bodies of the Chilas Complex in the Kohistan island arc (NW Pakistan). Earth and Planetary Science Letters, 242(3-4), 320-342.

Jagoutz, O., Müntener, O., Ulmer, P., Pettke, T., Burg, J.P., Dawood, H., \& Hussain, S. (2007). Petrology and mineral chemistry of lower crustal intrusions: the Chilas Complex, Kohistan (NW Pakistan). Journal of Petrology, 48(10), 1895-1953.

James, D.T., Kamo, S., \& Krogh, T. (2002). Evolution of 3.1 and 3.0 Ga volcanic belts and a new thermotectonic model for the Hopedale Block, North Atlantic craton (Canada). Canadian Journal of Earth Sciences, 39(5), 687-710.

Jan, M.Q., Khan, M.A., \&Qazi, M.S. (1993). The Sapat mafic-ultramafic complex, Kohistan arc, North Pakistan. Geological Society, London, Special Publications, 74(1), 113-121.

Jian, P., Kröner, A., Windley, B.F., Shi, Y., Zhang, W., Zhang, L., \& Yang, W. (2012). Carboniferous and Cretaceous mafic-ultramafic massifs in Inner Mongolia (China): a SHRIMP zircon and geochemical study of the previously presumed integral "Hegenshan ophiolite". Lithos, 142, 48-66.

Jian, P., Liu, D., Kröner, A., Zhang, Q., Wang, Y., \& Sun, X., W. (2009). Devonian to Permian plate tectonic cycle of the Paleo-Tethys Orogen in southwest China (I): geochemistry of ophiolites, arc/back-arc assemblages and within-plate igneous rocks. Lithos, 113(3-4), 748766.

Jian, P., Liu, D., \& Sun, X. (2008). SHRIMP dating of the Permo-Carboniferous Jinshajiang ophiolite, southwestern China: Geochronological constraints for the evolution of Paleo-Tethys. Journal of Asian Earth Sciences, 32(5-6), 371-384.

Jian, P., Wang, X., He, L., \& Wang, C. (1999). U-Pb zircon dating of anorthosite and plagiogranite from the Jingshajiang ophiolite belt. Acta Petrologica Sinica, 15, 590-593. 
Jobin-Bevans, L.S. (1997). Geology, mineral chemistry and petrogenesis of the Pipestone Lake anorthosite complex. University of Manitoba, Winnipeg, Manitoba, M.Sc. thesis, 269p.

Kakar, M.I., Kerr, A.C., Mahmood, K., Collins, A.S., Khan, M., \& McDonald, I. (2014). Suprasubduction zone tectonic setting of the Muslim Bagh ophiolite, northwestern Pakistan: Insights from geochemistry and petrology. Lithos, 202, 190-206.

Kapsiotis, A., Economou-Eliopoulos, M., Zheng, H., Su, B.X., Lenaz, D., Jing, J.J., Antonelou, A., Velicogna, M., \& Xia, B. (2019). Refractory chromitites recovered from the Eretria mine, East Othris massif (Greece): Implications for metallogeny and deformation of chromitites within the lithospheric mantle portion of a forearc-type ophiolite. Geochemistry, doi.org/10.1016/j.geoch.2018.12.003.

Keeditse, M. (2016). Evidence for arc-related origin of a Mesoarchean layered ultramafic-mafic intrusion from Limpopo Complex, southern Africa. Goldschmidt Conference Abstracts, p. 1471.

Khan, M.A., Jan, M.Q., Windley, B.F., Tarney, J., Thirlwall, M.F. (1989). The Chilas maficultramafic igneous complex; the root of the Kohistan island arc in the Himalaya of northern Pakistan. In L.L. Malinconico Jr., \&R.J. Lillie (Eds.). Tectonics of the western Himalayas. Geological Society of America, Special Paper, 232, 75-94.

Khan, M., Khan, M.J., Kakar, M.I., \& Mehmud, K. (2018). Geology and Tectonic Setting of Nal Ophiolite, District Khuzdar, Balochistan, Pakistan. American Journal of Earth and Environmental Sciences, 1(3), 115-123.

Khalatbari-Jafari, M., Juteau, T., Bellon, H., \& Emami, H. (2003). Discovery of two ophiolite complexes of different ages in the Khoy area (NW Iran). Comptes Rendus Geoscience, 335(12), 917-929.

Khalatbari-Jafari, M., Juteau, T., \& Cotten, J. (2006). Petrological and geochemical study of the Late Cretaceous ophiolite of Khoy (NW Iran), and related geological formations. Journal of Asian Earth Sciences, 27(4), 465-502.

Komiya, T., Yamamoto, S., Aoki, S., Sawaki, Y., Ishikawa, A., Tashiro, T., Koshida, K., Shimojo, M., Aoki, K., \& Collerson, K.D. (2015). Geology of the Eoarchean, > 3.95 Ga, Nulliak supracrustal rocks in the Saglek Block, northern Labrador, Canada: The oldest geological evidence for plate tectonics. Tectonophysics, 662, 40-66.

Koshida, K., Ishikawa, A., Iwamori, H., \& Komiya, T., 2016. Petrology and geochemistry of mafic rocks in the Acasta Gneiss Complex: Implications for the oldest mafic rocks and their origin. Precambrian Research, 283, 190-207.

Kröner, A., \& Tegtmeyer, A. (1994). Gneiss-greenstone relationships in the Ancient Gneiss Complex of southwestern Swaziland, southern Africa, and implications for early crustal evolution. Precambrian Research, 67(1-2), 109-139.

Kudryashov, N.M., \& Mokrushin, A.V. (2011). Mesoarchean gabbroanorthosite magmatism of the Kola Region: petrochemical, geochronological, and isotope-geochemical data. Petrology, 19(2), 167-182. 
Kunugiza, K., Kato, Y., Kano, T., Takaba, Y., Kuruma, I., \& Sohma, T. (1996). An Archaean tectonic model of the Dharwar craton, southern India: the origin of the Holenarasipur greenstone belt (Hussan district, Karnataka) and reinterpretation of the Sargur-Dharwar relationship. Journal of Southeast Asian Earth Sciences, 14(3-4), 149-160.

Kusky, T.M., Windley, B.F., \& Polat, A. (2018). Geological evidence for the operation of plate tectonics throughout the Archean: Records from Archean paleo-plate boundaries. Journal of Earth Science, 29(6), 1291-1303.

Kutty, T.R.N., Iyer, G.A., Ramakrishnan, M., \&Verma, S.P. (1984). Geochemistry of metaanorthosites from Holénarasipur, Karnataka, South India. Lithos, 17, 317-328.

Kuzmich, B.N. (2014). Petrogenesis of the ferrogabbroic intrusions and associated Fe-Ti--V-P mineralization within the McFaulds greenstone belt, Superior Province, Canada. Lakehead University: Thunder Bay, Canada, M.Sc. thesis, 496p.

Kuzmich, B., Hollings, P., \& Houlé, M.G. (2015). Petrogenesis of the ferrogabbroic intrusions and associated Fe-Ti-V-(P) mineralization within the McFaulds greenstone belt, Superior Province, northern Ontario, In D.E. Ames, M.G. Houlé (Eds.). Targeted Geoscience Initiative 4: Canadian Nickel-Copper-Platinum Group Elements-Chromium Ore Systems - Fertility, Pathfinders, New and Revised Models. Geological Survey of Canada, Open File, 7856, 115123.

Laarman, J.E. (2013). A detailed metallogenic study of the McFaulds Lake chromite deposits, northern Ontario. University of Western Ontario: London, Ontario, Canada, Ph.D. thesis, 494p.

Larin, A.M. (2009). Rapakivi granites in the geological history of the earth. Part 1, magmatic associations with rapakivi granites: age, geochemistry, and tectonic setting. Stratigraphy and Geological Correlation, 17(3), 235-258.

Larin, A.M., Kotov, A.B., Sal'nikova, E.B., Glebovitskii, V.A., Sukhanov, M.K., Yakovleva, S.Z., Kovach, V.P., Berezhnaya, N.G., Velikoslavinskii, S.D., \& Tolkachev, M.D. (2006). The Kalar Compex, Aldan-Stanovoi shield, an ancient anorthosite-mangerite-charnockite-granite association: Geochronologic, geochemical, and isotopic-geochemical characteristics. Petrology, 14(1), 2-20.

Latypov, R., Chistyakova, S., Costin, G., Namur, O., Barnes, S., \& Kruger, W. (2020). Monomineralic anorthosites in layered intrusions are indicators of the magma chamber replenishment by plagioclase-only-saturated melts. Scientific Reports, 10:3839, https://doi.org/10.1038/s41598-020-60778-w.

Leake, B.E., Woolley, A.R., Arps, C.E.S., Birch, W.D., Gilbert, M.C., Grice, J.D., Hawthorne, F.C., Kato, A., Kisch, H.J., Krivovichev, V.G., Linthout, K., Laird, J., Mandarino, J.A., Maresch, W.V., Nickel, E.H., Rock, N.M.S., Schumacher, J.C., Smith, D.C., Stephenson, N.C.N., Ungaretti, L., Whittaker, E.J.W., \& Youzhi, G. (1997). Nomenclature of amphiboles: Report of the subcommittee on amphiboles of the International Mineralogical Association, Commission on New Minerals and Mineral Names. The Canadian Mineralogist, 35, 219-246. Leatherdale, S.M., Maxeiner, R.O., \& Ansdell, K.M. (2003). Petrography and geochemistry of the Love Lake Leucogabbro, Swan River Complex, Peter Lake Domain, northern Saskatchewan. 
In Summary of Investigations 2003, Volume 2. Saskatchewan Geological Survey, Saskatchewan. Industry Resources, Misc. Rep. 2003-4.2, CD-ROM, Paper A-8, 17p.

Liu, H., Sun, W.D., \& Deng, J. (2020). Statistical analysis on secular records of igneous geochemistry: Implication for the early Archean plate tectonics. Geological Journal, 55, 9941002.

Liu, T., Zhai, Q.-G., Wang, J., Bao, P.-S., Qiangba, Z., Tang, S.-H., \& Tang, Y. (2016). Tectonic significance of the Donqqiao ophiolite in the north-central Tibetan plateau: Evidence from zircon dating, petrological, geochemical and Sr-Nd-Hf isotopic characterization. Journal of Asian Earth Sciences, 116, 139-154.

Lu, H., Jia, D., Wang, Z., Guo, L., Shi, Y., \& Zhang, Q. (1994). Tectonic evolution of the Dongshan terrane, Fujian province, China. Journal of South American Earth Sciences, 7(3-4), 349-365.

Maier, W.D., Barnes, S.J., Gartz, V., \& Andrews, G. (2003). Pt-Pd reefs in magnetitites of the Stella layered intrusion, South Africa: A world of new exploration opportunities for platinum group elements. Geology, 31(10), 885-888.

Maier, W.D., \& Groves, D.I. (2011). Temporal and spatial controls on the formation of magmatic PGE and Ni-Cu deposits. Mineralium Deposita, 46(8), 841-857.

Marroni, M., \& Tribuzio, R. (1996). Gabbro-derived granulites from External Liguride units (northern Apennine, Italy): implications for the rifting processes in the western Tethys. Geologische Rundschau, 85(2), 239-249.

Maruyama, S., Kawai, T., \& Windley, B.F. (2010). Ocean plate stratigraphy and its imbrication in an accretionary orogen: the Mona Complex, Anglesey-Lleyn, Wales, UK. In T.M. Kusky, M.G. Zhai, \& W. Xiao (Eds.). The Evolving Continents: Understanding Processes of Continental Growth. Geological Society, London, Special Publications, 338, 55-75.

Mathieu, L. (2019). Origin of the Vanadiferous Serpentine-Magnetite Rocks of the Mt. Sorcerer Area, Lac Doré Layered Intrusion, Chibougamau, Québec. Geosciences, 9(3), 110. doi:10.3390/geosciences9030110.

Mealin, C.A., Linnen, R.L., Lin, S., Theyer, P., \& Corkery, P.T. (2013). Bird River Intrusive Complex in the western Superior Province, Manitoba: Evidence for a conduit model and controls on Ni-Cu-PGE and Cr mineralization (abstract). Geological Association of CanadaMineralogical Association Joint Meeting, 36, Program Abstracts, p.143.

Mechati, M., Caby, R., Hammor, D., Bosch, D., Bruguier, O., \& Fernandez, L. (2018). Reworking of intra-oceanic rocks in a deep sea basin: example from the Bou-Maiza complex (Edough massif, eastern Algeria). International Geology Review, 60(4), 464-478.

Menzies, M. (1973). Mineralogy and partial melt textures within an ultramafic-mafic body, Greece. Contributions to Mineralogy and Petrology, 42(4), 273-285.

Metsaranta, R.T., Houlé, M.G., McNicoll, V.J., \& Kamo, S.L. (2015). Revised geological framework for the McFaulds Lake greenstone belt, Ontario, In: D.E. Ames, M.G. Houlé (Eds.). Targeted Geoscience Initiative 4: Canadian Nickel-Copper-Platinum Group Elements- 
Chromium Ore Systems - Fertility, Pathfinders, New and Revised Models. Geological Survey of Canada, Open File, 7856, 61-73.

Miao, L., Fan, W., Liu, D., Zhang, F., Shi, Y., \& Guo, F. (2008). Geochronology and geochemistry of the Hegenshan ophiolitic complex: Implications for late-stage tectonic evolution of the Inner Mongolia-Daxinganling Orogenic Belt, China. Journal of Asian Earth Sciences, 32(5-6), 348370.

Mitsis, I., \& Economou-Eliopoulos, M. (2001). Occurrence of apatite associated with magnetite in an ophiolite complex (Othrys), Greece. American Mineralogist, 86(10), 1143-1150.

Moghadam, H.S., \& Stern, R.J. (2015). Ophiolites of Iran: Keys to understanding the tectonic evolution of SW Asia:(II) Mesozoic ophiolites. Journal of Asian Earth Sciences, 100, 31-59.

Moghadam, H.S., Zaki Khedr, M., Chiaradia, M., Stern, R.J., Bakhshizad, F., Arai, S., Ottley, C.J., \& Tamura, A. (2014). Supra-subduction zone magmatism of the Neyriz ophiolite, Iran: constraints from geochemistry and $\mathrm{Sr}-\mathrm{Nd}-\mathrm{Pb}$ isotopes. International Geology Review, 56(11), 1395-1412.

Mohammad, Y., Kareem, H., \& Anma, R. (2016). The Kuradawe Granitic Pegmatite from the Mawat Ophiolite, Northeastern Iraq: Anatomy, Mineralogy, Geochemistry, and Petrogenesis. The Canadian Mineralogist, 54(4), 989-1019.

Mohan, M.R., Satyanarayanan, M., Santosh, M., Sylvester, P.J., Tubrett, M., \& Lam, R. (2013). Neoarchean suprasubduction zone arc magmatism in southern India: Geochemistry, zircon U$\mathrm{Pb}$ geochronology and $\mathrm{Hf}$ isotopes of the Sittampundi Anorthosite Complex. Gondwana Research, 23(2), 539-557.

Mondal, S.K., \& Zhou, M.F. (2010). Enrichment of PGE through interaction of evolved boninitic magmas with early formed cumulates in a gabbro-breccia zone of the Mesoarchean Nuasahi massif (eastern India). Mineralium Deposita, 45(1), 69-91.

Moore, M., Davis, D.W., Robb, L.J., Jackson, M.C., \& Grobler, D.F. (1993). Archean rapakivi granite-anorthosite-rhyolite complex in the Witwatersrand basin hinterland, southern Africa. Geology, 21, 1031-1034.

Morris, A., Anderson, M.W., Omer, A., Maffione, M., \& van Hinsbergen, D.J.J. (2017). Rapid fore-arc extension and detachment-mode spreading following subduction initiation. Earth and Planetary Science Letters, 478, 76-88.

Morrison, D.A., Haskin, L.A., Qiu, Y.Z., Phinney, W.C., \& Maczuga, D.E. (1985). Alteration in Archean anorthosite complexes. Lunar Planet. Inst.: Houston, Lunar and Planet. Sci. XVI., 589-590.

Motuza, G., Motuza, V., Beliatsky, B., \& Savva, E. (2001a). Volcanic rocks of the Ringvassoya greenstone belt (North Norway): Implication for the stratigraphy and tectonic setting (Abstract). EUG XI 6 (1) Conference Abstracts, p. 578.

Motuza, G., Motuza, V., Beliatsky, B., \& Savva, E. (2001b). The Ringvassoya greenstone belt (Tromso, North Norway): implications for a Mesoarchaean subduction zone (Abstract). EUROPROBE time-slice symposium “Archaean and Proterozoic Plate Tectonics: Geological and Geophysical Records: St. Petersburg, Russia, October 1-November 3, 2001, 43-44. 
Mouri, H., Whitehouse, M.J., Brandl, G., \& Rajesh, H.M. (2009). A magmatic age and four successive metamorphic events recorded in zircons from a single meta-anorthosite sample in the Central Zone of the Limpopo Belt, South Africa. Journal of the Geological Society, 166(5), 827-830.

Mukherjee, A., \& Das, S. (2002). Anorthosites, granulites and the supercontinent cycle. Gondwana Research, 5(1), 147-156.

Mukherjee, R., Mondal, S.K., Rosing, M.T., \& Frei, R. (2010). Compositional variations in the Mesoarchean chromites of the Nuggihalli schist belt, Western Dharwar Craton (India): potential parental melts and implications for tectonic setting. Contributions to Mineralogy and Petrology, 160(6), 865-885.

Murphy, J.B. (2007). Igneous Rock Associations 8. Arc magmatism II: Geochemical and isotopic characteristics. Geoscience Canada, 34(1), 7-35.

Myers, J.S. (1976). Granitoid sheets, thrusting, and Archean crustal thickening in West Greenland. Geology, 4, 265-268.

Myers, J.S. (1985). Stratigraphy and structure of the Fiskenæsset complex, southern West Greenland. Grønland Geologiske Undersøgelse Bulletin, 150, 72 pp.

Myers, J.S. (1988). Oldest known terrestrial anorthosite at Mount Narryer, Western Australia. Precambrian Research, 38(4), 309-323.

Naqvi, S.M., \& Hussain, S.M. (1979). Geochemistry of metaanorthosites from a greenstone belt in Karnataka, India. Canadian Journal of Earth Sciences, 16, 1254-1264.

Naqvi, S.M., \& Prathap, J.R. (2007). Geochemistry of adakites from Neoarchaean active continental margin of Shimoga schist belt, Western Dharwar craton, India: Implications for the genesis of TTG. Precambrian Research, 156(1-2), 32-54.

Nurlu, N., Türkmen, S., Şimşek, G., \& Stepanov, A.S. (2018). Geochemistry and zircon U-Pb geochronology constrains Late Cretaceous plagiogranite intrusions in Mersin ophiolite complex (southern Turkey). Arabian Journal of Geosciences, 11, 745, doi: 10.1007/s12517018-4120-3.

Nutman, A.P., Bennett, V.C., Friend, C.R., Jenner, F., Wan, Y., \& Liu, D. (2009). Eoarchaean crustal growth in West Greenland (Itsaq Gneiss Complex) and in northeastern China (Anshan area): review and synthesis. In P.A. Cawood, \& A. Kröner (Eds.). Earth Accretionary Systems in Space and Time. Geological Society, London, Special Publications, 318(1), 127-154.

Nutman, A.P., Bennett, V.C., Friend, C.R.L., \& Yi, K. (2020). Eoarchean contrasting ultra-highpressure to low-pressure metamorphisms $\left(<250\right.$ to $\left.>1000{ }^{\circ} \mathrm{C} / \mathrm{GPa}\right)$ explained by tectonic plate convergence in deep Time. Precambrian Research, $\underline{344}, 105770$.

Okay, A. İ., \& Tüysüz, O. (1999). Tethyan sutures of northern Turkey. In B. Durand, L. Jolivet, F. Horváth, \& M. Séranne (Eds.). The Mediterranean Basins: Tertiary Extension Within the Alpine Orogen. Geological Society, London, Special Publications, 156, 475-515.

O'Neil, J., Maurice, C., Stevenson, R.K., Larocque, J., Cloquet, C., David, J., \& Francis, D. (2007). The geology of the $3.8 \mathrm{Ga}$ Nuvvuagittuq (Porpoise Cove) greenstone belt, northeastern 

Superior Province. In M.J. Van Kranendonk, R.H. Smithies, \& V. Bennett (Eds.). Earth's Oldest Rocks. Elsevier: Amsterdam, Developments in Precambrian Geology, 15, 219-254. Ordóñez-Calderón, J.C., Polat, A., Fryer, B.J., Appel, P.W.U., van Gool, J.A.M., Dilek, Y., \& Gagnon, J.E. (2009). Geochemistry and geodynamic origin of the Mesoarchean Ujarassuit and Ivisaartoq greenstone belts, SW Greenland. Lithos, 113(1), 133-157.

Ordóñez-Calderón, J.C., Polat, A., Fryer, B.J., \& Gagnon, J.E. (2011). Field and geochemical characteristics of Mesoarchean to Neoarchean volcanic rocks in the Storø greenstone belt, SW Greenland: evidence for accretion of intra-oceanic volcanic arcs. Precambrian Research, 184(1), 24-42.

Paixão, M.A.P., \& Oliveira, E.P. (1998). The Lagoa da Vaca complex: an Archaean layered anorthosite body on the western edge of the Uauá Block, Bahia, Brazil. Revista Brasileira de Geociencias, 28(2), 201-208.

Pamić, J., Tomljenović, B., \& Balen, D. (2002). Geodynamic and petrogenetic evolution of Alpine ophiolites from the central and NW Dinarides: an overview. Lithos, 65(1-2), 113-142.

Parlak, O., Bağc1, U., Rızaoğlu, T., Ionescu, C., Önal, G., Höck, V., \& Kozlu, H. (2019). Petrology of ultramafic to mafic cumulate rocks from the Göksun (Kahramanmaraş) ophiolite, southeast Turkey. Geoscience Frontiers, https://doi.org/10.1016/j.gsf.2018.11.004.

Parlak, O., Çolakoğlu, A., Dönmez, C., Sayak, H., Yildirim, N., Türkel, A., \& Odabaşi, İ. (2013a). Geochemistry and tectonic significance of ophiolites along the İzmir-Ankara-Erzincan Suture Zone in northeastern Anatolia. Geological Society, London, Special Publications, 372(1), 75105.

Parlak, O., Delaloye, M., \& Bíngöl, E. (1996). Mineral chemistry of ultramafic and mafic cumulates as an indicator of the arc-related origin of the Mersin ophiolite (southern Turkey). Geologische Rundschau, 85(4), 647-661.

Parlak, O., Karaoğlan, F., Rizaoğlu, T., Nurlu, N., Bağci, U., Höck, V., Önal, A.Ö., Kürüm, S., \& Topak, Y. (2013b). Petrology of the İspendere (Malatya) ophiolite from the Southeast Anatolia: Implications for the Late Mesozoic evolution of the southern Neotethyan ocean. Geological Society, London, Special Publications, 372(1), 219-247.

Pearce, J.A., \& Peate, D.W. (1995). Tectonic implications of the composition of volcanic arc magmas. Annual Review of Earth and Planetary Sciences, 23, 251-286.

Pearce, J.A. (2008). Geochemical fingerprinting of oceanic basalts with applications to ophiolite classification and the search for Archean oceanic crust. Lithos, 100, 14-48.

Pearce, J.A. (2014). Immobile Element Fingerprinting of Ophiolites. Elements, 10(2), 101-108.

Pease, V., Percival, J., Smithies, H., Stevens, G., \& Van Kranendonk, M. (2008). When did plate tectonics begin? Evidence from the orogenic record. In K.C. Condie, \& V. Pease (Eds.). When Did Plate Tectonic Begin On Planet Earth? The Geological Society of America, Special Paper, 440, 199-228.

Peck, D.C., Halden, N.M., Jobin-Bevans, S., Cameron, H.D.M., \& Theyer, P. (1999a). Summary of metallogenetic and petrogenetic features of Archean anorthosites and associated mafic and 
ultramafic rocks in the Superior Province, Manitoba (parts of NTS 63I, 63J, 63P and 64A). In Report of Activities 1999. Manitoba Industry, Trade and Mines, Geological Services, 94-96.

Peck, D.C., Messing, C., Halden, N.M., \& Chandler, C. (1998). New insights into the petrogenesis of the Pipestone Lake anorthosite complex and its Ti-V-Fe oxide deposits (parts of NTS 63I/5 and I/12). In Report of Activities 1998. Manitoba Energy and Mines, Geological Services, 127134.

Peng, E., \& Zhu, Y. (1996). Petrochemistry on the Animaqen ophiolite. Journal of Central South University of Technology, 3(1), 34-36.

Pe-Piper, G., Tsikouras, B., \& Hatzipanagiotou, K. (2004). Evolution of boninites and island-arc tholeiites in the Pindos Ophiolite, Greece. Geological Magazine, 141(4), 455-469.

Petersson, A., Kemp, A.I., Hickman, A.H., Whitehouse, M.J., Martin, L., \& Gray, C.M. (2019). A new 3.59 Ga magmatic suite and a chondritic source to the east Pilbara Craton. Chemical Geology, 511, 51-70.

Petterson, M.G. (2018). The plutonic crust of Kohistan and volcanic crust of Kohistan-Ladakh, north Pakistan/India: lessons learned for deep and shallow arc processes. Geological Society, London, Special Publications, 483, SP483-4.

Phinney, W.C., Morrison, D.A., \& Maczuga, D.E. (1988). Tectonic implications of anorthosite occurrences. Lunar Planet. Inst.: Houston, Lunar Planet. Inst. Tech. Rep., 88-06, 135-137.

Piaia, P., Oliveira, E.P., \& Valeriano, C.M. (2017). The 2.58 Ga São José do Jacuipe gabbroanorthosite stratiform complex, Itabuna-Salvador-Curaçá Orogen, São Francisco Craton, Brazil: Root of the Neoarchaean Caraiba continental arc? Journal of South American Earth Sciences, 79, 326-341.

Piccardo, G.B., \& Guarnieri, L. (2011). Gabbro-norite cumulates from strongly depleted MORB melts in the Alpine-Apennine ophiolites. Lithos, 124(3-4), 200-214.

Polat, A., Appel, P.W.U., Fryer, B., Windley, B., Frei, R., Samson, I.M., \& Huang, H. (2009). Trace element systematics of the Neoarchean Fiskenæsset anorthosite complex and associated meta-volcanic rocks, SW Greenland: Evidence for a magmatic arc origin. Precambrian Research, 175, 87-115.

Polat, A., Frei, R., Appel, P.W.U., Dilek, Y., Fryer, B., Ordóñez-Calderón, J.C., \& Yang, Z. (2008a). The origin and compositions of Mesoarchean oceanic crust: evidence from the 3075 Ma Ivisaartoq greenstone belt, SW Greenland. Lithos, 100(1), 293-321.

Polat, A., Frei, R., Appel, P.W., Fryer, B., Dilek, Y., \& Ordóñez-Calderón, J.C. (2008b). An overview of the lithological and geochemical characteristics of the Mesoarchean (ca. $3075 \mathrm{Ma}$ ) Ivisaartoq greenstone belt, southern West Greenland. In K.C. Condie, \& V. Pease (Eds.). When Did Plate Tectonics Begin On Planet Earth? The Geological Society of America, Special Paper, 440, 51-76.

Polat, A., Frei, R., Longstaffe, F.J., \& Woods, R. (2018b). Petrogenetic and geodynamic origin of the Neoarchean Doré Lake Complex, Abitibi subprovince, Superior Province, Canada. International Journal of Earth Sciences (Geol Rundsch), 107(3), 811-843. 
Polat, A., Frei, R, Scherstén, A., \& Appel, P. W.U. (2010). New age (ca. 2970 Ma), mantle source composition and geodynamic constraints on the Archean Fiskenæsset anorthosite complex, SW Greenland. Chemical Geology, 277, 1-20.

Polat, A., Fryer, B.J., Appel, P.W., Kalvig, P., Kerrich, R., Dilek, Y., \& Yang, Z. (2011). Geochemistry of anorthositic differentiated sills in the Archean ( 2970 Ma) Fiskenæsset Complex, SW Greenland: Implications for parental magma compositions, geodynamic setting, and secular heat flow in arcs. Lithos, 123(1-4), 50-72.

Polat, A., Fryer, B.J., Samson, I.M., Weisener, C., Appel, P.W.U., Frei, R., \& Windley, B.F. (2012). Geochemistry of ultramafic rocks and hornblendite veins in the Fiskenæsset layered anorthosite complex, SW Greenland: Evidence for hydrous upper mantle in the Archean. Precambrian Research, 214-215, 124-153.

Polat, A., Longstaffe, F.J., \& Frei, R. (2018a). An overview of anorthosite-bearing layered intrusions in the Archaean craton of southern West Greenland and the Superior Province of Canada: implications for Archaean tectonics and the origin of megacrystic plagioclase. Geodinamica Acta, 30(1), 84-99.

Polat, A., Wang, L., \& Appel, P.W.U. (2015). A review of structural patterns and melting processes in the Archean craton of West Greenland: Evidence for crustal growth at convergent plate margins as opposed to non-uniformitarian models. Tectonophysics, 662, 67-94.

Praveen, M.N., Santosh, M., Yang, Q.Y., Zhang, Z.C., Huang, H., Singanenjam, S., \& Sajinkumar, K.S. (2014). Zircon U-Pb geochronology and Hf isotope of felsic volcanics from Attappadi, southern India: implications for Neoarchean convergent margin tectonics. Gondwana Research, 26(3-4), 907-924.

Raedeke, L.D., \& McCallum, I.S. (1984). Investigations in the Stillwater complex: Part II. Petrology and petrogenesis of the ultramafic series. Journal of Petrology, 25(2), 395-420.

Rahmani, F., Noghreyan, M., \& Mackizadeh, M.A. (2017). Mineral chemistry of the ultramafic and mafic cumulates in the eastern part of the Sabzevar ophiolite (NE Iran): evidence for formation of high pressure cumulates in thickened arc crust. Neues Jahrbuch für Geologie und Paläontologie-Abhandlungen, 286(3), 303-328.

Rajabzadeh, M.A., Dehkordi, T.N., \& Caran, Ş. (2013). Mineralogy, geochemistry and geotectonic significance of mantle peridotites with high-Cr chromitites in the Neyriz ophiolite from the outer Zagros ophiolite belts, Iran. Journal of African Earth Sciences, 78, 1-15.

Rao, Y.B., Kumar, A., Vrevsky, A.B., Srinivasan, R., \& Iyer, G.A. (2000). Sm-Nd ages of two meta-anorthosite complexes around Holenarsipur: Constraints on the antiquity of Archean supracrustal rocks of the Dharwar craton. Journal of Earth System Science, 109(1), 57-65.

Rao, P.S., Radhakrishna, M., Haripriya, K., Rao, B.S., \& Chandrasekharam, D. (2016). Magnetic anomalies over the Andaman Islands and their geological significance. Journal of Earth System Science, 125(2), 359-368.

Rao, C.D., Santosh, M., Sajeev, K., \& Windley, B.F. (2013). Chromite-silicate chemistry of the Neoarchean Sittampundi Complex, southern India: Implications for subduction-related arc magmatism. Precambrian Research, 227, 259-275. 
Reimink, J.R., Chacko, T., Stern, R.A., \& Heaman, L.M. (2016). The birth of a cratonic nucleus: lithogeochemical evolution of the 4.02-2.94 Ga Acasta Gneiss Complex. Precambrian Research, 281, 453-472.

Renna, M.R., Tribuzio, R., \& Ottolini, L. (2016). New perspectives on the origin of olivine-rich troctolites and associated harrisites from the Ligurian ophiolites (Italy). Journal of the Geological Society, 173, 916-932.

Ringuette, L. (1996). Thermobarometry of the garnet-bearing rocks of the Jijal Complex (western Himalayas, northern Pakistan). University of Leicester: Leicester, U.K., M.Sc. thesis, 146p.

Robertson, A., Parlak, O., Ustaömer, T., Taslı, K., İnan, N., Dumitrica, P., \& Karaoğlan, F. (2013). Subduction, ophiolite genesis and collision history of Tethys adjacent to the Eurasian continental margin: new evidence from the Eastern Pontides, Turkey. Geodinamica Acta, 26(34), 230-293.

Rolland, Y., Galoyan, G., Sosson, M., Melkonyan, R., \& Avagyan, A. (2010). The Armenian Ophiolite: insights for Jurassic back-arc formation, Lower Cretaceous hot spot magmatism and Upper Cretaceous obduction over the South Armenian Block. Geological Society, London, Special Publications, 340(1), 353-382.

Rollinson, H. (2008). The geochemistry of mantle chromitites from the northern part of the Oman ophiolite: inferred parental melt compositions. Contributions to Mineralogy and Petrology, 156, 273-288.

Rollinson, H., Appel, P.W. \& Frei, R. (2002). A metamorphosed, early Archaean chromitite from west Greenland: implications for the genesis of Archean anorthositic chromitites. Journal of Petrology, 43(11), 2143-2170.

Rollinson, H., Reid, C., \& Windley, B. (2010). Chromitites from the Fiskenæsset anorthositic complex, West Greenland: clues to late Archaean mantle processes. In T.M. Kusky, M.-G. Zhai, \& W. Xiao (Eds.). The Evolving Continents: Understanding Processes of Continental Growth. Geological Society, London, Special Publications, 338, 197-212.

Roman, A., \& Arndt, N. (2020). Differentiated Archean oceanic crust: its thermal structure, mechanical stability and a test of the sagduction hypothesis. Geochimica et Cosmochimica Acta, 278, 65-77.

Rowe, M.L., \& Kemp, A.I. (2020). Spinel, olivine, and pyroxene chemistry of the Eoarchaean Manfred Complex (Yilgarn Craton, Western Australia), with implications for the tectonic setting of Archaean layered mafic intrusions and the stabilisation of continental nuclei. Lithos, 356-357, 105340.

Ryan, B., \& Martineau, Y. (2012). Revised and coloured edition of 1992 map showing the Geology of the Saglek Fiord - Hebron Fiord area, Labrador (NTS 14L/2,3,6,7). Scale: 1:100000. Government of Newfoundland and Labrador, Department of Natural Resources, Geological Survey, Map 2012-15, Open File, 14L/0091. (Update of map originally released as Newfoundland Department of Mines and Energy, Geological Survey Branch, Map 92-18B and Geological Survey of Canada, Open File Report, 2466). 
Saccani, E. (2015). A new method of discriminating different types of post-Archean ophiolitic basalts and their tectonic significance using $\mathrm{Th}-\mathrm{Nb}$ and $\mathrm{Ce}-\mathrm{Dy}-\mathrm{Yb}$ systematics. Geoscience Frontiers, 6(4), 481-501.

Saccani, E., Delavari, M., Beccaluva, L. \& Amini, S. (2010). Petrological and geochemical constraints on the origin of the Nehbandan ophiolitic complex (eastern Iran): Implication for the evolution of the Sistan Ocean. Lithos, 117(1-4), 209-228.

Saccani, E., Padoa, E., \& Tassinari, R. (2000). Preliminary data on the Pineto gabbroic Massif and Nebbio basalts: progress toward the geochemical characterization of Alpine Corsica ophiolites. Ofioliti, 25(2), 75-85.

Saccani, E. \& Tassinari, R. (2015). The role of MORB and SSZ magma-types in the formation of Jurassic ultramafic cumulates in the Mirdita ophiolites (Albania) as deduced from chromian spinel and olivine chemistry. Ofioliti, 40(1), 37-56.

Saka, S., Uysal, I., Akmaz, R.M., Kaliwoda, M., \& Hochleitner, R. (2014). The effects of partial melting, melt-mantle interaction and fractionation on ophiolite generation: Constraints from the late Cretaceous Pozant1-Karsantı ophiolite, southern Turkey. Lithos, 202, 300-316.

Sakkarinejad, K. (2003). Structural and microstructural analysis of a palaeo-transform fault zone in the Neyriz ophiolite, Iran. In: Y. Dilek, \& P.T. Robinson (Eds.). Ophiolites in Earth History. Geological Society, London, Special Publications, 218, 129-145.

Sałacińska, A., Kusiak, M.A., Whitehouse, M.J., Dunkley, D.J., Wilde, S.A., Kielman, R., \& Król, P. (2019). Gneiss-forming events in the Saglek Block, Labrador; a reappraisal of the Uivak gneiss. International Journal of Earth Sciences, 108, 753-778.

Salavati, M., Kananian, A., \& Noghreyan, M. (2013). Geochemical characteristics of mafic and ultramafic plutonic rocks in southern Caspian Sea Ophiolite (Eastern Guilan). Arabian Journal of Geosciences, 6(12), 4851-4858.

Samuel, V.O., Santosh, M., Liu, S., Wang, W., \& Sajeev, K. (2014). Neoarchean continental growth through arc magmatism in the Nilgiri Block, southern India. Precambrian Research, 245, 146-173.

Sandeman, H.A., Brown, J., Studnicki-Gizbert, C., MacHattie, T., Hyde, D., Johnstone, S., Greiner, E., \& Plaza, D. (2001). Bedrock mapping in the Committee Bay belt, Laughland Lake area, central mainland, Nunavut. Natural Resources Canada, Geological Survey of Canada, 28p.

Santosh, M., \& Li, S.S. (2018). Anorthosites from an Archean continental arc in the Dharwar Craton, southern India: implications for terrane assembly and cratonization. Precambrian Research, 308, 126-147.

Santosh, M., Shaji, E., Tsunogae, T., Mohan, M.R., Satyanarayanan, M., \& Horie, K. (2013). Suprasubduction zone ophiolite from Agali hill: petrology, zircon SHRIMP U-Pb geochronology, geochemistry and implications for Neoarchean plate tectonics in southern India. Precambrian Research, 231, 301-324. 
Santosh, M., Teng, X.M., He, X.F., Tang, L., \& Yang, Q.Y. (2016). Discovery of Neoarchean suprasubduction zone ophiolite suite from Yishui Complex in the North China Craton. Gondwana Research, 38, 1-27.

Sappin, A.A., Houlé, M.G., Lesher, C.M., McNicoll, V., Vaillancourt, C., \& Kamber, B.S. (2016). Age constraints and geochemical evolution of the Neoarchean mafic-ultramafic Wabassi Intrusive Complex in the Miminiska-Fort Hope greenstone belt, Superior Province, Canada. Precambrian Research, 286, 101-125.

Sappin, A.-A., Houlé, M.G., Lesher, C.M., Metsaranta, R.T., \& McNicoll, V.J. (2015). Regional characterization of mafic-ultramafic intrusions in the Oxford-Stull and Uchi domains, Superior Province, Ontario, In D.E. Ames, \& M.G. Houlé (Eds.). Targeted Geoscience Initiative 4: Canadian Nickel-Copper-Platinum Group Elements-Chromium Ore Systems - Fertility, Pathfinders, New and Revised Models. Geological Survey of Canada, Open File, 7856, 75-85.

Saunders, A.D., Tarney, J., \&Weaver, S.D. (1980). Transverse geochemical variations across the Antarctic Peninsula: Implications for the genesis of calc-alkaline magmas. Earth and Planetary Science Letters, 46, 344-360.

Savov, I., Ryan, J., Haydoutov, I., \& Schijf, J. (2001). Late Precambrian Balkan-Carpathian ophiolite-A slice of the Pan-African ocean crust?: Geochemical and tectonic insights from the Tcherni Vrah and Deli Jovan massifs, Bulgaria and Serbia. Journal of Volcanology and Geothermal Research, 110(3-4), 299-318.

Scherreiks, R. (2000). Platform margin and oceanic sedimentation in a divergent and convergent plate setting (Jurassic, Pelagonian Zone, NE Evvoia, Greece). International Journal of Earth Sciences, 89(1), 90-107.

Scherreiks, R., Meléndez, G., BouDagher-Fadel, M., Fermeli, G., \& Bosence, D. (2014). Stratigraphy and tectonics of a time-transgressive ophiolite obduction onto the eastern margin of the Pelagonian platform from Late Bathonian until Valanginian time, exemplified in northern Evvoia, Greece. International Journal of Earth Sciences, 103(8), 2191-2216.

Schmitz, M.D., Bowring, S.A., de Wit, M.J., \& Gartz, V. (2004). Subduction and terrane collision stabilize the western Kaapvaal craton tectosphere 2.9 billion years ago. Earth and Planetary Science Letters, 222(2), 363-376.

Schultz, M.E., Chacko, T., Heaman, L.M., Sandeman, H.A., Simonetti, A., \& Creaser, R.A. (2007). Queen Maud block: A newly recognized Paleoproterozoic (2.4-2.5 Ga) terrane in northwest Laurentia. Geology, 35(8), 707-710.

Šegvic, B. (2010). Petrologic and geochemical characteristics of the Krivaja-Konjuh ophiolite complex (NE Bosnia and Herzegovina) - petrogenesis and regional geodynamic implications. University of Heidelberg; Heidelberg, Germany, Ph.D. thesis, 313p.

Šegvić, B., Kukoč, D., Dragičević, I., Vranjković, A., Brčić, V., Goričan, Š., Babajić, E., \& Hrvatović, H. (2014). New record of Middle Jurassic radiolarians and evidence of Neotethyan dynamics documented in a mélange from the Central Dinaridic Ophiolite belt (CDOB, NE Bosnia and Herzegovina). Ofioliti, 39(1), 31-41. 
Şengör, A. M. C. (1979). Mid-Mesozoic closure of Permo-Triassic Tethys and its implications. Nature, 279, 590-593.

Şengör, A. M. C. (1990). Plate tectonics and orogenic research after 25 years: A Tethyan perspective. Earth Science Reviews, 27, 1-201.

Şengör, A.M.C., Lom, N., Sunal, G., Zabc1, C., \& Sancar, T. (2019). The phanerozoic palaeotectonics of Turkey. Part I: an inventory. Mediterranean Geoscience Reviews, 1, 91-161. Şengör, A.M.C., \& Natal'in, B.A. (2004). Phanerozoic analogues of Archaean oceanic basement fragments: Altaid ophiolites and ophirags. In T.M. Kusky (Ed.). Precambrian Ophiolites and Related Rocks. Elsevier B.V: Amsterdam, Developments in Precambrian Geology, 13, 675726.

Şengör, A.M.C., Natal'in, B.A., Sunal, G. and van der Voo, R. (2018). The tectonics of the Altaids: crustal growth during the construction of the continental lithosphere of Central Asia between 750 and $130 \mathrm{Ma}$ ago. Annual Review of Earth and Planetary Sciences, 46, 439-494.

Şengör, A. M. C., \& Yılmaz, Y. (1981). Tethyan evolution of Turkey: a plate tectonic approach. Tectonophysics, 75, 181-241.

Sharkov, E.V., Krassivskaya, I.S., \& Chistyakov, A.V. (2004). Dispersed mafic-ultramafic intrusive magmatism in Early Paleoproterozoic mobile zones of the Baltic Shield: an example of the Belomorian drusite (coronite) complex. Petrology, 12(6), 561-582.

Sharkov, E.V., Smol'kin, V.F., Belyatskii, V.B., Chistyakov, A.V., \& Fedotov, Z.A. (2006). Age of the Moncha Tundra fault, Kola Peninsula: Evidence from the Sm-Nd and Rb-Sr isotopic systematics of metamorphic assemblages. Geochemistry International, 44(4), 317-326.

Sheraton, J.W., Offe, L.A., Tingey, R.J., \& Ellis, D.J. (1980). Enderby land, Antarctica - an unusual Precambrian high-grade metamorphic terrain. Journal of the Geological Society of Australia, 27 (1-2), 1-18.

Simmons, E.C., Hanson, G.N., \& Lumbers, S.B. (1980). Geochemistry of the Shawmere anorthosite complex, Kapuskasing structural zone, Ontario. Precambrian Research, 11(1), 4371.

Sisson, T.W., \& Grove, T.L. (1993). Temperatures and $\mathrm{H}_{2} \mathrm{O}$ contents of low $\mathrm{MgO}$ high-alumina basalts. Contributions to Mineralogy and Petrology, 113, 167-184.

Sleep, N. H., \& Windley, B. F. (1982). Archean Plate Tectonics: Constraints and Inferences. The Journal of Geology, 90(4). 363-379.

Slovenec, D., \& Šegvić, B. (2019). Boninite volcanic rocks from the mélange of NW DinaricVardar ophiolite zone (Mt. Medvednica, Croatia)-record of Middle to Late Jurassic arc-forearc system in the Tethyan subduction factory. Mineralogy and Petrology, 113(1), 17-37.

Sotiriou, P. (2012). Geochemical and mineralogical differences in rocks either side of the Petrological Moho, Troodos Ophiolite, Cyprus. Kingston University: Kingston, London, United Kingdom, B.Sc. thesis.

Sotiriou, P., Polat, A., \& Frei, R. (2019b). Petrogenesis and geodynamic setting of the Neoarchaean Haines Gabbroic Complex and Shebandowan greenstone belt, Southwestern Superior Province, Ontario, Canada. Lithos, 324-325, 1-19. 
Sotiriou, P., Polat, A., Frei, R., Yang, X.M., \& van Vessem, J. (2019a). A back-arc origin for the Neoarchean megacrystic anorthosite-bearing Bird River Sill and the associated greenstone belt, Bird River subprovince, Western Superior Province, Manitoba, Canada. International Journal of Earth Sciences, 108(7), 2177-2207.

Sotiriou, P., Polat, A., Frei, R., Yang, X.M., \& van Vessem, J. (2020). Evidence for Neoarchean hydrous arc magmatism, the anorthosite-bearing Mayville Intrusion, western Superior Province, Canada. Lithos, 362-363, 105482, https://doi.org/10.1016/j.lithos.2020.105482.

Souders, A.K., Sylvester, P.J., \& Myers, J.S. (2013). Mantle and crustal sources of Archean anorthosite: a combined in situ isotopic study of $\mathrm{Pb}-\mathrm{Pb}$ in plagioclase and $\mathrm{Lu}-\mathrm{Hf}$ in zircon. Contributions to Mineralogy and Petrology, 165(1), 1-24.

Spath, C.S. III, Lesher, C.M., \& Houlé, M.G. (2015). Hybridized ultramafic rocks in the Black Label hybrid zone of the Black Thor intrusive complex, McFaulds Lake greenstone belt, Ontario, In: D.E. Ames, \& M.G. Houlé (Eds.). Targeted Geoscience Initiative 4: Canadian Nickel-Copper-Platinum Group Elements-Chromium Ore Systems - Fertility, Pathfinders, New and Revised Models. Geological Survey of Canada, Open File, 7856, 103-114.

Stern, R.J., Fouch, M.J., \& Klemperer, S.L. (2003). An overview of the Izu-Bonin-Mariana subduction factory. In J. Eiler (Ed.). Inside The Subduction Factory. American Geophysical Union, Geophysical Monograph, 138, 175-222.

Stern, R.J., \& Bloomer, S.H. (1992). Subduction zone infancy: Examples from the Eocene IzuBonin-Mariana and Jurassic California arcs. Geological Society of America Bulletin, 104, 1621-1636.

Sultan, M., Tucker, R.D., El Alfy, Z., Attia, R., \& Ragab, A.G. (1994). U-Pb (zircon) ages for the gneissic terrane west of the Nile, southern Egypt. Geologische Rundschau, 83(3), 514-522.

Sunder-Raju, P.V., Hanski, E. \& Lahaye, Y. (2015). LA-MC-ICP-MS dating of zircon from chromitite of the Archean Bangur Gabbro Complex, Orissa, India: ambiguities and constraints. Geologica Acta, 13(4), 325-334.

Takagi, D., Sato, H., \& Nakagawa, M. (2005). Experimental study of a low-alkali tholeiite at 1-5 kbar: optimal condition for the crystallization of high-An plagioclase in hydrous arc tholeiite. Contributions to Mineralogy and Petrology, 149, 527-540.

Takahashi, Y., Mikoshiba, M.U., Takahashi, Y., Kausar, A.B., Khan, T., \& Kubo, K. (2007). Geochemical modelling of the Chilas Complex in the Kohistan Terrane, northern Pakistan. Journal of Asian Earth Sciences, 29(2-3), 336-349.

Tang, Y., Zhai, Q.G., Hu, P.Y., Wang, J., Xiao, X.C., Wang, H.T., Tang, S.H., \& Lei, M. (2018). Rodingite from the Beila ophiolite in the Bangong-Nujiang suture zone, northern Tibet: New insights into the formation of ophiolite-related rodingite. Lithos, 316, 33-47.

Tankard, A.J., Jackson, M.P.A., Eriksson, E.A., Hobday, D.K., Hunter, D.R., \& Minter, W.E.L. (1982). Crustal Evolution of Southern Africa. Springer-Verlag: Berlin, 523 p.

Taylor, R.N., \& Nesbitt, R.W. (1988). Light rare-earth enrichment of supra subduction-zone mantle: Evidence from the Troodos ophiolite, Cyprus. Geology, 16(5), 448-451. 
Tenczer, V., Hauzenberger, C.A., Fritz, H., Whitehouse, M.J., Mogessie, A., Wallbrecher, E., Muhongo, S., \& Hoinkes, G. (2006). Anorthosites in the Eastern Granulites of Tanzania-new SIMS zircon U-Pb age data, petrography and geochemistry. Precambrian Research, 148(1-2), 85-114.

Thayer, T.P. (1980). Syncrystallization and subsolidus deformation in ophiolitic peridotite and gabbro. American Journal of Science, 280, 269-283.

Turner, Wilde, S., Wörner, G., Schaefer, B., \& Lai, Y.J. (2020). An andesitic source for Jack Hills zircon supports onset of plate tectonics in the Hadean. Nature Communications (2020), 11:1241 | https://doi.org/10.1038/s41467-020-14857-1.

van de Löcht, J., Hoffmann, J.E., Rosing, M.T., Sprung, P., \& Münker, C. (2020). Preservation of Eoarchean mantle processes in $3.8 \mathrm{Ga}$ peridotite enclaves in the Itsaq Gneiss Complex, southern West Greenland. Geochimica et Cosmochimica Acta, 280, 1-25.

Van Kranendonk, M.J., \& Helmstaedt, H. (1990). Late Archean geologic history of the Nain Province, North River-Nutak map area, Labrador, and its tectonic significance. Geoscience Canada, 17(4), 231-237.

Van Kranendonk, M.J., Hickman, A.H., Smithies, R.H., Nelson, D.R., \& Pike, G. (2002). Geology and tectonic evolution of the Archean North Pilbara terrain, Pilbara Craton, Western Australia. Economic Geology, 97(4), 695-732.

Vogler, W.S. (1987). Fabric development in a fragment of Tethyan oceanic lithosphere from the Piemonte ophiolite nappe of the Western Alps, Valtournanche, Italy. Journal of Structural Geology, 9(8), 935-953.

Vrevskii, A.B. (2016). Age and sources of the anorthosites of the Neoarchean KolmozeroVoron'ya greenstone belt (Fennoscandian Shield). Petrology, 24(6), 527-542.

Wang, B., Wang, L., Chen, J., Yin, F., Wang, D., Zhang, W., Chen, L., \& Liu, H. (2014). Triassic three-stage collision in the Paleo-Tethys: constraints from magmatism in the Jiangda-DeqenWeixi continental margin arc, SW China. Gondwana Research, 26(2), 475-491.

Wang, B.D., Wang, L.Q., Chung, S.L., Chen, J.L., Yin, F.G., Liu, H., Li, X.B., \& Chen, L.K. (2016). Evolution of the Bangong-Nujiang Tethyan ocean: insights from the geochronology and geochemistry of mafic rocks within ophiolites. Lithos, 245, 18-33.

Watson, J. (1969). The Precambrian gneiss complex of Ness, Lewis, in relation to the effects of Laxfordian regeneration. Scottish Journal of Geology, 5(3), 269-285.

Wiebe, R.A. (1992). Proterozoic anorthosite complexes. In: Condie, K.C. (ed.). Proterozoic Crustal Evolution. Elsevier: Amsterdam, The Netherlands, Developments in Precambrian Geology, 10, 215-261.

Wiener, R.W. (1981). Tectonic setting, rock chemistry, and metamorphism of an Archean gabbroanorthosite complex, Tessiuyakh Bay, Labrador. Canadian Journal of Earth Sciences, 18(9), 1409-1421.

Williams, H.R. (1988). The Archean Kasila Group of western Sierra Leone: geology and relations with adjacent granite-greenstone terrane. Precambrian Research, 38(3), 201-213. 
Williams, H.R. (1989). Geology and mineral chemistry of the Bantoro Leucogabbro, Kasila group, western Sierra Leone. Journal of African Earth Sciences (and the Middle East), 9(2), 259-271.

Windley, B.F., \& Garde, A.A. (2009). Arc-generated blocks with crustal sections in the North Atlantic craton of West Greenland: crustal growth in the Archean with modern analogues. Earth-Science Reviews, 93(1-2), 1-30.

Windley, B.F., \& Smith, J.V. (1974). The Fiskenæsset Complex, West Greenland, part 2. General Mineral Chemistry from Qeqertarssuatsiaq. Grønlands Geologiske Unders $\phi$ gelse Bulletin, 108, $54 \mathrm{p}$.

Woelki, D., Regelous, M., Haase, K.M., Romer, R.H.W., \& Beier, C. (2018). Petrogenesis of boninitic lavas from the Troodos Ophiolite, and comparison with Izu-Bonin-Mariana fore-arc crust. Earth and Planetary Science Letters, 498, 203-214.

Wu, T., Polat, A., Frei, R., Fryer, B.J., Yang, K.-G., \& Kusky, T. (2016). Geochemistry, Nd, Pb and $\mathrm{Sr}$ isotope systematics, and $\mathrm{U}-\mathrm{Pb}$ zircon ages of the Neoarchean Bad Vermilion Lake greenstone belt and spatially associated granitic rocks, western Superior Province, Canada. Precambrian Research, 282, 21-51.

Wyman, D.A. (2019). 2.6 Ga subduction-related magmatism in the Youanmi Terrane and a revised geodynamic model for the Yilgarn Craton. Precambrian Research, 327, 14-33.

Yamasaki, T., Maeda, J., \& Mizuta, T. (2006). Geochemical evidence in clinopyroxenes from gabbroic sequence for two distinct magmatisms in the Oman ophiolite. Earth and Planetary Science Letters, 251, 52-65.

Yang, X.M. (2013). Bedrock geology of the Cat Lake-Euclid Lake area, Bird River greenstone belt, southeastern Manitoba (parts of NTS 52L11, 12). Manitoba Mineral Resources, Manitoba Geological Survey, Preliminary Map PMAP2013-7, scale 1:10000.

Yang, X.M., \& Gilbert, H.P. (2014). Mineral chemistry of chromite in the Mayville intrusion: evidence for petrogenesis and linkage to the Bird River sill in the Neoarchean Bird River greenstone belt, southeastern Manitoba (NTS 52L5, 6, 12). In Report of Activities 2014. Manitoba Mineral Resources, Manitoba Geological Survey, 32-48.

Yang, X.M., Gilbert, H.P., Corkery, M.T., \& Houlé, M.G. (2011). The Mayville mafic-ultramafic intrusion in the Neoarchean Bird River greenstone belt, southeastern Manitoba (part of NTS 52L12): preliminary geochemical investigation and implication for PGE-Ni-Cu-(Cr) mineralization. In Report of Activities 2011. Manitoba Innovation, Energy and Mines, Manitoba Geological Survey, 127-142.

Yang, X.M., Gilbert, H.P., \& Houlé, M.G. (2013). Cat Lake-Euclid Lake area in the Neoarchean Bird River greenstone belt, southeastern Manitoba (parts of NTS 52L11, 12): preliminary results of bedrock geological mapping and their implications for geodynamic evolution and metallogeny. In Report of Activities 2013. Manitoba Mineral Resources, Manitoba Geological Survey, 70-84.

Yellappa, T., Santosh, M., Chetty, T.R.K., Kwon, S., Park, C., Nagesh, P., Mohanty, D.P., \& Venkatasivappa, V. (2012). A Neoarchean dismembered ophiolite complex from southern 
India: geochemical and geochronological constraints on its suprasubduction origin. Gondwana Research, 21(1), 246-265.

Yellappa, T., Venkatasivappa, V., Koizumi, T., Chetty, T.R.K., Santosh, M., \& Tsunogae, T. (2014). The mafic-ultramafic complex of Aniyapuram, Cauvery Suture Zone, southern India: Petrological and geochemical constraints for Neoarchean suprasubduction zone tectonics. Journal of Asian Earth Sciences, 95, 81-98.

Y1lmaz, Y. (2019). Southeast Anatolian Orogenic Belt Revisited (Geology and Evolution). Canadian Journal of Earth Sciences, 56(11), 1163-1180.

Yılmaz, Y., Gözübol, A.M., \& Tüysüz, O. (1982). Geology of an area in and around the Northern Anatolian transform fault zone between Bolu and Akyazi. In A.M. Isikara, \& A. Vogel (Eds.). Multidisciplinary Approach to Earthquake Prediction. Vieweg+ Teubner Verlag: Wiesbaden, Germany, 45-65.

Zakariadze, G., Karamata, S., Korikovsky, S., Ariskin, A., Adamia, S., Chkhotua, T., Sergeev, S, \& Solov'eva, N. (2012). The Early-Middle Palaeozoic Oceanic Events Along the Southern European Margin: The Deli Jovan Ophiolite Massif (NE Serbia) and Palaeo-oceanic Zones of the Great Caucasus. Turkish Journal of Earth Sciences, 21(5), 635-668.

Zarrinkoub, M.H., Pang, K.N., Chung, S.L., Khatib, M.M., Mohammadi, S.S., Chiu, H.Y., \& Lee, H.Y. (2012). Zircon U-Pb age and geochemical constraints on the origin of the Birjand ophiolite, Sistan suture zone, eastern Iran. Lithos, 154, 392-405.

Zeh, A., Gerdes, A., \& Millonig, L. (2011). Hafnium isotope record of the Ancient Gneiss Complex, Swaziland, southern Africa: evidence for Archaean crust-mantle formation and crust reworking between 3.66 and 2.73 Ga. Journal of the Geological Society, 168(4), 953-964.

Zeh, A., Jaguin, J., Poujol, M., Boulvais, P., Block, S., \& Paquette, J.L. (2013). Juvenile crust formation in the northeastern Kaapvaal Craton at $2.97 \mathrm{Ga}$-Implications for Archean terrane accretion, and the source of the Pietersburg gold. Precambrian Research, 233, 20-43.

Zeng, X.W., Wang, M., Fan, J.J., Li, C., Xie, C.M., Liu, Y.M., \& Zhang, T.Y. (2018). Geochemistry and geochronology of gabbros from the Asa Ophiolite, Tibet: Implications for the early Cretaceous evolution of the Meso-Tethys Ocean. Lithos, 320, 192-206.

Zhai, Q.G., Jahn, B.M., Wang, J., Su, L., Mo, X.X., Wang, K.L., Tang, S.H., \& Lee, H.Y. (2013). The Carboniferous ophiolite in the middle of the Qiangtang terrane, Northern Tibet: SHRIMP $\mathrm{U}-\mathrm{Pb}$ dating, geochemical and $\mathrm{Sr}-\mathrm{Nd}-\mathrm{Hf}$ isotopic characteristics. Lithos, 168, 186-199.

Zhang, W., Pease, V., Whitehouse, M.J., El-Sankary, M.M., \& Shalaby, M.H. (2018). PreNeoproterozoic basement evolution of southwestern Egypt. International Geology Review., 61(15), 1909-1926.

Zhang, Q., Wang, Y., Zhou, G.Q., Qian, Q., \& Robinson, P.T. (2003). Ophiolites in China: their distribution, ages and tectonic settings. Geological Society, London, Special Publications, 218(1), 541-566.

Zhou, M.F., \& Bai, W.J. (1992). Chromite deposits in China and their origin. Mineralium Deposita, 27(3), 192-199. 
Zhou, S., Polat, A., Longstaffe, F.J., Yang, K., Fryer, B.J., \& Weisener, C. (2016). Formation of the Neoarchean Bad Vermilion Lake Anorthosite Complex and spatially associated granitic rocksat a convergent plate margin, Superior Province, Western Ontario, Canada. Gondwana Research, 33, 134-159.

Zhu, Y., \& Peng, E. (1996). The Animaqen ophiolite in Qinghai Province. Journal of Central South University of Technology, 3(1), 67-69.

Zhu, W.G., Zhong, H., Yang, Y.J., \& Ren, T. (2016). The origin of the Dapingzhang volcanogenic $\mathrm{Cu}-\mathrm{Pb}-\mathrm{Zn}$ ore deposit, Yunnan province, SW China: Constraints from host rock geochemistry and ore $\mathrm{Os}-\mathrm{Pb}-\mathrm{S}-\mathrm{C}-\mathrm{O}-\mathrm{H}$ isotopes. Ore Geology Reviews, 75, 327-344.

Zi, J.W., Cawood, P.A., Fan, W.M., Wang, Y.J., \& Tohver, E. (2012). Contrasting rift and subduction-related plagiogranites in the Jinshajiang ophiolitic mélange, southwest China, and implications for the Paleo-Tethys. Tectonics, 31(2). doi:10.1029/2011TC002937.

Zirner, A.L.K. (2017). Fluid drive processes in the crust - the formation of anorthositic dykes in the Troodos ophiolite (Cyprus). Universität Bonn, Ph.D. thesis, 241p.

Zirner, A., Balhaus, C., Münker, C., \& Marien, C. (2013). Anorthosite dikes from Cyprus; phase relations in the system $\mathrm{CaAl}_{2} \mathrm{Si}_{2} \mathrm{O}_{8}-\mathrm{CaMgSi}_{2} \mathrm{O}_{6}-\mathrm{Mg}_{2} \mathrm{SiO}_{4}$ at 5 wt. \% H2O. Mineralogical Magazine, 77, 2621, Abstract.

\section{Figure captions}

Figure 1. Map showing the distribution of Tethyan anorthosite-bearing ophiolites and the location of the Tethysides (modified after Şengör et al., 2018). The locations of selected Tethyan anorthosite-bearing ophiolites are based on information from the references cited in Table S1.

Figure 2. Stratigraphic columns for the Neyriz and Chilas Complex Tethyan anorthosite-bearing ophiolites (modified after Takahashi et al. (2007) and Moghadam et al. (2014). The stratigraphic column for the Chilas Complex ophiolite encompasses the ultramafic-mafic-anorthosite (UMA) association east of Chilas Town in Pakistan.

Figure 3. World map showing the distribution and age of Archean anorthosite occurrences (modified after Zhou et al., 2016) based on information from the references cited in Table S2. The numbers correspond to the occurrences listed in Table S2.

Figure 4. Stratigraphic columns for the Fiskenæsset Complex, Bird River Sill, Mayville Intrusion and Doré Lake Complex Archean megacrystic anorthosite-bearing layered intrusions (modified after Polat et al. (2011), Yang et al. (2011), Yang and Gilbert (2014) and Mathieu (2019)).

Figure 5. Field photographs of Archean calcic megacrystic anorthosite-bearing layered intrusions. (a) Megacrystic leucogabbros from the Fiskenæsset Complex, Greenland. (b) Megacrystic anorthosites interlayered with chromitites from the Fiskenæsset Complex, Greenland. (c) Magmatic layering in the Fiskenæsset Complex, Greenland. (d) Megacrystic anorthosite from the 
Mayville Intrusion, Canada. Primary, cumulate textures and igneous minerals are well preserved. plag: plagioclase, i-amp: igneous amphibole.

Figure 6. Simplified geological map of the Fiskenæsset region, southwestern Greenland, showing the distribution of TTG gneisses, Fiskenæsset Complex, amphibolites (basalts), and granites (modified after Myers, 1976, 1985).

Figure 7. (a-b) Emplacement of a tonalite sheet along a thrust fault zone between two layers of anorthosite-leucogabbro at Sinarssuk in the Fiskenæsset anorthosite-bearing layered intrusion (modified from Polat et al., 2015). (c) A simplified cross-section of the Fiskenæsset region from Grædefjord, through Majorqap qâva, to Bjørnesund; $F_{1}$ and $F_{2}$ represent the folds formed during first and second folding episodes (modified from Myers, 1985).

Figure 8. Pie diagrams showing the temporal distribution of (a) Tethyan anorthosite-bearing ophiolites and (b) Archean anorthosite-bearing layered intrusions.

Figure 9. Pie diagrams showing the proportion of the different geodynamic settings of (a) Tethyan anorthosite-bearing ophiolites and (b) Archean anorthosite-bearing layered intrusions.

Figure 10. Pie diagrams showing the proportion of subduction-related versus subductionunrelated (a) Tethyan anorthosite-bearing ophiolites and (b) Archean anorthosite-bearing layered intrusions.

Figure 11. Pie diagrams showing the proportion of boninitic versus non-boninitic (a) Tethyan anorthosite-bearing ophiolites and (b) Archean anorthosites-bearing layered intrusions.

Figure 12. Pie diagrams showing the respective proportions of the parental magmas to (a) Tethyan anorthosite-bearing ophiolites and their proportions and (b) Archean anorthosites-bearing layered intrusions.

Figure 13. (a) Temporal variation in the anorthite (An) content of plagioclase in anorthosites from Tethyan anorthosite-bearing ophiolites. The inset is a frequency graph showing the distribution of the plagioclase An content of Tethyan anorthosite-bearing ophiolites. (b) shows the corresponding tectonic setting of the Tethyan anorthosite-bearing ophiolites containing plagioclase that have known An contents. These anorthite contents were derived from the cores and rims of plagioclase crystals and are igneous and metamorphic in origin.

Figure 14. (a) Temporal variation in the anorthite (An) content of plagioclase in Archean anorthosite-bearing layered intrusions. The inset is a frequency graph showing the distribution of the plagioclase An content of Archean anorthosite-bearing layered intrusions. (b) shows the 
1917 corresponding tectonic settings of Archean anorthosite-bearing layered intrusions that have 1918 plagioclase with known An contents. These anorthite contents were derived from the cores and 1919 rims of plagioclase crystals and are igneous and metamorphic in origin.

1920

Figure 15. Plagioclase An content versus pyroxene Mg\# plot for Tethyan anorthosite-bearing ophiolites and Archean anorthosite-bearing layered intrusions.

Figure 16. A schematic diagram showing the geodynamic settings of Tethyan anorthositebearing ophiolites and Archean anorthosite-bearing layered intrusions. MOR: Mid-ocean ridge.

\section{Table captions}

Table 1. A list of the most well-studied major Tethyan anorthosite-bearing ophiolites (based on information from Taylor and Nesbitt, 1988; Sakkarinejad, 2003; Bortolotti et al., 2004; Jagoutz et al., 2006; Dilek and Thy, 2009; Goodenough et al., 2010; Piccardo and Guarnieri, 2011; Saccani and Tassinari, 2015; Alparslan and Dilek, 2018; Kapsiotis et al., 2019).

Table 2. A list of the most well-studied major Archean anorthosite-bearing layered intrusions (based on information from Garson and Livingstone, 1973; Myers, 1988; Barton Jr., 1996; Boudreau et al., 1997; Paixão and Oliveira, 1998; Polat et al., 2011, 2018a, b; Mohan et al., 2013; Zhou et al., 2016; Sotiriou et al., 2019a).

Table 3. Evidence presented in the literature for the different geodynamic settings proposed for Tethyan (T) and Archean (A) anorthosites (based on Tables S1 and S2; Pearce, 2008, 2014; Furnes et al., 2014, 2015; Polat et al., 2018a).

\section{Supporting Information}

Figure S1. Map showing the distribution and ages of Tethyan anorthosite-bearing ophiolites in Italy, France, Corsica, and the Balkans (modified after Dilek and Furnes, 2009).

Table S1. Tethyan anorthosite-bearing ophiolite occurrences.

Figure S2. Map showing the distribution and ages of Tethyan anorthosite-bearing ophiolites in the Balkans, Greece, Cyprus, Turkey, Armenia, and the Middle East (modified after Dilek and Furnes, 2009).

Table S2. Archean anorthosite-bearing layered intrusion occurrences.

Figure S3. Map showing the distribution and ages of Tethyan anorthosite-bearing ophiolites in Iran and Oman (modified after Dilek and Furnes, 2009). 
1957 Figure S4. Map showing the distribution and ages of Tethyan anorthosite-bearing ophiolites in the Himalayas (modified after Dilek and Furnes, 2009). 


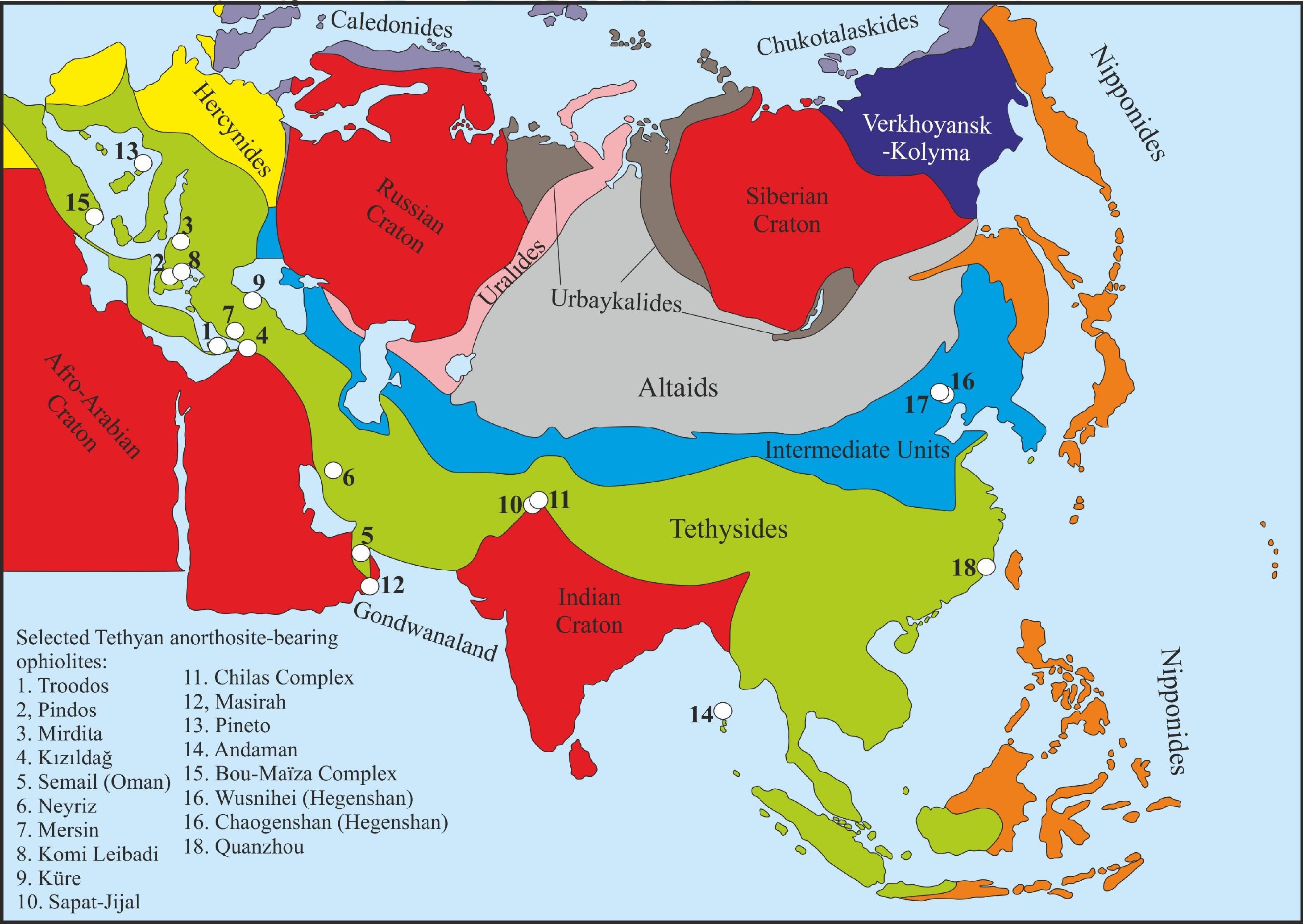




\section{Neyriz}

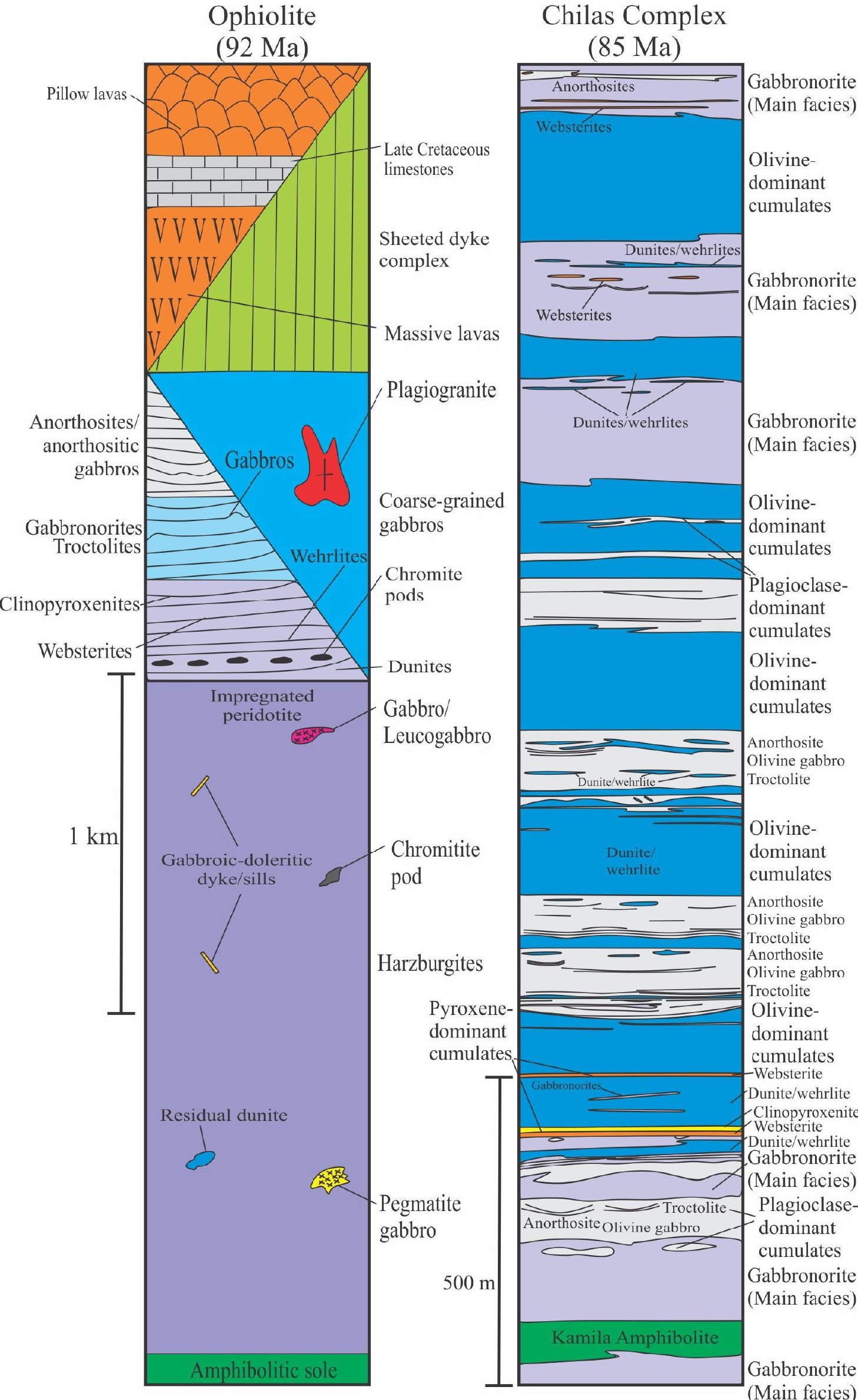




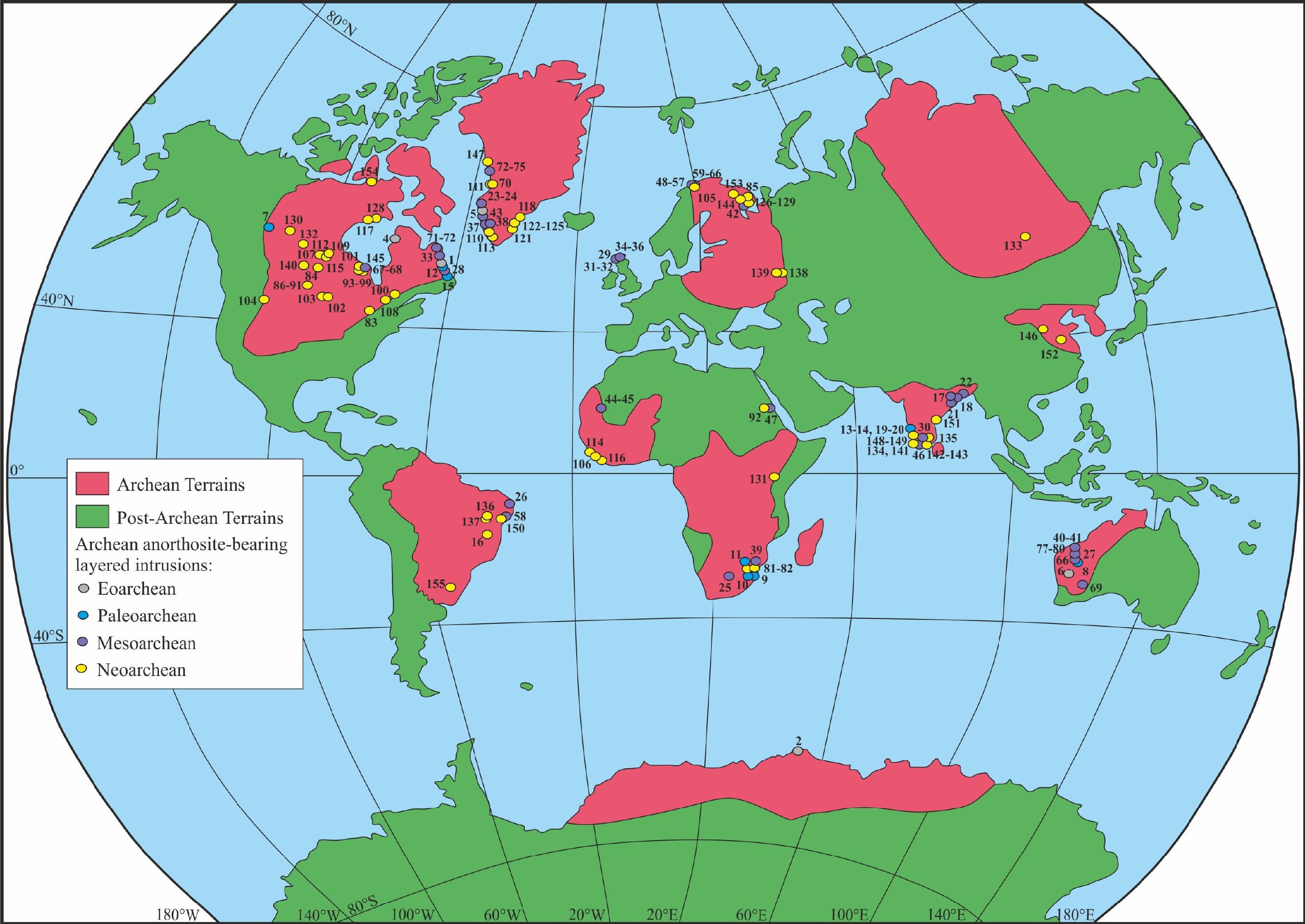


Fiskenæsset

Complex

(2973 Ma)

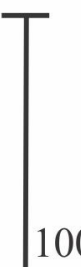

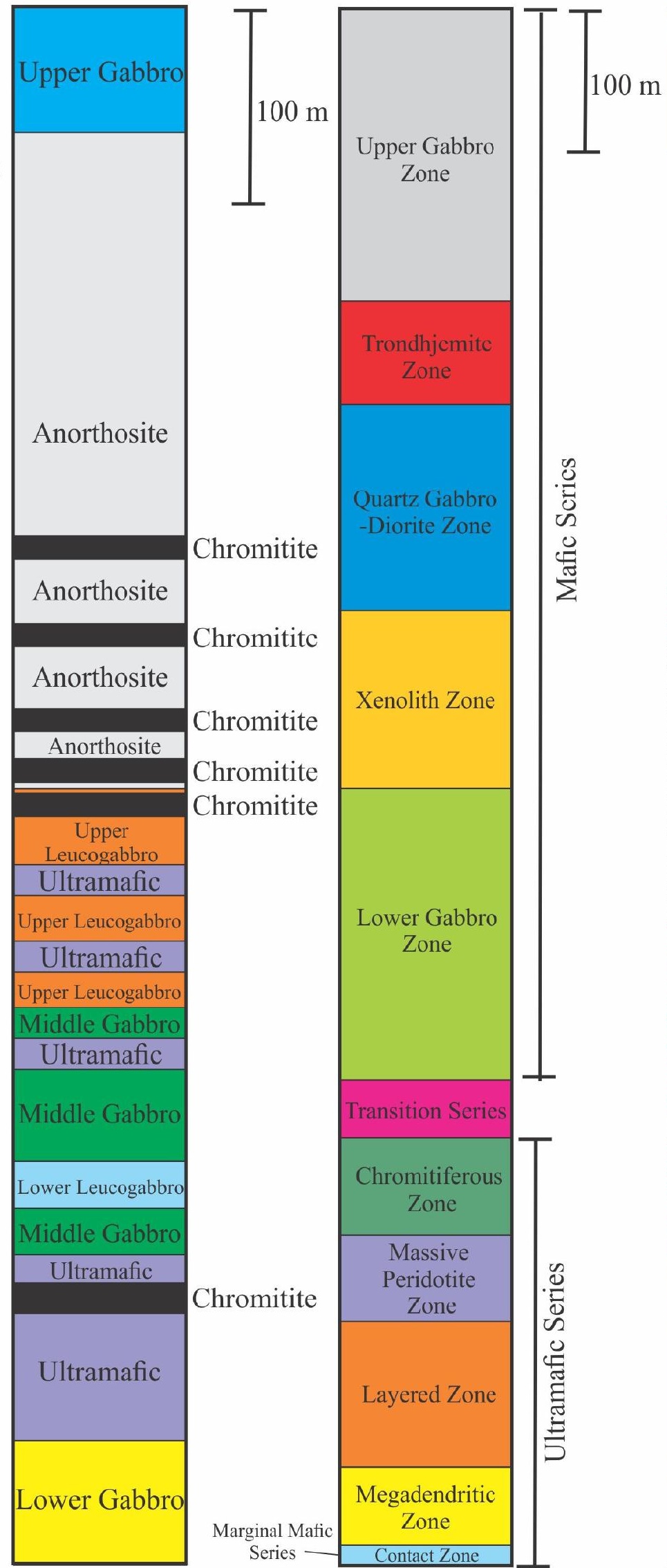

Mayville

Intrusion

(2743 Ma)

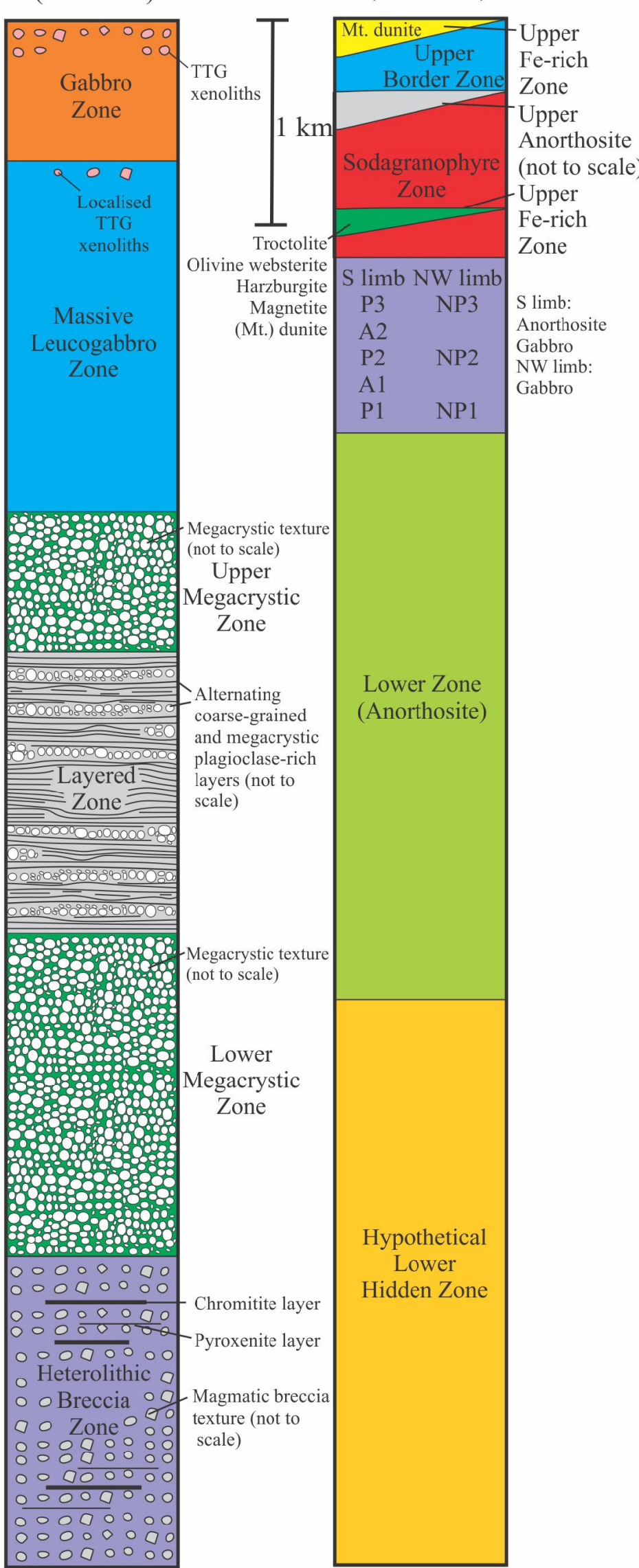

Doré Lake

Complex

(2728 Ma)

egacrystic

ayers (not to

cale)

Megacrystic texture (not to scale)

Lower

Megacrystic

Zone

pothetica

Lower

- Chromitite layer

Pyroxenite layer

Magmatic brecci

texture (not to

$\checkmark$ o Zone 0 o o texture (ncale)

$\begin{array}{lllllllllll}0 & 0 & 0 & 0 & 0 & 0 & 0 & 0 \\ 0 & 0 & 0 & 0 & 0 & 0 & 0 & 0\end{array}$

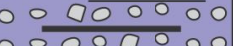

00000000

00000000 

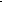
(a)

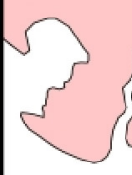

th 0

Graedefjord
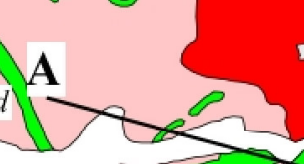
$y=$

$70^{300} \mathrm{~W}$

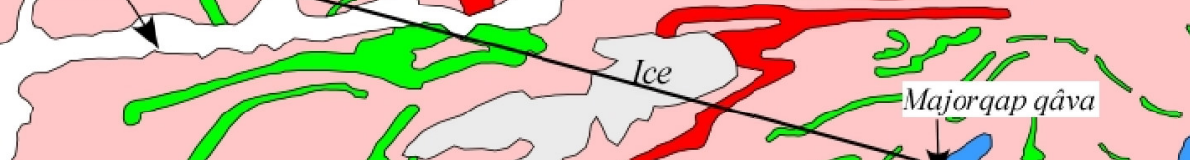

$\uparrow$
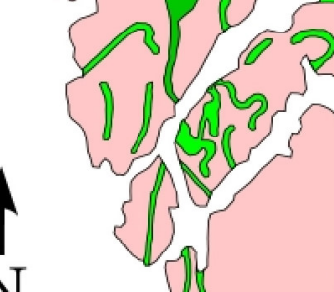

SO
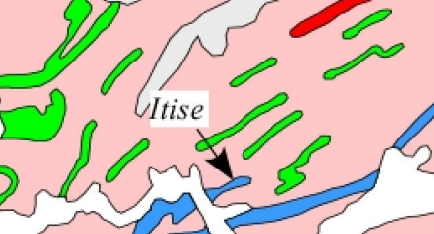

gas 15

$-63^{\circ} \mathrm{N}$ island

$\sqrt{r} \mathbb{R}^{\infty}$
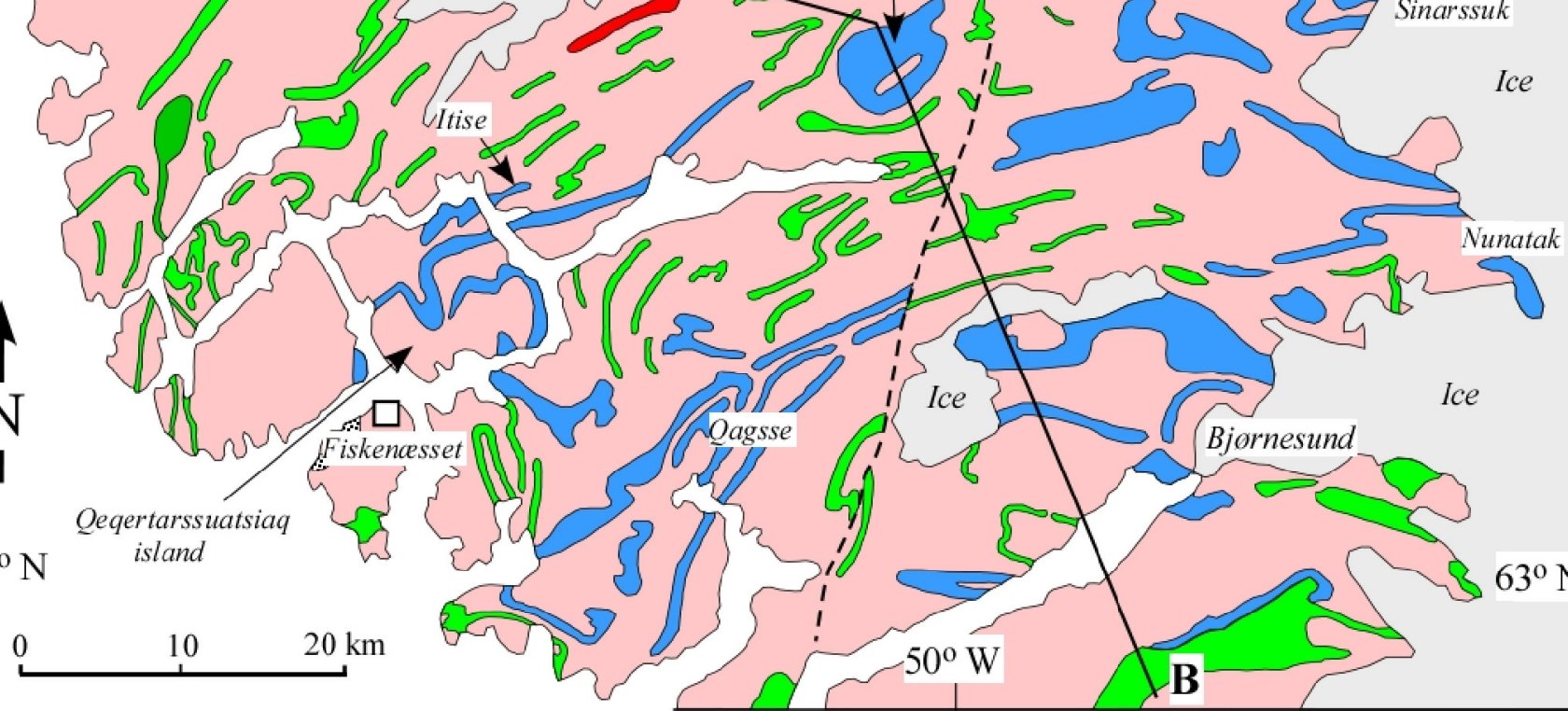

Ice

Ice

$63^{\circ} 15^{\prime} \mathrm{N}$
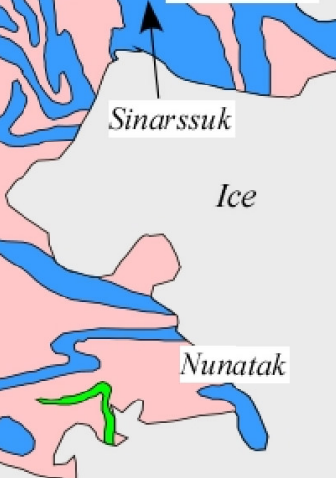

Legend

Granites

TTG gneisses

Fiskenæsset Complex

Amphibolites (basaltic rocks)

Fault _... A-B: Cross-section line 
(a)
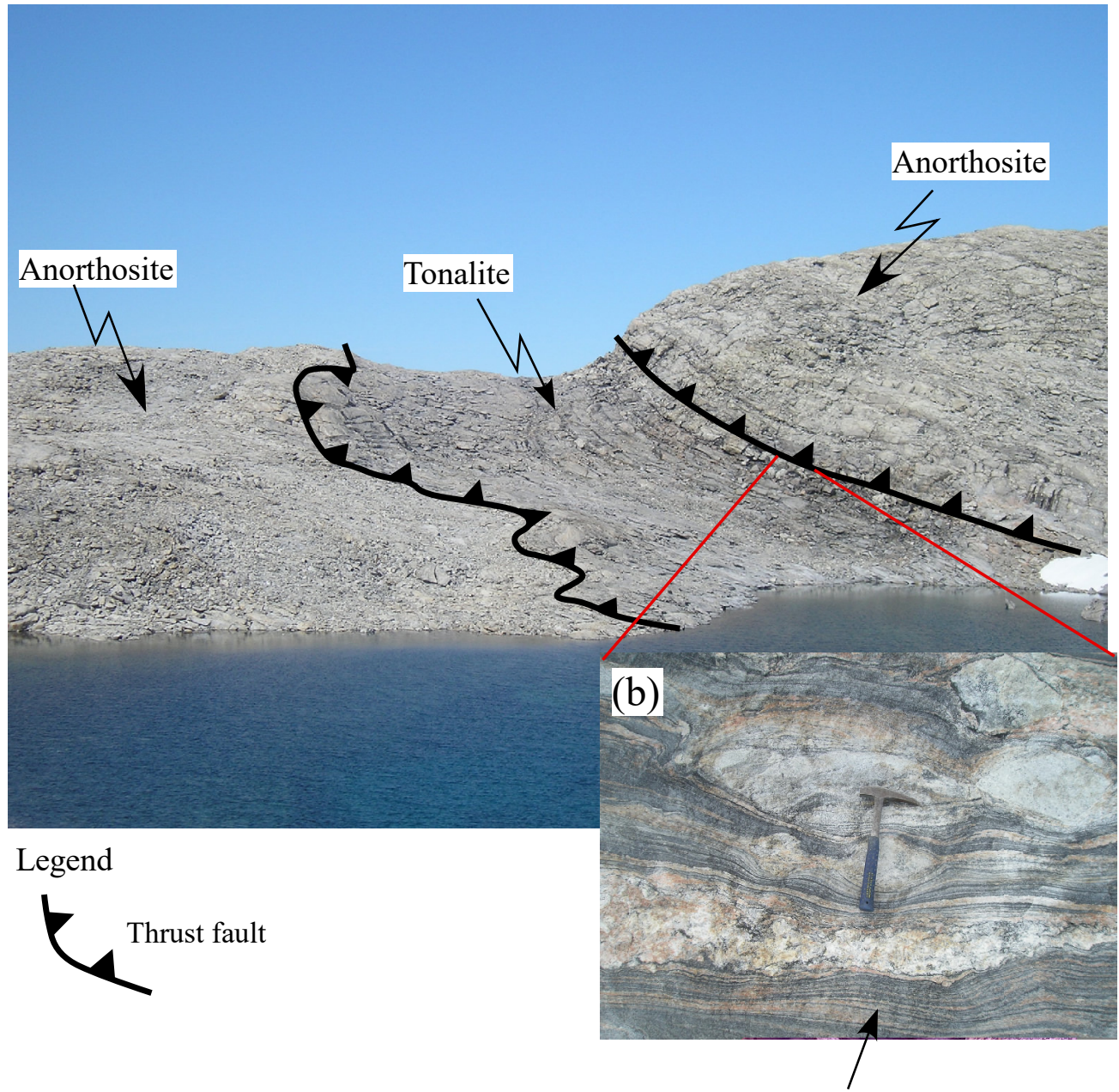

(c)
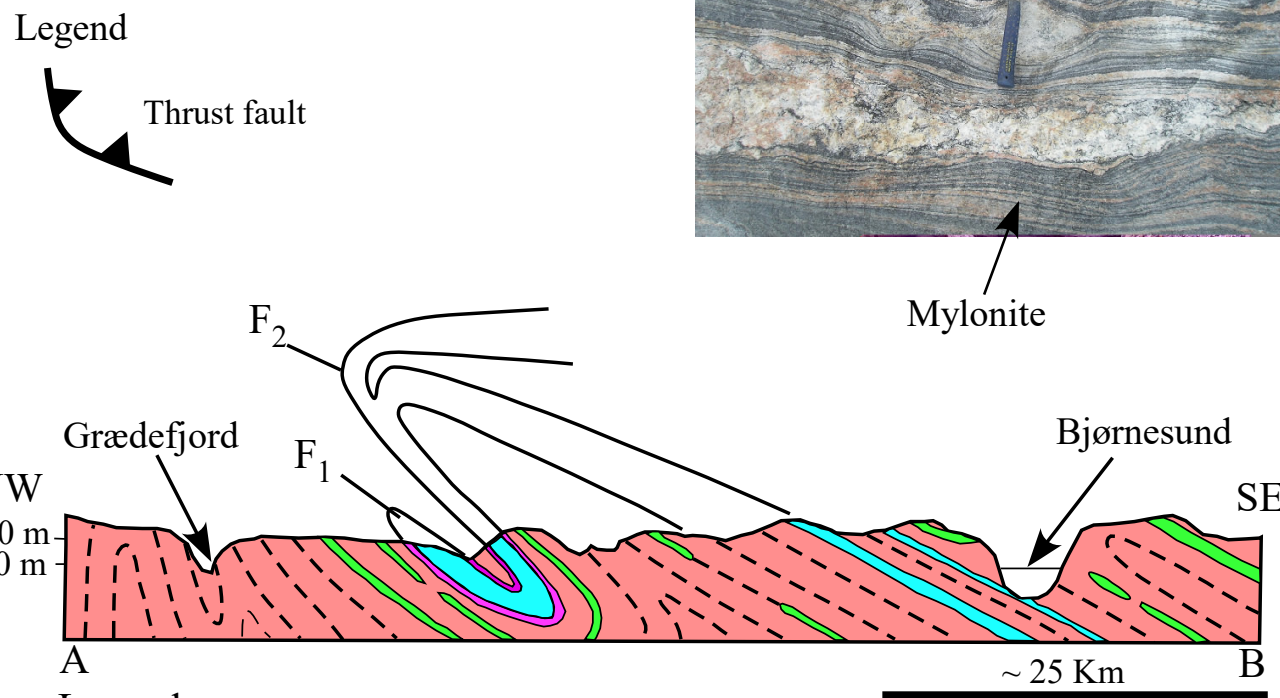

Legend

TTG gneisses $\square$ Fiskenæsset Complex lower section $\square$ Amphibolite

Fiskenæsset Complex upper section 
A Temporal distribution of Tethyan anorthositebearing ophiolites

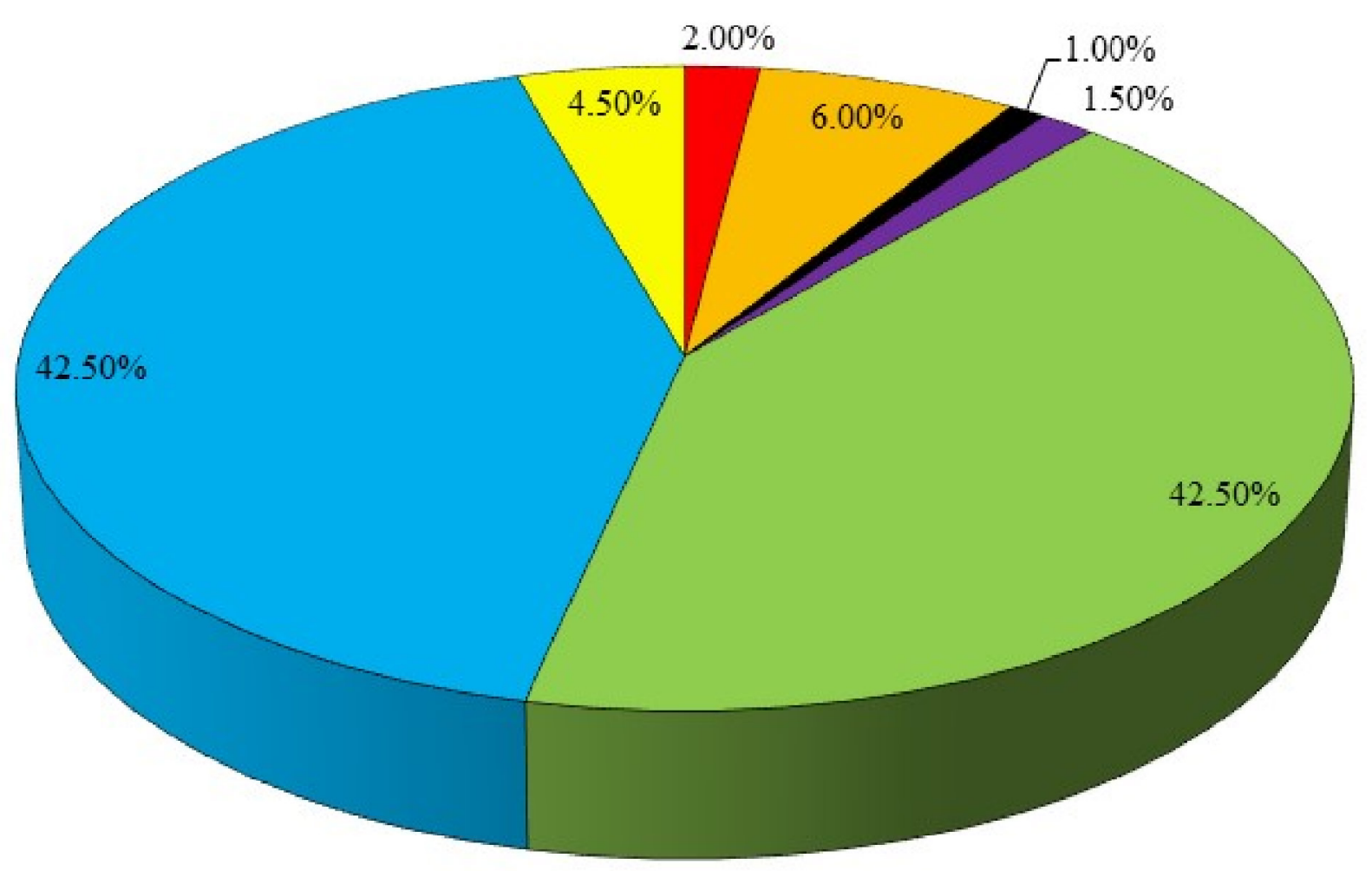

口Devonian

口 Permian

$\square$ Jurassic

$\square$ Paleocene
B Temporal distribution of Archean anorthositebearing layered intrusions

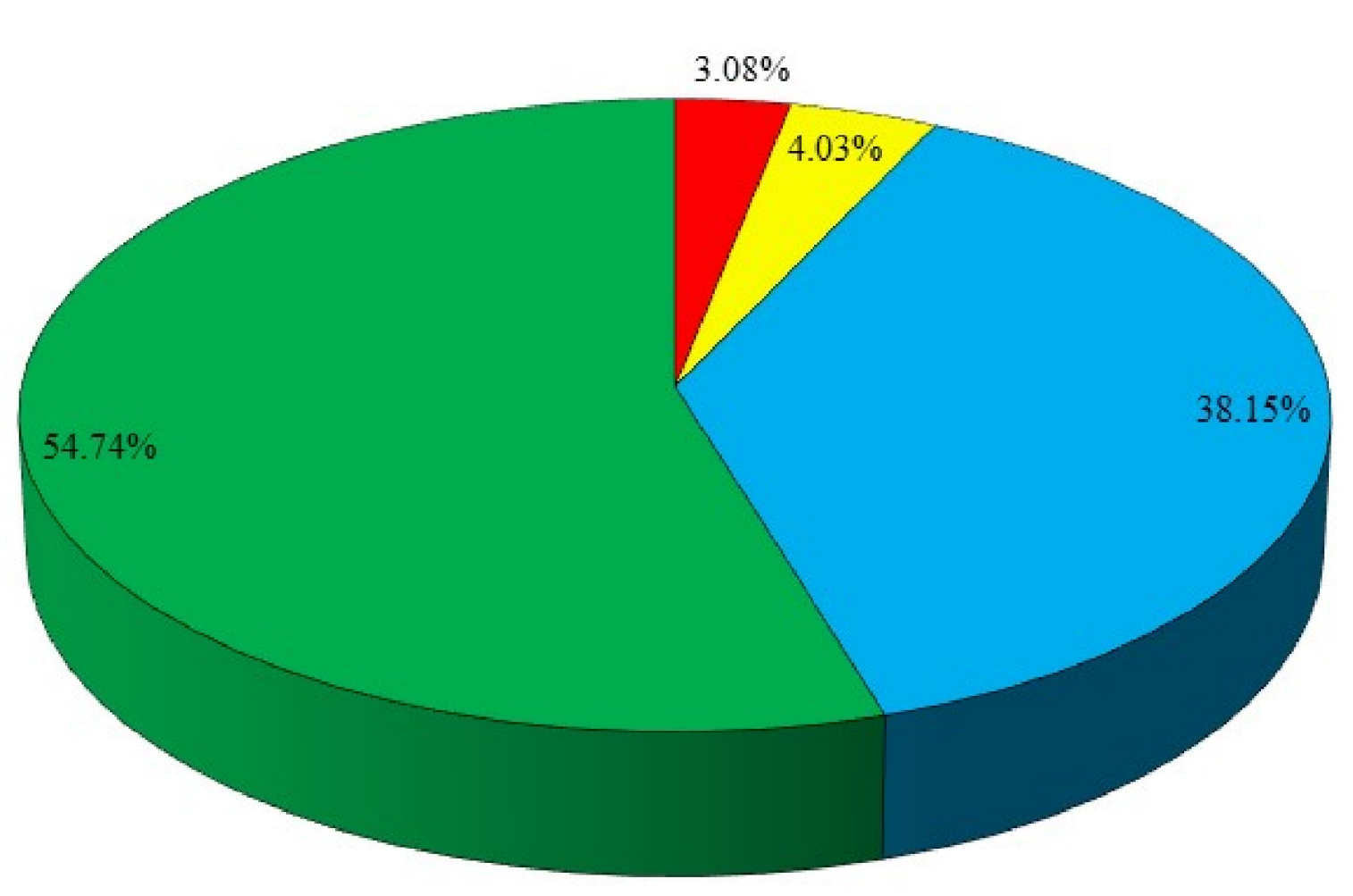

$\square$ Eoarchean $\square$ Paleoarchean $\square$ Mesoarchean $\square$ Neoarchean 
A Geodynamic settings of Tethyan anorthositebearing ophiolites

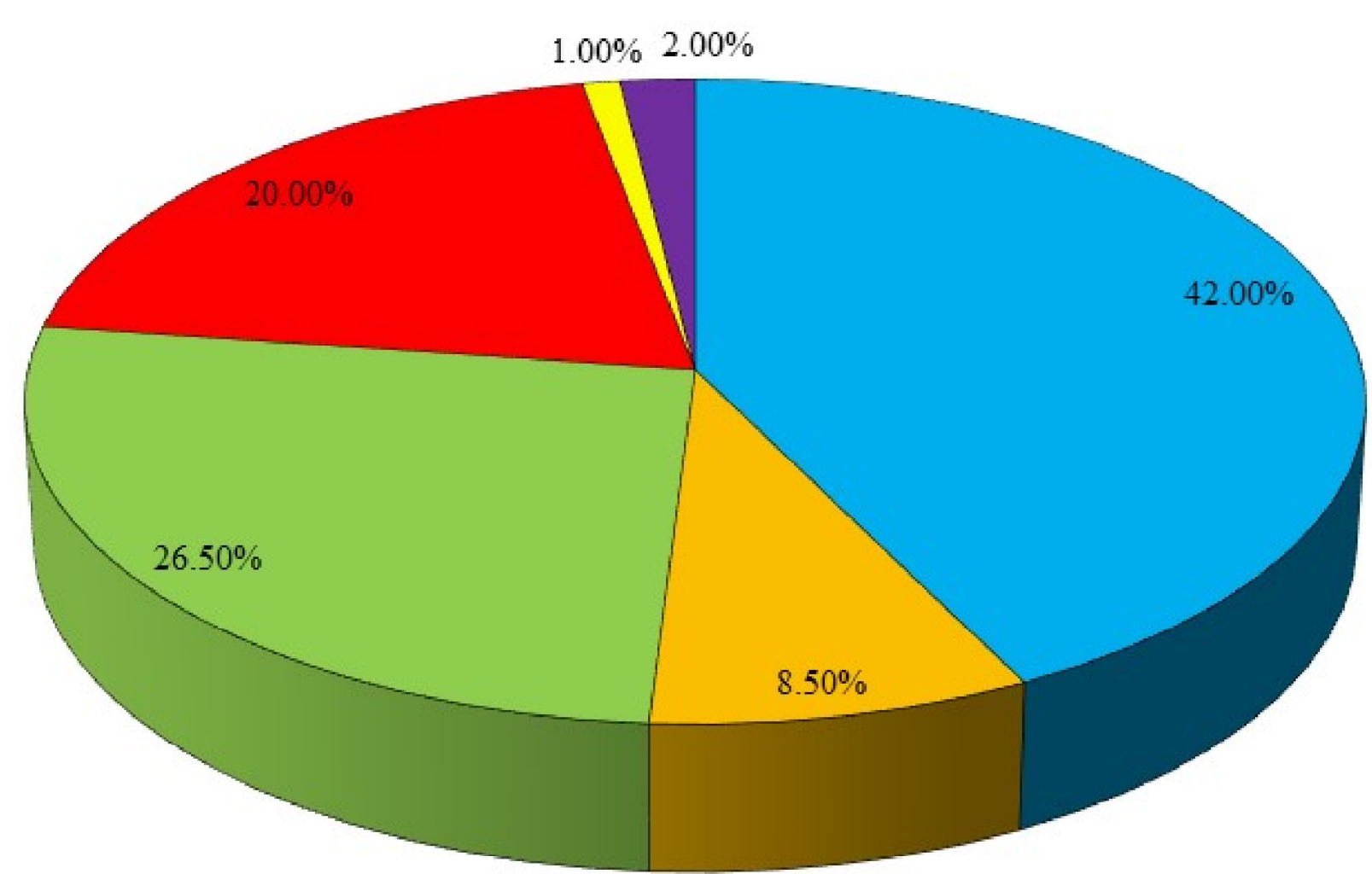

$\square \mathrm{Arc}$

$\square$ Forearc

$\square$ Back-arc

$\square$ Mid-ocean ridge

$\square$ Continental rift

$\square$ Mantle plume
B

Geodynamic settings of Archean anorthositebearing layered intrusions

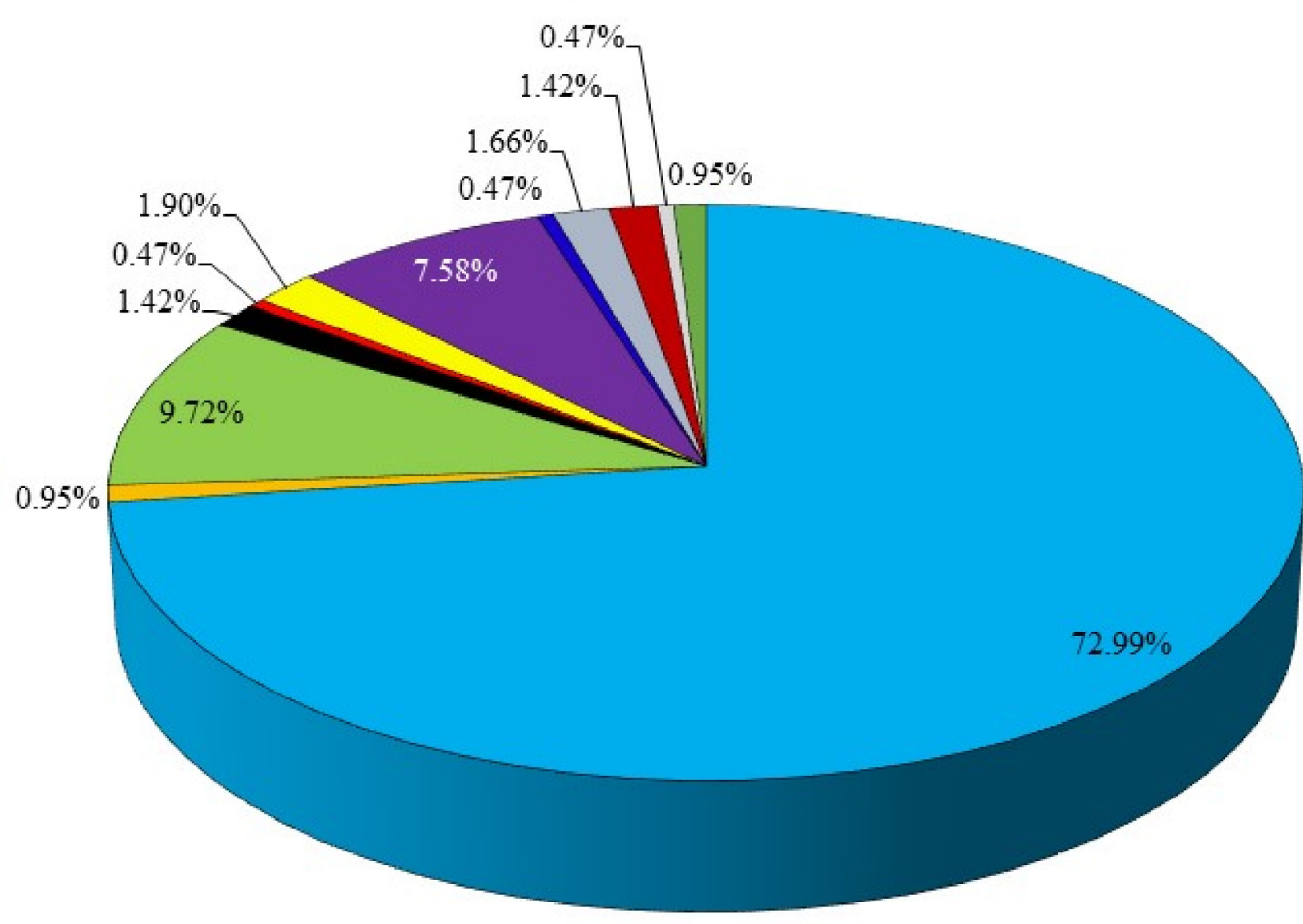

$\square$ Arc

$\square$ Back-arc

$\square$ Mid-ocean ridge

$\square$ Mantle plume

$\square$ Post-orogenic

$\square$ Passive continental margin $\square$ Forearc

- Synorogenic

$\square$ Continental rift

-Oceanic plateau

$\square$ Anorogenic

$\square$ Quasi-platform 
A

Subduction-related versus subductionunrelated Tethyan anorthosite-bearing ophiolites
B

Subduction-related versus subduction-unrelated Archean anorthosite-bearing layered intrusions
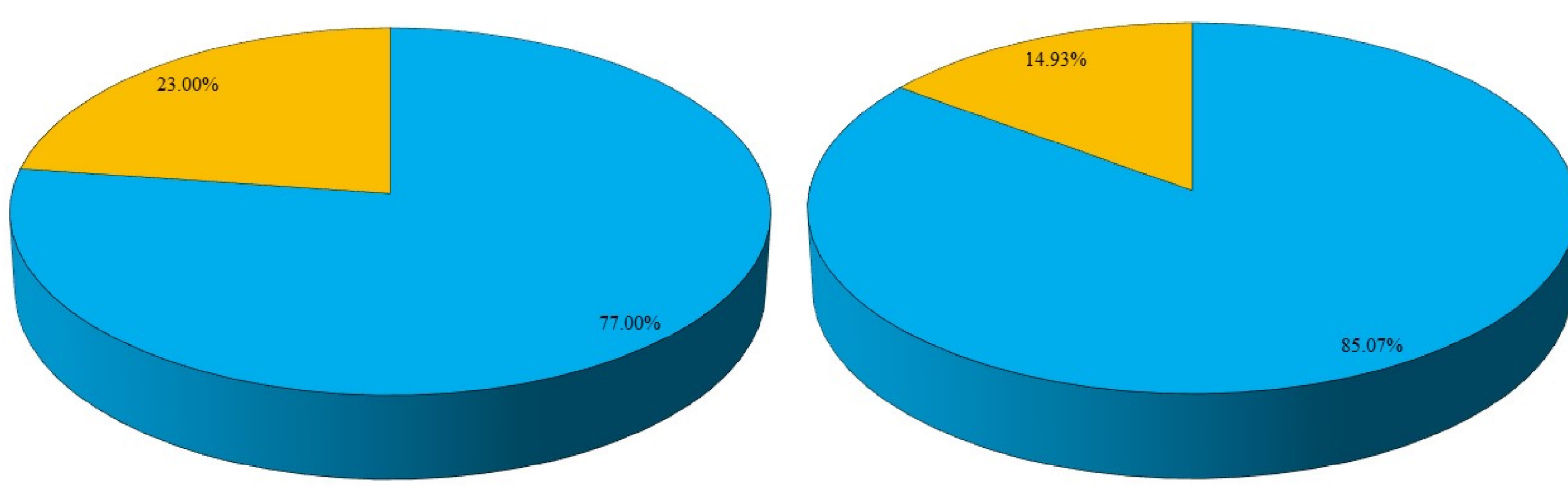

$\square$ Subduction-related

$\square$ Subduction-unrelated

$\square$ Subduction-related

$\square$ Subduction-unrelated 
A Proportion of boninitic versus non-boninitic

Tethyan anorthosite-bearing ophiolites
B Proportion of boninitic versus non-boninitic Archean anorthosite-bearing layered intrusions

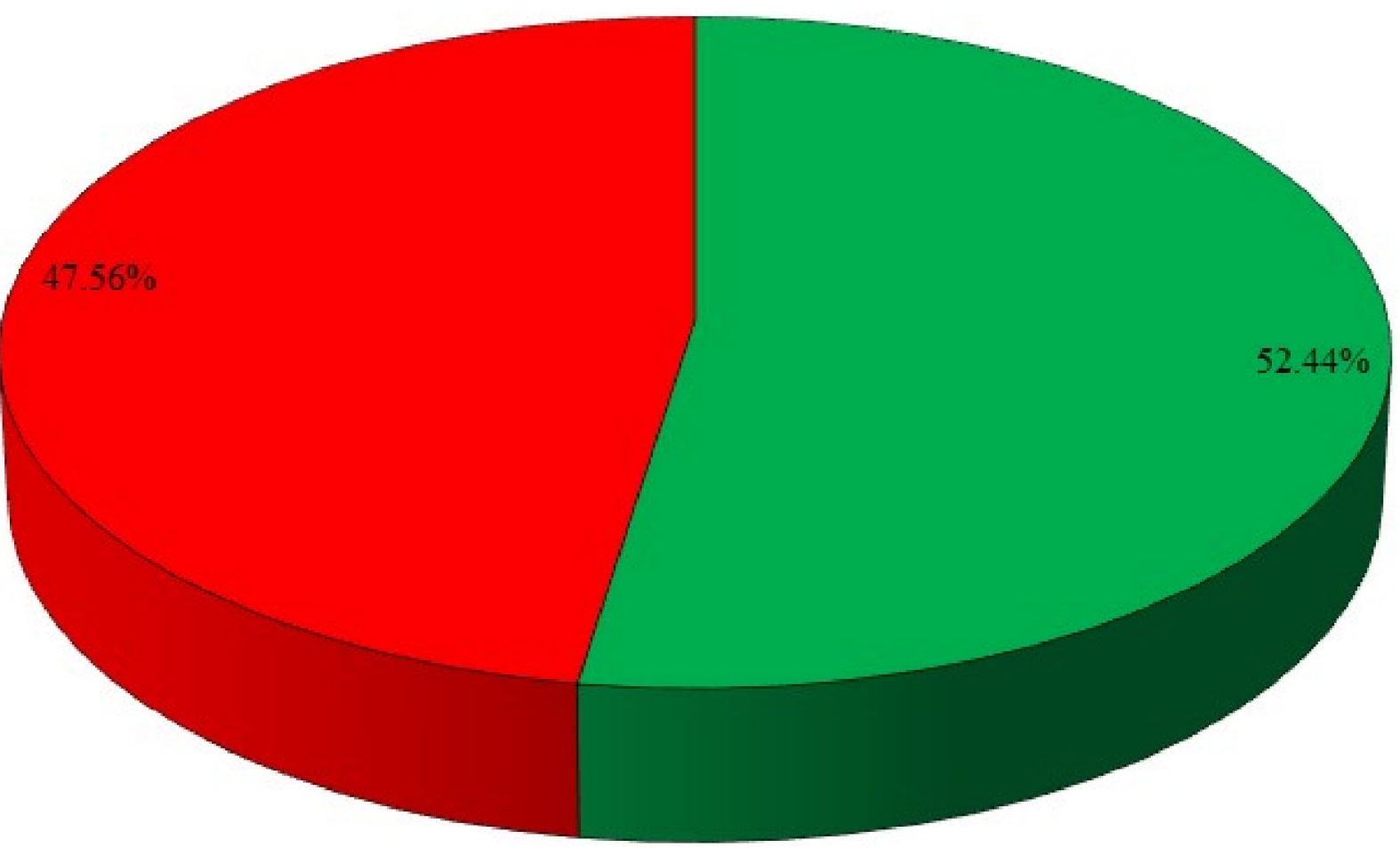

$\square$ Boninitic

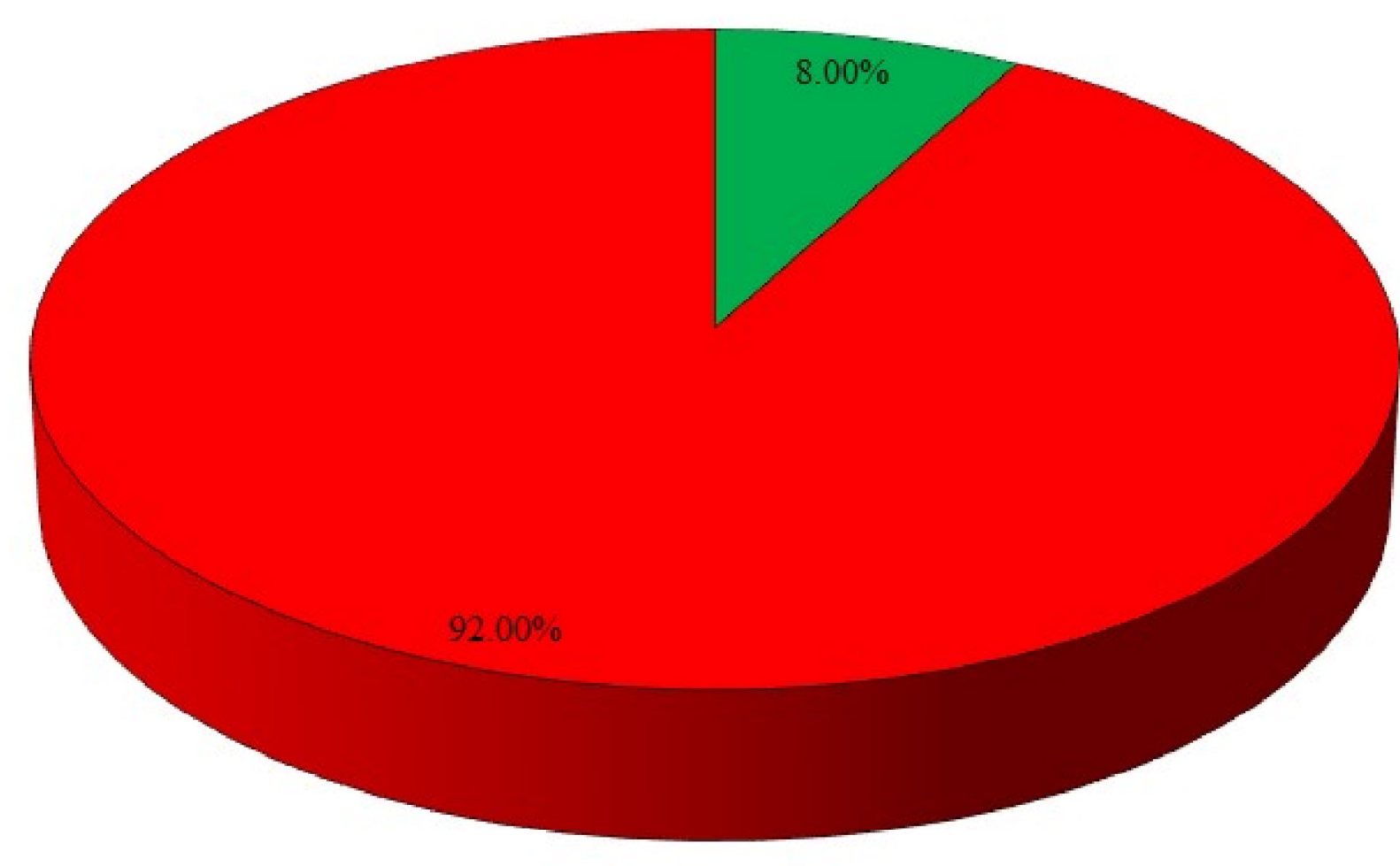

$\square$ Boninitic

-Non-boninitic 
A Tethyan ophiolite-hosted anorthosites by parental magma

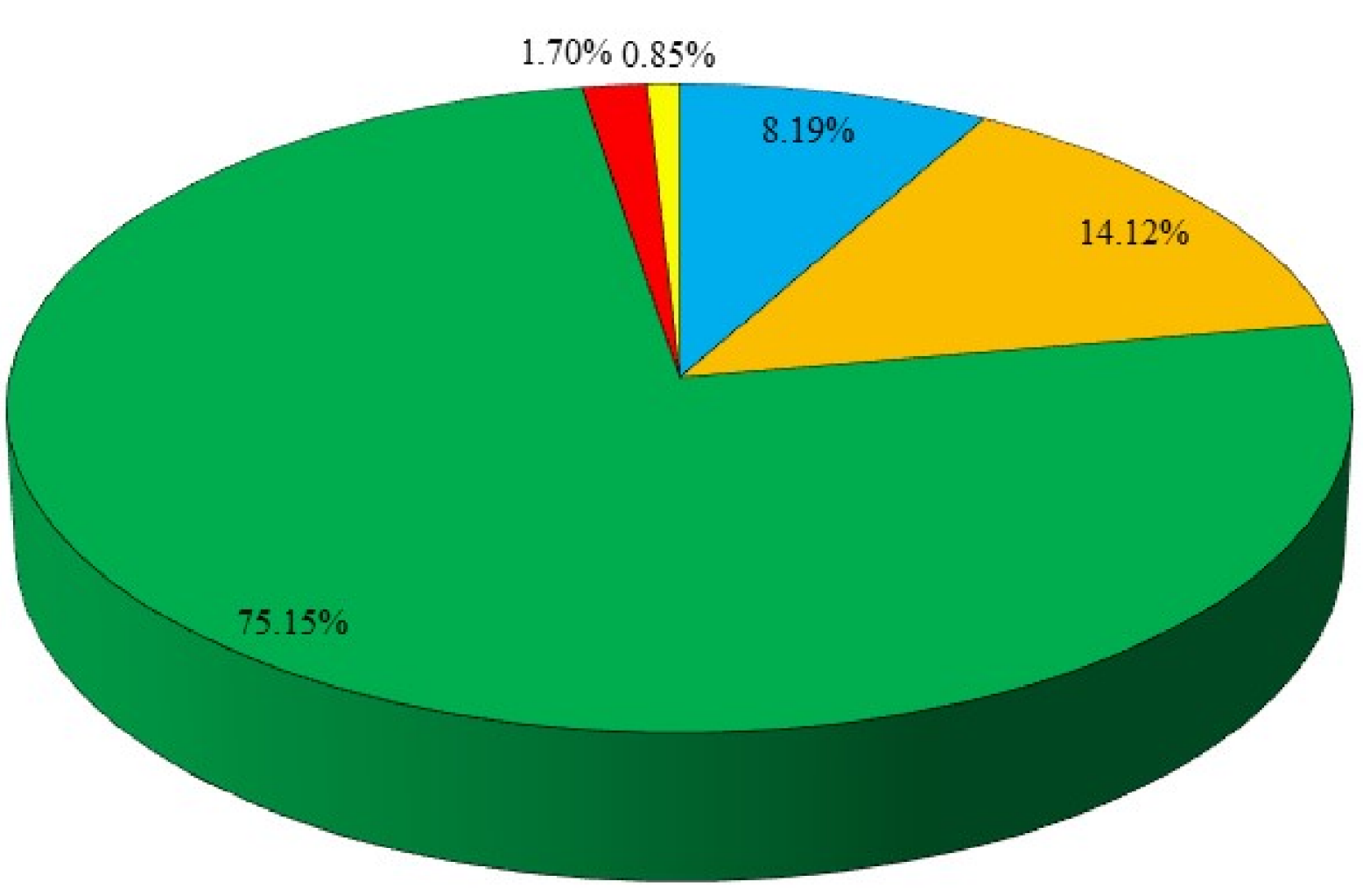

$\square$ Boninitic

$\square$ Island arc tholeiitic/basaltic

$\square$ Tholeiitic/basaltic

$\square$ Calc-alkaline

\section{$\square$ Picritic}

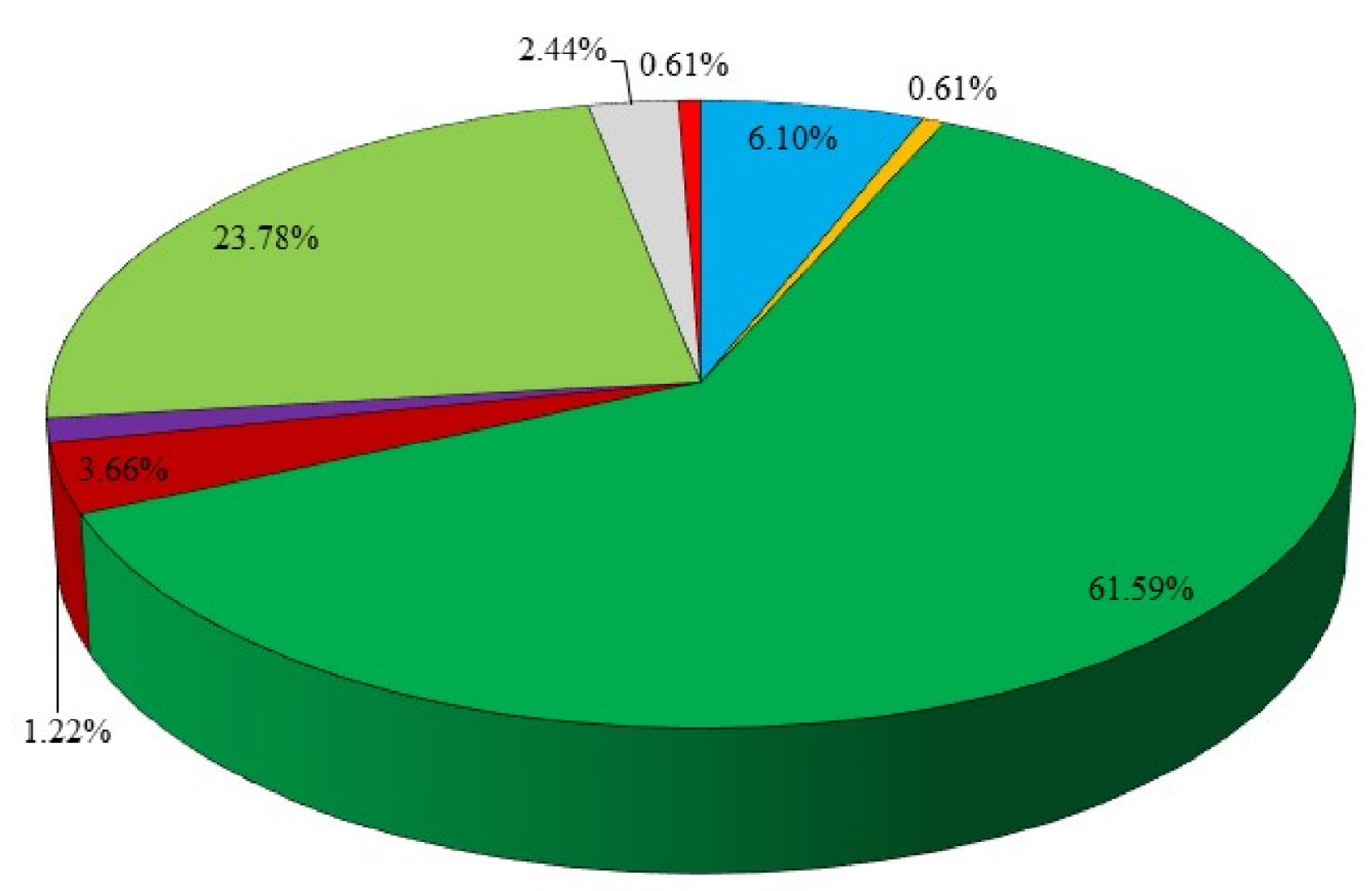

$\square$ Boninitic

$\square$ Tholeiitic/basaltic

$\square$ Komatiitic basaltic

$\square$ High Al tholeiitic $\square$ Island arc tholeiitic/basaltic

- Hydrous tholeiitic/basaltic

$\square$ Hydrous Al-rich tholeiitic

$\square$ Picritic 


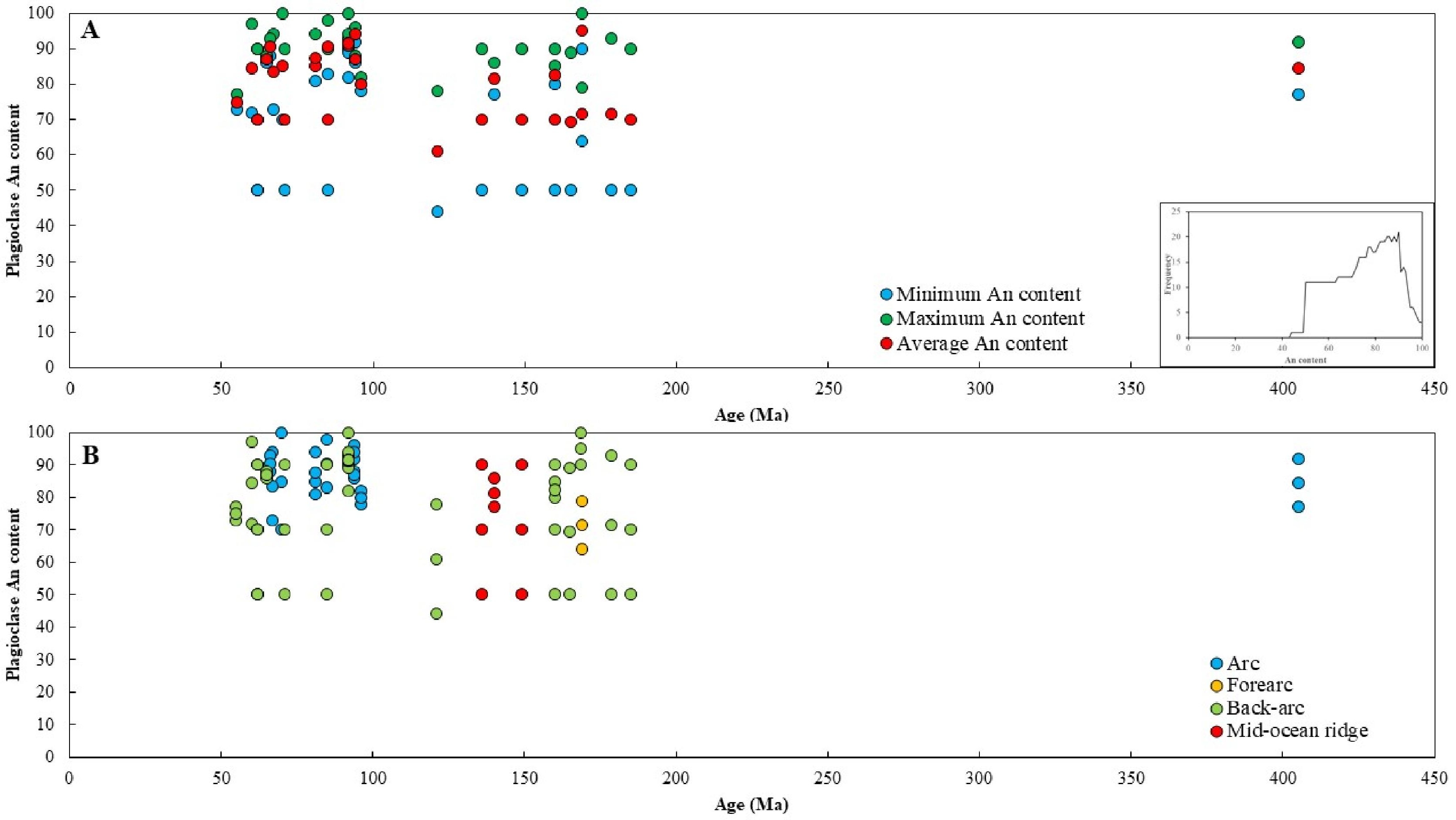




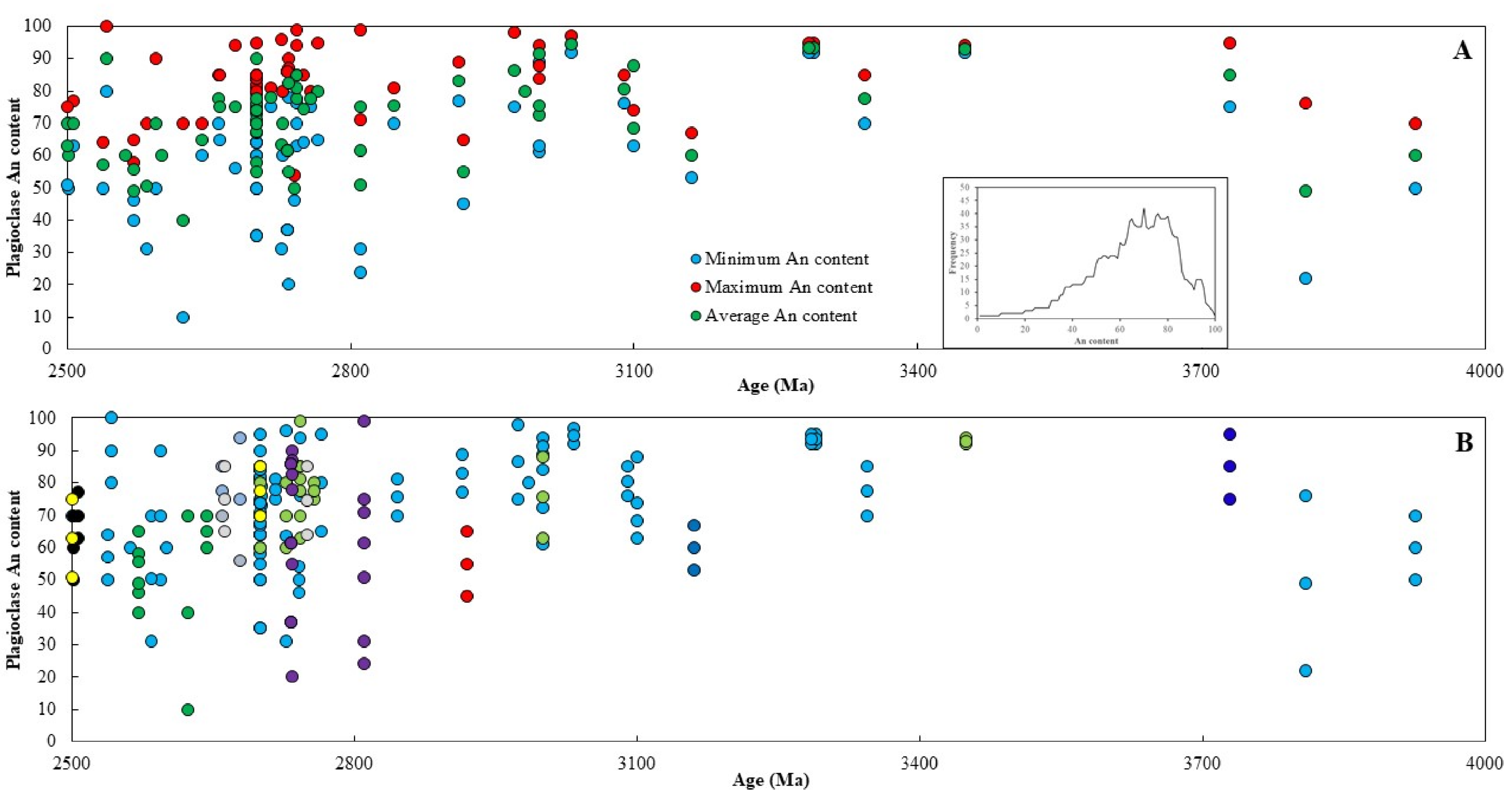

- Arc $\circ$ Back-arc $\bullet$ Synorogenic $\bullet$ Mid-ocean ridge $\odot$ Continental rift $\bullet$ Mantle plume $\bullet$ Oceanic plateau $\odot$ Post-orogenic $\circ$ Anorogenic $\bullet$ Passive continental margin $\circ$ Quasi-platform 
(a) Tethyan anorthosites

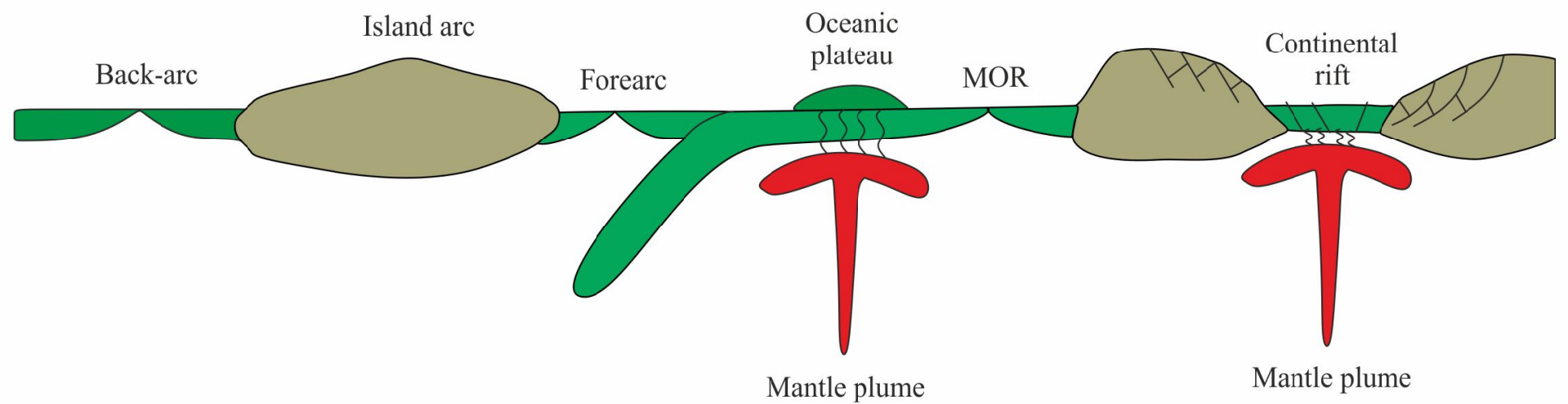

(b) Archean anorthosites

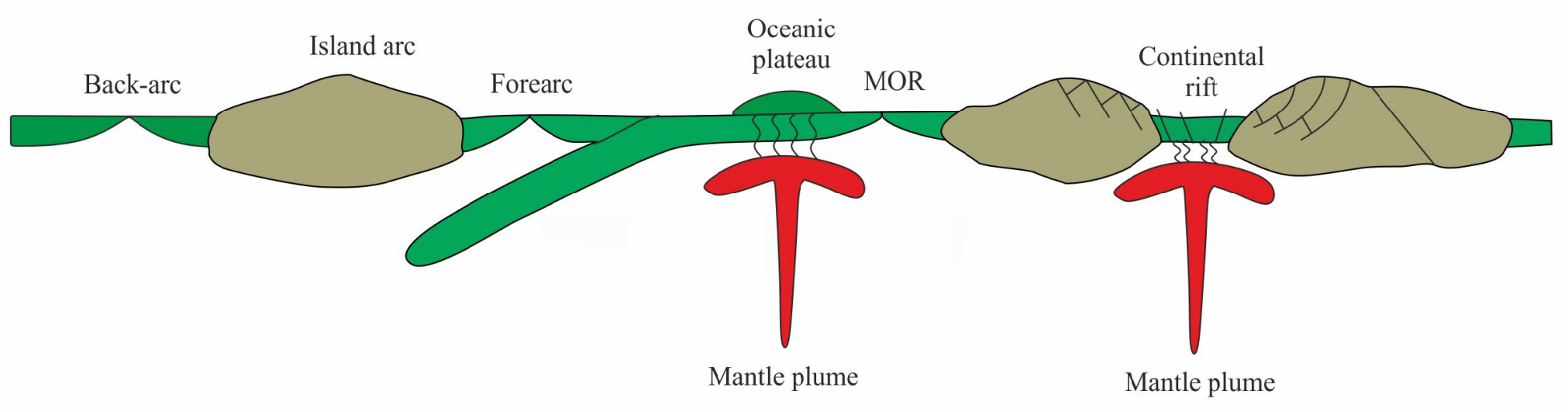


Table 1. A list of the most well-studied major Tethyan anorthosite-bearing ophiolites.

\begin{tabular}{|c|c|c|}
\hline Ophiolite & Age & Absolute Age (Ma) \\
\hline \multicolumn{3}{|l|}{ China } \\
\hline Animaqen & Triassic & \\
\hline Quanzhou & Jurassic & 167 \\
\hline Xigaze & Cretaceous & $124-127$ \\
\hline \multicolumn{3}{|l|}{ Greece } \\
\hline Pili Valley & Jurassic-Triassic & \\
\hline Othrys & Jurassic & 169 \\
\hline Makrirrakhi & Jurassic & 169 \\
\hline Petrota (Evros) & Jurassic & 169 \\
\hline Pindos & Jurassic & 165 \\
\hline \multicolumn{3}{|l|}{ Armenia } \\
\hline Vedi & Jurassic & 178.7 \\
\hline Sevan-Akera & Jurassic & 165 \\
\hline Stepanavan & Jurassic & $\sim 160-168$ \\
\hline \multicolumn{3}{|l|}{ Turkey } \\
\hline Küre & Jurassic & 169 \\
\hline Mersin & Cretaceous & 94 \\
\hline K1zildağ & Cretaceous & 92 \\
\hline Karadağ & Cretaceous & \\
\hline \multicolumn{3}{|l|}{ Albania } \\
\hline Mirdita & Jurassic & 165 \\
\hline \multicolumn{3}{|l|}{ Algeria } \\
\hline Bou-Maïza & Jurassic & \\
\hline \multicolumn{3}{|l|}{ France } \\
\hline Pineto & Jurassic & \\
\hline Monte Maggiore & Jurassic & \\
\hline \multicolumn{3}{|l|}{ Oman } \\
\hline Masirah & Cretaceous & 140 \\
\hline Semail & Cretaceous & 96 \\
\hline \multicolumn{3}{|l|}{ India } \\
\hline Andaman & Cretaceous & 94 \\
\hline Naga Hills & Paleocene-Cretaceous & $\sim 56-72$ \\
\hline \multicolumn{3}{|l|}{ Iran } \\
\hline Neyriz & Cretaceous & 92 \\
\hline \multicolumn{3}{|l|}{ Cyprus } \\
\hline Troodos & Cretaceous & 92 \\
\hline \multicolumn{3}{|l|}{ Pakistan } \\
\hline Chilas Complex & Cretaceous & 85 \\
\hline Muslim Bagh & Cretaceous-Jurassic & $65-87 ; 118-157$ \\
\hline \multicolumn{3}{|l|}{$\operatorname{Iraq}$} \\
\hline Mawat & Cretaceous & $81-95$ \\
\hline
\end{tabular}


Table 2. A list of the most well-studied major Archean anorthosite-bearing layered intrusions.

\begin{tabular}{|c|c|c|}
\hline Layered intrusion & Age & Absolute Age (Ma) \\
\hline \multicolumn{3}{|l|}{ Canada } \\
\hline Shawmere & Neoarchean & 2765 \\
\hline Pipestone Lake & Neoarchean & 2758 \\
\hline Bird River & Neoarchean & 2743 \\
\hline Euclid Lake & Neoarchean & 2743 \\
\hline Mayville & Neoarchean & 2742.8 \\
\hline Doré Lake & Neoarchean & 2728 \\
\hline Ring of Fire & Neoarchean & $2727-2734$ \\
\hline Bad Vermilion Lake & Neoarchean & 2716 \\
\hline Bell River & Neoarchean & $>2700$ \\
\hline Cauchon Lake & Neoarchean & $>2700$ \\
\hline Love Lake & Neoarchean & $\sim 2562$ \\
\hline Big Trout Lake & Neoarchean & $>2500$ \\
\hline \multicolumn{3}{|l|}{ Greenland } \\
\hline Ivisaartoq & Mesoarchean & 3075 \\
\hline Naajat Kuuat & Mesoarchean & 2985 \\
\hline Fiskenæsset & Mesoarchean & 2973 \\
\hline Nunataarsuk & Mesoarchean & 2914 \\
\hline Storø & Mesoarchean & $2800-3060$ \\
\hline Fredrikshåb & Neoarchean & $>2700$ \\
\hline Uivak & Neoarchean & 2698 \\
\hline \multicolumn{3}{|l|}{ Scotland } \\
\hline Isle of Lewis & Mesoarchean & $>3000$ \\
\hline Ness & Mesoarchean & $>3000$ \\
\hline South Harris & Mesoarchean & $>3000$ \\
\hline Loch Laxford & Mesoarchean & $<3000$ \\
\hline \multicolumn{3}{|l|}{ India } \\
\hline Holenarasipir & Paleoarchean & $3285-3290$ \\
\hline Nuasahi & Mesoarchean & $3119-3123$ \\
\hline Badampahar & Mesoarchean & 3090 \\
\hline Bhavani & Mesoarchean & 2898 \\
\hline Agali Hill & Neoarchean & 2547 \\
\hline Sittampundi & Neoarchean & 2541 \\
\hline Devanur & Neoarchean & $2528-2545$ \\
\hline \multicolumn{3}{|l|}{ Western Australia } \\
\hline Manfred & Eoarchean & 3730 \\
\hline Andover & Mesoarchean & 3016 \\
\hline Millindinna & Mesoarchean & $2950-2970$ \\
\hline Munni Munni & Mesoarchean & 2925 \\
\hline Windimurra & Mesoarchean & 2813 \\
\hline
\end{tabular}


Onverwacht

Messina

Stella

Brazil

Lagoa da Vaca

Senador Elói de Souza

Rio Jararé

São José do Jacuipe

United States of America
Paleoarchean

Paleoarchean

Mesoarchean

Mesoarchean

Mesoarchean

Mesoarchean

Neoarchean

Neoarchean
3450

3344

3033.5

3161

3033

2841

2583.7 
Table 3. Evidence presented in the literature for the different geodynamic settings prop

\begin{tabular}{|c|c|c|}
\hline Evidence & $\operatorname{Arc}(\mathrm{T} / \mathrm{A})$ & Mid-ocean ridge (T/A) \\
\hline \multirow[t]{3}{*}{ Geochemistry } & Negative $\mathrm{Nb}$ and $\mathrm{Ti}$ anomalies; & Absence of negative \\
\hline & $\begin{array}{l}\text { Narrow-ranging low } \mathrm{Th} / \mathrm{Nb} \\
\text { and } \mathrm{La} / \mathrm{Nb} \text { ratios }\end{array}$ & $\begin{array}{l}\mathrm{Nb} \text { and } \mathrm{Ti} \text { anomalies; } \\
\text { Low } \mathrm{TiO}_{2} / \mathrm{Yb} \text { and }\end{array}$ \\
\hline & & $\mathrm{Nb} / \mathrm{Yb}$ ratios \\
\hline Chromite chemistry & Arc-related & MORB-related \\
\hline Field relationships & $\begin{array}{l}\text { Spatially and temporally } \\
\text { associated with arc pyroclastic, } \\
\text { massive and pillowed volcanic } \\
\text { and plutonic rocks }\end{array}$ & $\begin{array}{l}\text { Spatially and temporally } \\
\text { associated with MORB } \\
\text { volcanic and plutonic } \\
\text { rocks }\end{array}$ \\
\hline Mineralogy & $\begin{array}{l}\text { Calcic plagioclase }\left(\mathrm{An}_{80-100}\right) \\
\text { Magmatic amphibole }\end{array}$ & \\
\hline Crustal contamination & Minimal to significant & None \\
\hline
\end{tabular}


osed for Tethyan (T) and Archean (A) anorthosites.

\begin{tabular}{|c|c|c|}
\hline Rift (T/A) & Mantle plume (T/A) & Oceanic plateau (A) \\
\hline $\begin{array}{l}\text { High } \mathrm{La} / \mathrm{Yb}, \mathrm{Nd} / \mathrm{Sm} \\
\text { and } \mathrm{Zr} / \mathrm{Y} \text { ratios }\end{array}$ & $\begin{array}{l}\text { High } \mathrm{TiO}_{2} / \mathrm{Yb} \text { and } \mathrm{Nb} / \mathrm{Yb} \\
\text { ratios }\end{array}$ & $\begin{array}{l}\mathrm{High} \mathrm{TiO}_{2} / \mathrm{Yb} \text { and } \mathrm{Nb} / \mathrm{Yb} \\
\text { ratios }\end{array}$ \\
\hline $\begin{array}{l}\text { Emplaced into older } \\
\text { gneisses; Spatially } \\
\text { and temporally } \\
\text { associated with } \\
\text { clastic sedimentary } \\
\text { and volcanic rocks }\end{array}$ & $\begin{array}{l}\text { Spatially and temporally } \\
\text { associated with komatiites, } \\
\text { komatiitic basalts and picrites }\end{array}$ & $\begin{array}{l}\text { Oceanic plateau-related } \\
\text { Spatially and temporally } \\
\text { associated with komatiites } \\
\text { and komatiitic basalts }\end{array}$ \\
\hline Significant & None to significant & None to significant \\
\hline
\end{tabular}




Synorogenic (A) $\quad$ Anorogenic/post-orogenic (A)

High La/Yb, Nd/Sm High La/Yb, Nd/Sm

and $\mathrm{Zr} / \mathrm{Y}$ ratios and $\mathrm{Zr} / \mathrm{Y}$ ratios

$\begin{array}{ll}\begin{array}{l}\text { Emplaced into older } \\ \text { gneisses }\end{array} & \begin{array}{l}\text { Emplaced into older } \\ \text { gneisses }\end{array}\end{array}$ 


\section{QAGUPUBLICATIONS}

[Tectonics]

Supporting Information for

[Comparisons between Tethyan Anorthosite-bearing Ophiolites and Archean Anorthosite-bearing Layered Intrusions: Implications for Archean Geodynamic Processes]

[Paul Sotiriou and Ali Polat]

[University of Windsor]

\section{Contents of this file}

Figures $\mathrm{S} 1$ to $\mathrm{S} 4$

Tables S1 to S2

Figure S1. Map showing the distribution and ages of Tethyan anorthosite-bearing ophiolites in Italy, France, Corsica, and the Balkans (modified after Dilek and Furnes, 2009).

Figure S2. Map showing the distribution and ages of Tethyan anorthosite-bearing ophiolites in the Balkans, Greece, Cyprus, Turkey, Armenia, and the Middle East (modified after Dilek and Furnes, 2009).

Figure S3. Map showing the distribution and ages of Tethyan anorthosite-bearing ophiolites in Iran and Oman (modified after Dilek and Furnes, 2009).

Figure S4. Map showing the distribution and ages of Tethyan anorthosite-bearing ophiolites in the Himalayas (modified after Dilek and Furnes, 2009).

Table S1. Tethyan anorthosite-bearing ophiolite occurrences.

Table S1. Archean anorthosite-bearing layered intrusion occurrences. 
Tethyan anorthosite-bearing ophiolites:
$\mathrm{f}_{\mathrm{N}}$
Jurassic
Cretaceous
Paleocene

$-44^{\circ} \mathrm{N}$

$-40^{\circ} \mathrm{N}$

$-42^{\circ} \mathrm{N}$
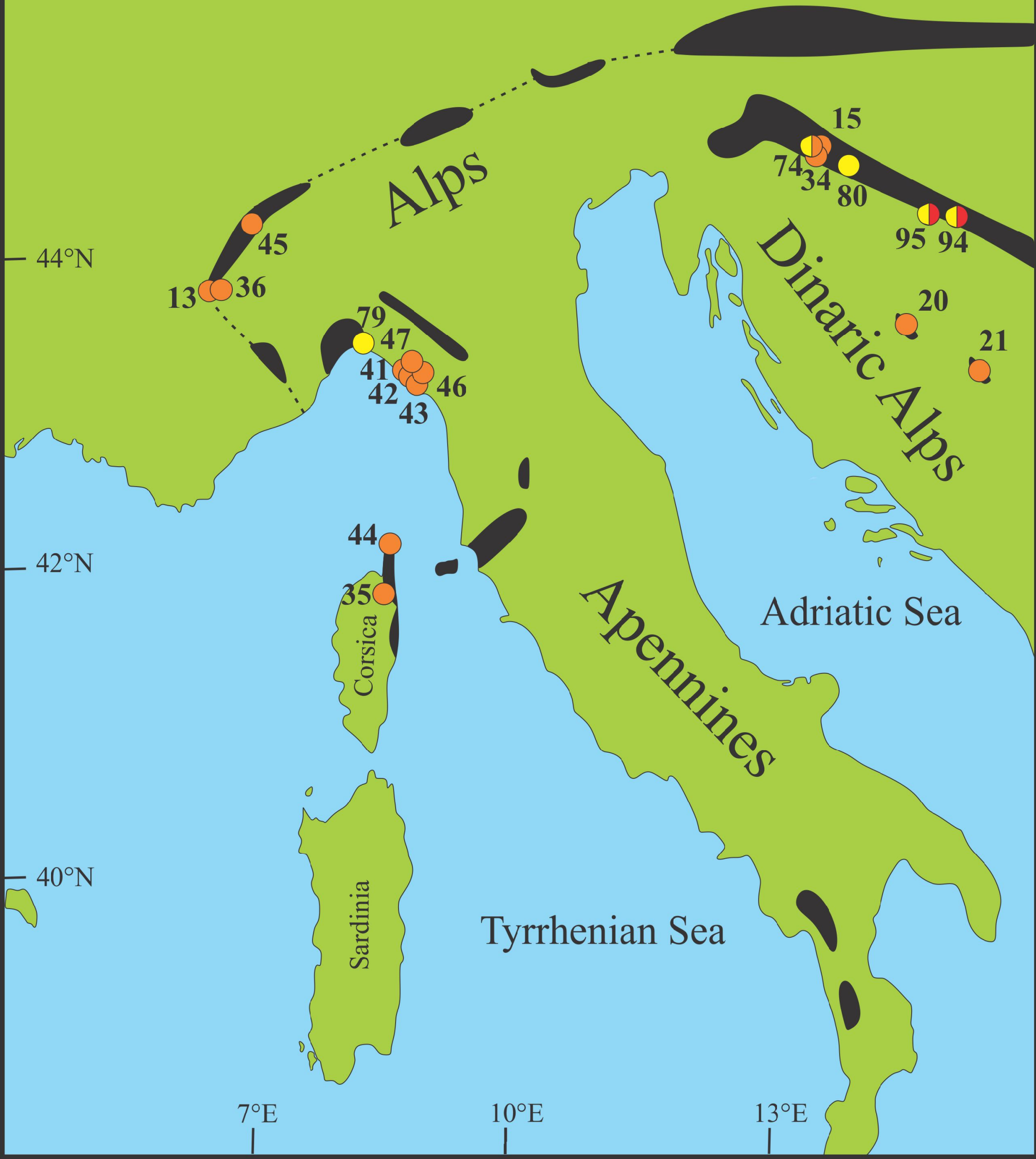


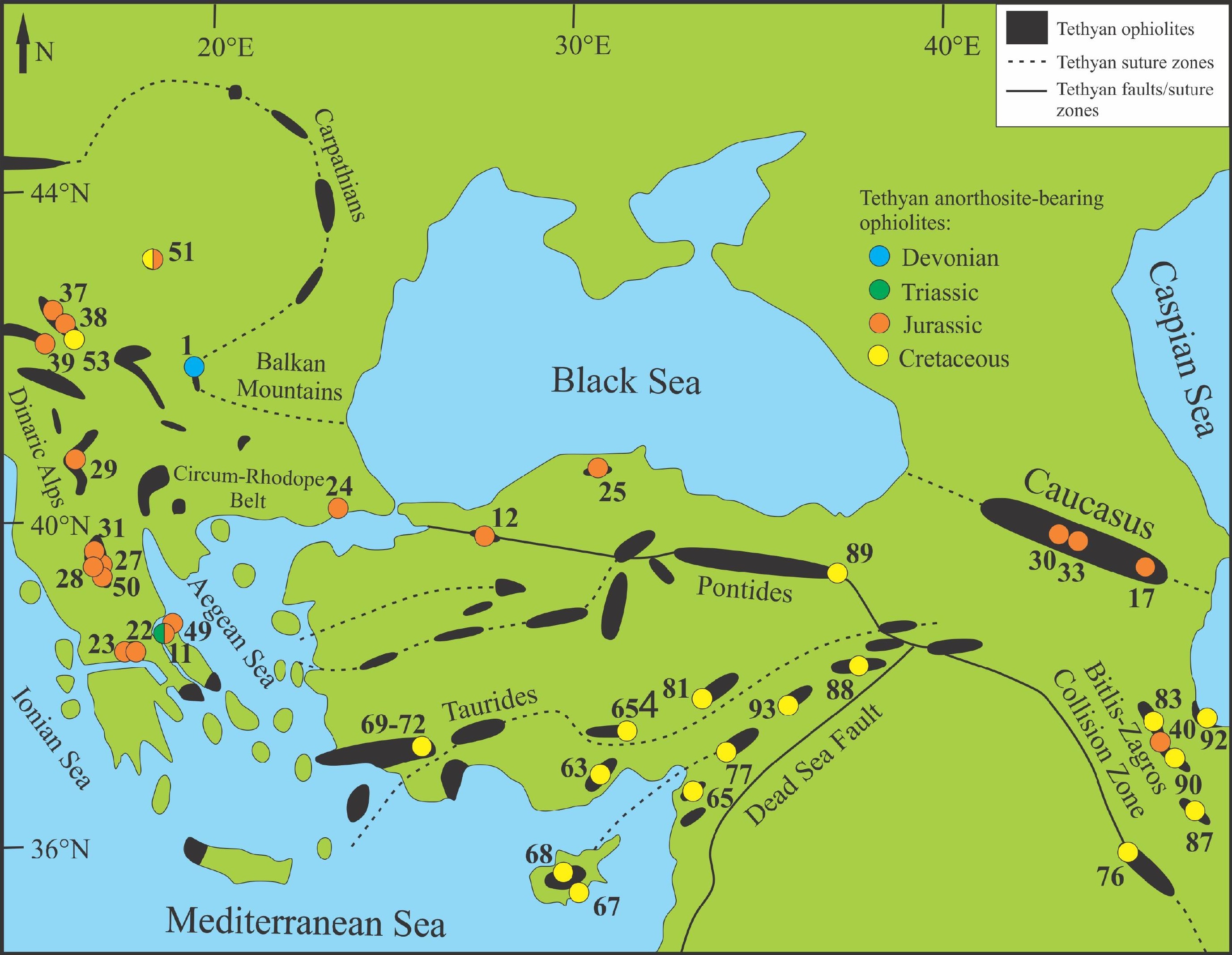




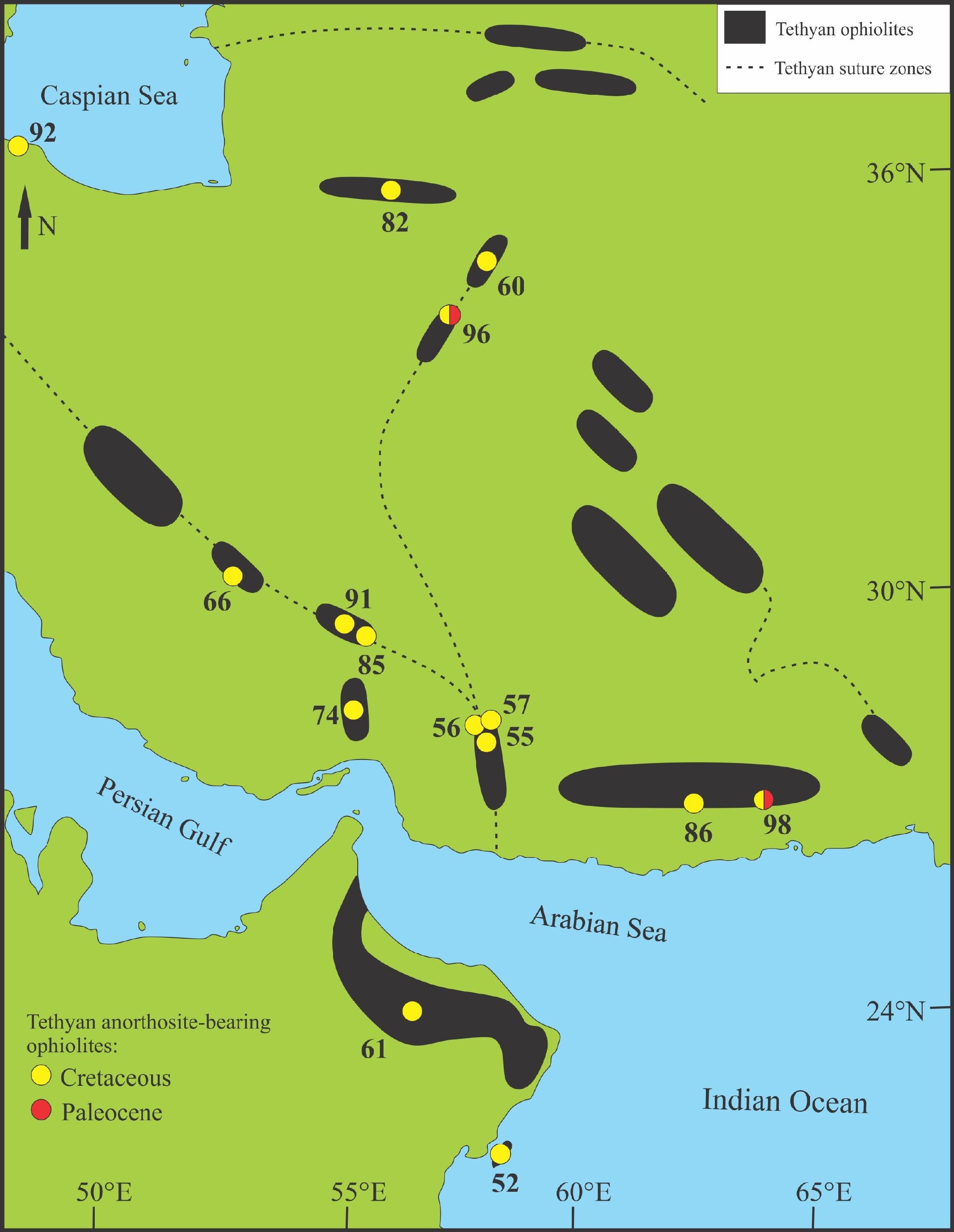




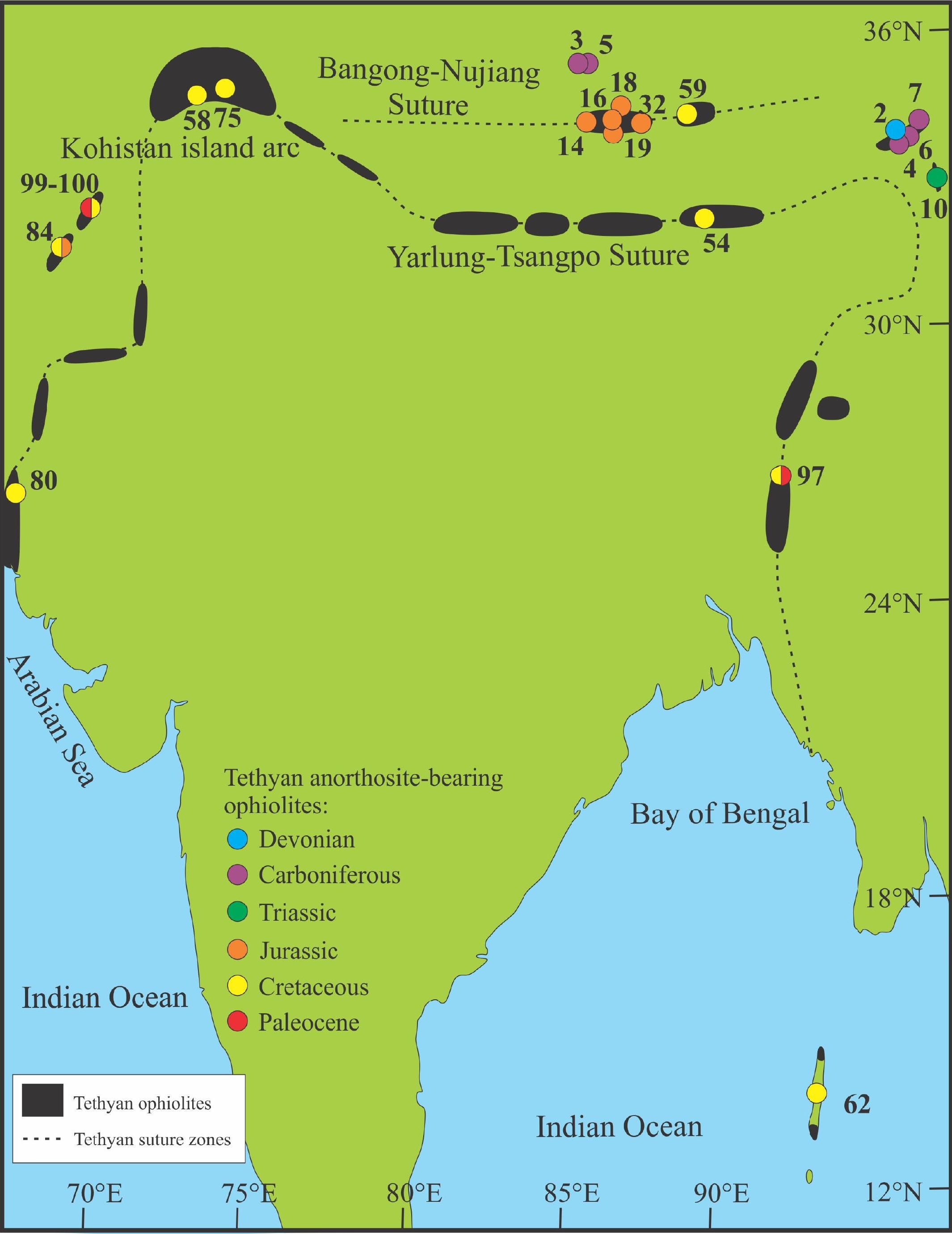


Table S1. Tethyan anorthosite-bearing ophiolite occurrences.

\begin{tabular}{|c|c|c|c|c|}
\hline Ophiolite & Location & Age & Age (Ma) & Size $\left(\mathrm{km}^{2}\right)$ \\
\hline 1. Deli Jovan & Serbia & Devonian & $405-406$ & $\sim 300$ \\
\hline 2. Jinshajjiang-Ailaoshan suture belt & China & Devonian & $374-387$ & \\
\hline 3. East Gangma Co & China & Carboniferous & $354-357$ & \\
\hline 4. Dongzhulin & China & Carboniferous & 347 & 3-4 kilometres wide \\
\hline 5. Guoganijanian & China & Carboniferous & 345 & 90 \\
\hline 6. Jingshajjiang & China & Carboniferous & $329-346$ & 12000 \\
\hline 7. Shusong (Jinsha River) (2 occurrences) & China & Carboniferous & $329-340$ & \\
\hline 8. Wusnihei (Hegenshan) & China & Carboniferous & 300 & $\sim 80$ \\
\hline 9. Chaogenshan (Hegenshan) & China & Permian & 298 & \\
\hline 10. Animaqen & China & Triassic (minimum age) & & \\
\hline 11. Pili Valley & Greece & Jurassic-Triassic & & \\
\hline 12. Bolu & Turkey & Jurassic & & \\
\hline 13. Montgènevre & France & Jurassic & 198 & \\
\hline 14. Dongco & China & Jurassic & 187 & \\
\hline 15. Mt. Kalnik & Croatia & Jurassic & 185-189 & \\
\hline 16. Dongqiao & China & Jurassic & 184 & \\
\hline 17. Vedi & Armenia & Jurassic & 178.7 & \\
\hline 18. Amdo & China & Jurassic & 177 & \\
\hline 19. Beila & China & Jurassic & $172-184$ & $\sim 400$ \\
\hline 20. Borja & Bosnia and Herzegovina & Jurassic & 171 & \\
\hline 21. Krivaja-Konjuh & Bosnia and Herzegovina & Jurassic & 171 & $\sim 2000$ \\
\hline 22. Makrirrakhi & Greece & Jurassic & 169 & \\
\hline 23. Othrys & Greece & Jurassic & 169 & 1500 \\
\hline 24. Petrota (Evros) & Greece & Jurassic & 169 & 16 \\
\hline 25. Küre & Turkey & Jurassic & 168.8 & $\sim 150$ \\
\hline 26. Quanzhou & China & Jurassic & 167 & \\
\hline 27. Aspropotamos (Pindos) & Greece & Jurassic & 165 & Several kilometres long \\
\hline 28. Dramalas (Pindos) & Greece & Jurassic & 165 & 1200 \\
\hline 29. Mirdita & Albania & Jurassic & 165 & \\
\hline 30. Sevan-Akera & Armenia & Jurassic & 165 & \\
\hline 31. Smolicas Mountains (Pindos) & Greece & Jurassic & 165 & 100 \\
\hline 32. Dengqen & China & Jurassic & 164 & \\
\hline 33. Stepanavan & Armenia & Jurassic & $\sim 160-168$ & \\
\hline 34. Banovina & Croatia & Jurassic & $160-166$ & \\
\hline 35. Pineto & Corsica (France) & Jurassic & & $\sim 10$ \\
\hline 36. Chenaillet & France/Italy & Jurassic & $153-165$ & \\
\hline 37. Brezovica & Serbia & Jurassic & $149-192$ & \\
\hline 38. Bistrica & Serbia & Jurassic & $148-163$ & \\
\hline 39. Zlatibor & Serbia & Jurassic & $148-163$ & \\
\hline 40. Kangareh mafic intrusion & Iran & Jurassic & 148 & $\sim 25$ \\
\hline 41. Bracco & Italy & Jurassic & & \\
\hline 42. Bracco Gabbro Complex & Italy & Jurassic & & 12 \\
\hline 43. Levanto & Italy & Jurassic & & \\
\hline 44. Monte Maggiore & Corsica (France) & Jurassic & & $\sim 3600$ \\
\hline 45. Piemonte & Italy & Jurassic & & 1870-1920 metres thick \\
\hline 46. Rocchetta Vara & Italy & Jurassic & & \\
\hline 47. Scogna & Italy & Jurassic & & \\
\hline 48. Bou-Maïza Complex & Algeria & Jurassic & & \\
\hline 49. Komi Leibadi mélange & Greece & Jurassic & & \\
\hline 50. Koziakas & Greece & Mesozoic (Jurassic?) & & \\
\hline 51. Apuseni & Romania & Cretaceous-Jurassic & & 8000 \\
\hline 52. Masirah & Oman & Cretaceous & 140 & 450 \\
\hline 53. Ljubić & Serbia & Cretaceous & 136 & \\
\hline 54. Xigaze & China & Cretaceous & $124-127$ & \\
\hline 55. Band-e-Zeyarat/Dar Anar & Iran & Cretaceous-Jurassic & $121-146$ & \\
\hline 56. Kahnuj & Iran & Cretaceous-Jurassic & $121-146$ & $\sim 800$ \\
\hline 57. Dare Anar Complex (Kahnuj) & Iran & Cretaceous-Jurassic & $121-146$ & \\
\hline 58. Sapat-Jijal & Pakistan & Cretaceous & 118 & $\sim 180$ \\
\hline 59. Asa & China & Cretaceous & $114-118$ & \\
\hline 60. Birjand & Iran & Cretaceous & $107-113$ & \\
\hline 61. Semail (Oman) & Oman & Cretaceous & 96 & 11200 \\
\hline 62. Andaman & India & Cretaceous & 94 & \\
\hline 63. Mersin & Turkey & Cretaceous & 94 & 1500 \\
\hline 64. Pozant1-Karsant1 & Turkey & Cretaceous & 94 & 1300 \\
\hline 65. Kızıldağ & Turkey & Cretaceous & 92 & 1000 \\
\hline 66. Neyriz & Iran & Cretaceous & 92 & 602 \\
\hline 67. Limassol Forest Complex & Cyprus & Cretaceous & 92 & \\
\hline 68. Troodos & Cyprus & Cretaceous & 92 & \\
\hline 69. Burdur (Lycian) & Turkey & Cretaceous & 91 & \\
\hline 70. Köyceğiz (Lycian) & Turkey & Cretaceous & 91 & \\
\hline 71. Marmaris (Lycian) & Turkey & Cretaceous & 91 & \\
\hline 72. Yeşilova (Lycian) & Turkey & Cretaceous & 91 & \\
\hline 73. Mt. Medvednica & Croatia & Cretaceous-Jurassic & $85-150$ & \\
\hline 74. Haji Abad & Iran & Cretaceous & $85-95$ & 2000 \\
\hline 75. Chilas Complex & Pakistan & Cretaceous & 85 & 12000 \\
\hline
\end{tabular}




\begin{tabular}{|c|c|c|c|c|}
\hline 76. Mawat & Iraq & Cretaceous & $81-95$ & \\
\hline 77. Göksun (Kahramanmaraş) & Turkey & Cretaceous & $81-84$ & \\
\hline 78. Mount Ragola (External Ligurides) & Italy & Cretaceous & $\sim 72-86$ & $400-500$ metres thick \\
\hline 79. Mt. Prosara & Bosnia and Herzegovina & Cretaceous & 71 & \\
\hline 80. Nal & Pakistan & Cretaceous & 70 & $\sim 7$ \\
\hline 81. Kuluncak & Turkey & Cretaceous & $67-73$ & $\sim 50$ \\
\hline 82. Sabzevar & Iran & Cretaceous & $\sim 66-100$ & Up to 4500 \\
\hline 83. Khoy & Iran & Cretaceous & $65-101$ & \\
\hline 84. Muslim Bagh & Pakistan & Cretaceous-Jurassic & $65-87 ; 118-157$ & $\sim 330$ \\
\hline 85. Baft & Iran & Cretaceous & & \\
\hline 86. Fannuj & Iran & Cretaceous & & \\
\hline 87. Harsin & Iran & Cretaceous & & \\
\hline 88. Ispendere & Turkey & Cretaceous & & $\sim 40$ \\
\hline 89. Karadağ & Turkey & Cretaceous & & $\sim 105$ \\
\hline 90. Sahneh & Iran & Cretaceous & & \\
\hline 91. Shahr-Babak & Iran & Cretaceous & & \\
\hline 92. Southern Caspian Sea & Iran & Cretaceous & & 1800 \\
\hline 93. Berit & Turkey & Cretaceous & & \\
\hline 94. Sava Depression & Croatia & Paleocene-Cretaceous & $62-110$ & \\
\hline 95. Mt. Požeška Gora & Croatia & Paleocene-Cretaceous & $62-73$ & \\
\hline 86. Nehbandan & Iran & Paleocene-Cretaceous & $\sim 60-100$ & 250 \\
\hline 97. Naga Hills & India & Paleocene-Cretaceous & $\sim 56-72$ & $400-3000$ \\
\hline 98. Fanuj-Maskutan & Iran & Paleocene-Cretaceous & & \\
\hline 99. Waziristan & Pakistan & Paleocene & $55-66$ & $\sim 2000$ \\
\hline 100. Khost & Afghanistan & Paleocene & $55-66$ & \\
\hline
\end{tabular}




\begin{tabular}{ccccc}
\hline Anorthosite thickness & Grain size $(\mathrm{cm})$ & Plag. An (mol. \%) & Pyroxene Mg\# & Olivine Fo \\
\hline
\end{tabular}

Small dykes

Veins

Blocks

Metre- to decametre-scale olistoliths

Coarse

$\begin{array}{rr}50-90 & \\ 0.05-0.40 & 50-93\end{array}$

64-79 $72-92$

Layers/bands

Dykes

Layers

20 centimetre- to 4 metre-thick layers

Layers

0.1-1.0 metre-thick cyclic units

Layers

Up to 1 metre-thick layers

Centimetre- to decametre-thick layers up to 20 metres long

Layers

Layers

Lenses

$\sim 125$ metre-long by 20 metre-thick lense/phacoid
Fine to medium

$90-100$

Coarse

Fine to medium

50-89

80-85

50-90

$50-90$

2.0

$0.2-3.0$

86-90

$91-94$

90
$60-82$

65
$77-86$

50-90

44-78

69-83

Layers

1-10 centimetre-thick layers

Coarse
0.2-0.5
Medium

Small bodies

Up to hundreds of metres

Massive anorthosite dykes

Massive anorthosite dykes/Layers
$78-82$

79-89

92-96

86- 88

89-94

82-100

90-93

90-93

Calcic

Calcic

Calcic

Calcic

50-90

83-98
77-95 85

83-88

81-84

86-97

86-97

Dykes and sills

Up to 1 metre-thick layers 
Layers

Blocks

Lenses 1-2 metres in diameter

Thin layers

Layers

Dykes, sills, veins and layers

Layers

Rare bands

Bands

$\leq 2.0$

$\begin{array}{ll} & 70-90 \\ 0.20-0.60 & \text { Calcic } \\ & 50-90 \\ & 50-90 \\ \text { Medium } & 72-97\end{array}$

78-93

$82-83$

0.07-0.30 81-94

Medium to coarse $50-90$

Phaneritic

$70-100$

73-94

3.0-5.0 $86-88$

$77-98$

69-84

Layers 


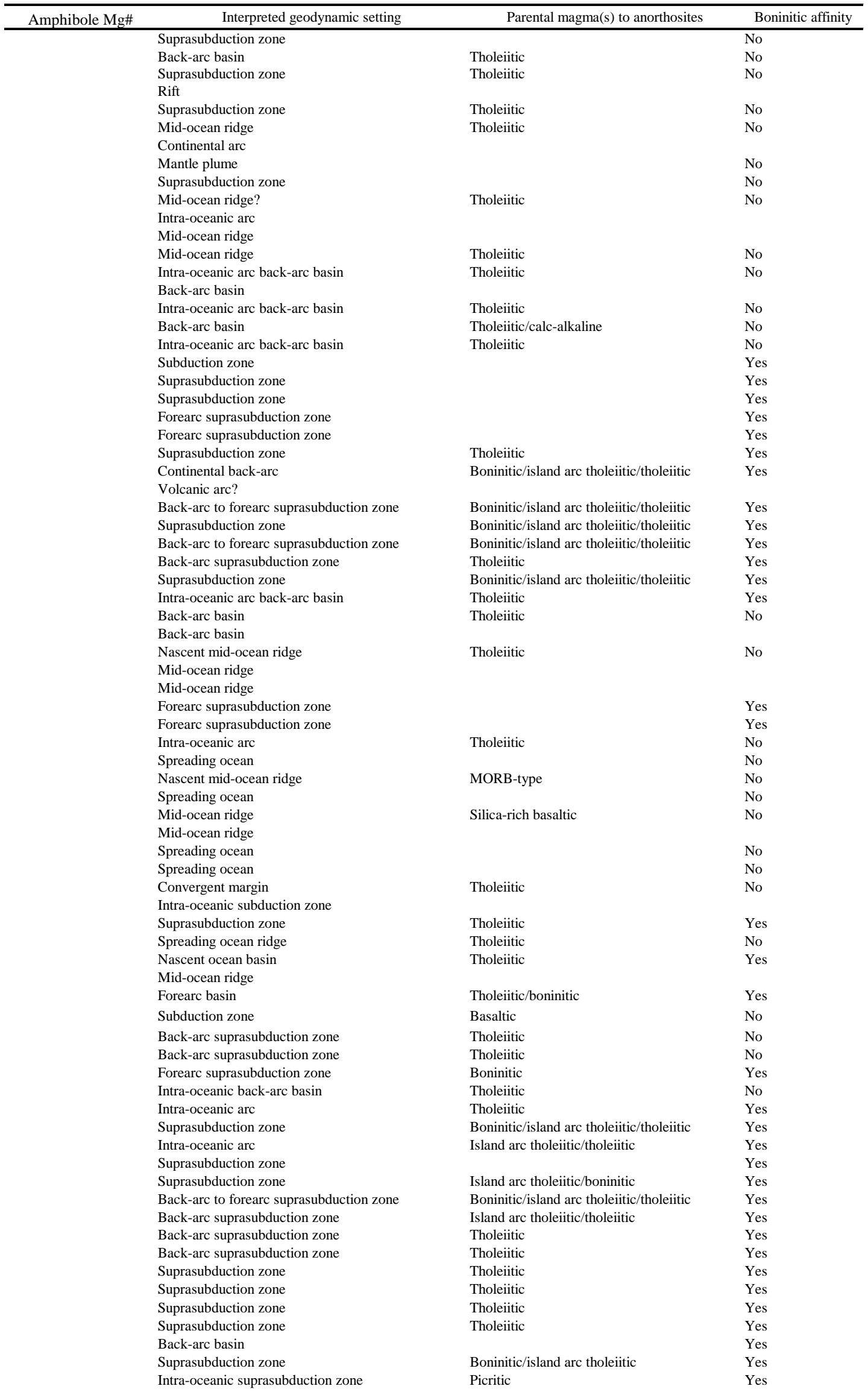


Subduction zone

Suprasubduction zone

Nascent ocean basin

Back-arc basin

Intra-oceanic subduction zone?

Intra-oceanic subduction zone

Intra-oceanic island arc

Back-arc suprasubduction zone

Suprasubduction zone

Island arc suprasubduction zone

Suprasubduction zone

Mid-ocean ridge/plume

Suprasubduction zone

Forearc suprasubduction zone

Mid-ocean ridge/plume

Intra-oceanic arc

Subduction zone

Suprasubduction zone

Back-arc basin

Back-arc basin

Back-arc suprasubduction zone

Subduction zone

Mid-ocean ridge

Back-arc suprasubduction zone

Back-arc suprasubduction zone
Tholeiitic $\quad$ Yes

Yes

No

Island arc tholeiitic

Tholeiitic Yes

Basaltic No

Island arc tholeiitic $\quad$ Yes

Tholeiitic No

No

Island arc tholeiitic Yes

Tholeiitic Yes

Island arc tholeiitic $\quad$ No

Tholeiitic Yes

Tholeiitic Yes

Tholeiitic T-MORB $\quad$ No 
Ophiolite geochemical affinity

$100 \%$ MORB

$66 \%$ Boninitic, 17\% IAT, $17 \%$ MORB

$66 \%$ Boninitic, 17\% IAT, 17\% MORB

$12 \%$ Boninitic, $60 \%$ IAT, $28 \%$ MORB

25\% IAT, $75 \%$ MORB

$66 \%$ Boninitic, 17\% IAT, 17\% MORB

MORB

$57 \%$ Boninitic, 14\% IAT, 29\% MORB

$50 \%$ IAT, 50\% MORB

3\% Boninitic, 90\% IAT, 7\% MORB

$33 \%$ IAT, $67 \%$ MORB 
$100 \%$ MORB

$15 \%$ IAT, $85 \%$ MORB

100\% MORB 
References

Savov et al. (2001), Zakariadze et al. (2012)

Zhu et al. (2016)

Zhai et al. (2013)

$\mathrm{Zi}$ et al. (2012)

Zhai et al. (2013)

Jian et al. (1999, 2008, 2009); Furnes et al. (2014)

Wang et al. (2014)

Jian et al. (2012)

Miao et al. (2008)

Peng and Zhu (1996), Zhu and Peng (1996), Zhang et al. (2003)

Scherreiks et al. (2014)

Yilmaz et al. (1982)

Costa and Caby (2001)

Wang et al. (2016)

Pamić et al. (2002)

Liu et al. (2016); Wang et al. (2016)

Rolland et al. (2010)

Wang et al. (2016)

Tang et al. (2018)

Hoeck et al. (2002); Šegvić et al. (2014)

Hoeck et al. (2002); Šegvić (2010); Šegvić et al. (2014)

Menzies (1973); Mitsis and Economou-Eliopoulos (2001); Kapsiotis et al. (2019)

Mitsis and Economou-Eliopoulos (2001); Kapsiotis et al. (2019)

Bonev and Stampfli (2009)

Alparslan and Dilek (2018)

Lu et al. (1994)

Bortolotti et al. (2004); Beccaluva et al. (2005); Furnes et al. (2014)

Pe-Piper et al. (2004); Furnes et al. (2014)

Bortolotti et al. (2004); Furnes et al. (2014); Saccani and Tassinari (2015)

Galoyan et al. (2009); Rolland et al. (2010); Furnes et al. (2014)

Economou-Eliopoulos et al. (2008); Furnes et al. (2014)

Wang et al. (2016)

Galoyan et al. (2007); Rolland et al. (2010)

Pamić et al. (2002)

Saccani et al. (2000)

De Graciansky et al. (2011); Furnes et al. (2014)

Pamić et al. (2002); Bazylev et al. (2003)

Hoeck et al. (2002); Chiari et al. (2011)

Hoeck et al. (2002); Chiari et al. (2011)

Azizi et al. (2015)

Renna et al. (2016)

Cabella et al. (2002); Baumgartner et al. (2013)

Renna et al. (2016)

Piccardo and Guarnieri (2011)

Vogler (1987)

Renna et al. (2016)

Renna et al. (2016)

Mechati et al. (2018)

Scherreiks (2000)

Bortolotti et al. (2004)

Herz and Savu (1974)

Abbotts (1979); Furnes et al. (2014)

Pamić et al. (2002)

Dai et al. (2013)

Ghazi et al. (2004)

Arvin et al. (2001, 2005); Moghadam and Stern (2015)

Arvin et al. (2001, 2005); Moghadam and Stern (2015)

Jan et al. (1993); Ringuette (1996); Hébert et al. (2012)

Zeng et al. (2018)

Zarrinkoub et al. (2012)

Ashwal (1993); Yamasaki et al. (2006); Rollinson (2008); Boudier and Nicolas (2011a, b); Furnes et al. (2014); Goodenough et al. (2010, 2014)

Furnes et al. (2014); Rao et al. (2016)

Parlak et al. (1996); Çelik (2008); Morris et al. (2017); Nurlu et al. (2018)

Parlak et al. (1996); Çelik (2008); Saka et al. (2014)

Bağci et al. (2005); Dilek and Thy (2009); Furnes et al. (2014)

Sakkarinejad (2003); Fazlnia et al. (2009); Rajabzadeh et al. (2013); Furnes et al. (2014); Moghadam et al. (2014); Attarzadeh et al. (2017)

Taylor and Nesbitt (1988); Ashwal (1993); Zirner et al. (2013); Furnes et al. (2014); Golowin et al. (2017)

Thayer (1980); Taylor and Nesbitt (1988); Ashwal (1993); Sotiriou (2012); Zirner et al. (2013); Furnes et al. (2014); Golowin et al. (2017)

Çelik and Delaloye (2003); Çelik and Chiaradia (2008)

Çelik and Delaloye (2003); Çelik and Chiaradia (2008)

Çelik and Delaloye (2003); Çelik and Chiaradia (2008)

Çelik and Delaloye (2003); Çelik and Chiaradia (2008)

Pamić et al. (2002); Slovenec and Šegvić (2019)

Moghadam and Stern (2015)

Khan et al. (1989); Jan et al. (1993); Jagoutz et al. (2006, 2007); Takahashi et al. (2007); Hébert et al. (2012); Petterson (2018) 
Abdulzahra (2008); Mohammad et al. (2016); Al Humadi et al. (2019)

Bağc1 (2013); Parlak et al. (2019)

Marroni and Tribuzio (1996)

Pamić et al. (2002)

Khan et al. (2018)

Elitok et al. (2014); Camuzcuoğlu et al. (2017)

Furnes et al. (2014); Rahmani et al. (2017)

Hassanipak and Ghazi (2000); Khalatbari-Jafari et al. (2003, 2006); Furnes et al. (2014)

Furnes et al. (2014); Kakar et al. (2014)

Golestani (2013)

Jafari et al. (2017)

Jafari et al. (2017)

Parlak et al. (2013b)

Parlak et al. (2013a); Robertson et al. (2013)

Jafari et al. (2017)

Ghazi and Hassanipak (2000)

Salavati et al. (2013)

Awalt and Whiltney (2018); Yilmaz (2018)

Pamić et al. (2002)

Pamić et al. (2002)

Saccani et al. (2010); Furnes et al. (2014)

Ghose and Agrawal (2010); Ghose (2011)

Desmons and Beccaluva (1983)

Arif and Jan (2006); Ghose and Chatterjee (2014); Furnes et al. (2014)

Arif and Jan (2006); Ghose and Chatterjee (2014); Furnes et al. (2014) 
Table S2. Archean anorthosite-bearing layered intrusion occurrences.

\begin{tabular}{|c|c|c|}
\hline Occurrence & Location & Age \\
\hline 1. Nulliak Supracrustal Assemblage & Labrador, Canada & Eoarchean \\
\hline 2. Tula Mountains, Napier Metamorphic Complex (2 localities) & Antarctica & Eoarchean \\
\hline 3. Itsaq Gneiss Complex & Greenland & Eoarchean \\
\hline 4. Nuvvuagittuq (Porpoise Cove) greenstone belt & Québec, Canada & Eoarchean \\
\hline 5. Ujaragssuit layered xenolith & Greenland & Eoarchean \\
\hline 6. Manfred Complex & Western Australia, Australia & Eoarchean \\
\hline 7. Acasta Gneiss Complex & Northwest Territories, Canada & Paleoarchean-Eoarchean \\
\hline 8. Mount Webber Gabbro & Western Australia, Australia & Paleoarchean \\
\hline 9. Mponono Intrusive Suite & Eswatini (Swaziland) & Paleoarchean \\
\hline 10. Onverwacht Sills & South Africa & Paleoarchean \\
\hline 11. Messina Complex & South Africa & Paleoarchean \\
\hline 12. Mentzel Plutonic Association (Saglek Area) & Labrador, Canada & Paleoarchean \\
\hline 13. Holenarasipir Complex (Dodkadnur) & India & Paleoarchean \\
\hline 14. Holenarasipir Complex (Honnavalli) & India & Paleoarchean \\
\hline 15. Hopedale Block & Labrador, Canada & Paleoarchean \\
\hline 16. Lagoa da Vaca Complex & Brazil & Mesoarchean \\
\hline 17. Bangur Gabbro Complex & India & Mesoarchean \\
\hline 18. Nuasahi massif (Iron Ore Group) & India & Mesoarchean \\
\hline 19. Kurihundi Intrusion & India & Mesoarchean \\
\hline 20. Nuggihalli Complex & India & Mesoarchean \\
\hline 21. Kuliana Gabbro-Anorthosite Suite & India & Mesoarchean \\
\hline 22. Badampahar Gabbro-Anorthosite Intrusion & India & Mesoarchean \\
\hline 23. Ivisaartoq greenstone belt & Greenland & Mesoarchean \\
\hline 24. Ujarassuit greenstone belt & Greenland & Mesoarchean \\
\hline 25. Stella Layered Intrusion & South Africa & Mesoarchean \\
\hline 26. Senador Elói de Souza Complex & Brazil & Mesoarchean \\
\hline 27. Andover Intrusion & Western Australia, Australia & Mesoarchean \\
\hline 28. Tessiuyakh Gabbro Complex (Nain-Okhakh Area) & Labrador, Canada & Mesoarchean \\
\hline 29. Ness & Scotland, U.K. & Mesoarchean \\
\hline 30. Sindhuvalli & India & Mesoarchean \\
\hline 31. South Harris Complex & Scotland, U.K. & Mesoarchean \\
\hline 32. Isle of Lewis and Harris ( 2 occurrences) & Scotland, U.K. & Mesoarchean \\
\hline 33. Younger Suite (Saglek Area) & Labrador, Canada & Mesoarchean \\
\hline 34. Loch Laxford & Scotland, U.K. & Mesoarchean \\
\hline 35. Achiltibuie & Scotland, U.K. & Mesoarchean \\
\hline 36. Drumbeg & Scotland, U.K. & Mesoarchean \\
\hline 37. Naajat Kuuat Complex & Greenland & Mesoarchean \\
\hline 38. Fiskenæsset Complex & Greenland & Mesoarchean \\
\hline 39. Novengilla Suite, Rooiwater Complex & South Africa & Mesoarchean \\
\hline 40. Millindinna Intrusion & Western Australia, Australia & Mesoarchean \\
\hline 41. Munni Munni Intrusion & Western Australia, Australia & Mesoarchean \\
\hline 42. Severnyi Massif & Russia & Mesoarchean \\
\hline 43. Nunataarsuk Complex & Greenland & Mesoarchean \\
\hline 44. Amsaga (6 occurrences) & Mauritania & Mesoarchean \\
\hline 45. Guelb el Azib Layered Complex & Mauritania & Mesoarchean \\
\hline 46. Bhavani Complex & India & Mesoarchean \\
\hline 47. Gebel El Asr Complex & Egypt & Mesoarchean \\
\hline 48. Dåvøya, West Troms Basement Complex & Norway & Mesoarchean \\
\hline 49. Helgøya, West Troms Basement Complex & Norway & Mesoarchean \\
\hline 50. Hersøya, West Troms Basement Complex & Norway & Mesoarchean \\
\hline 51. Kristoffervalen, West Troms Basement Complex & Norway & Mesoarchean \\
\hline 52. Lille Måsværet, West Troms Basement Complex & Norway & Mesoarchean \\
\hline 53. Nordkvaløya-Rebbenes $\varnothing y a$, West Troms Basement Complex & Norway & Mesoarchean \\
\hline 54. Ringvassøya, West Troms Basement Complex (2 occurrences) & Norway & Mesoarchean \\
\hline 55. Stor Skorøya, West Troms Basement Complex & Norway & Mesoarchean \\
\hline 56. Store Måsværet, West Troms Basement Complex & Norway & Mesoarchean \\
\hline 57. Vanna, West Troms Basement Complex (2 occurrences) & Norway & Mesoarchean \\
\hline 58. Rio Jararé Sill & Brazil & Mesoarchean \\
\hline 59. Andammen, West Troms Basement Complex & Norway & Mesoarchean \\
\hline 60. Gråtind Migmatite, West Troms Basement Complex (3 occurrences) & Norway & Mesoarchean \\
\hline 61. Grøtøya, West Troms Basement Complex & Norway & Mesoarchean \\
\hline 62. Kvaløya, West Troms Basement Complex (2 occurrences) & Norway & Mesoarchean \\
\hline 63. Rebbenesøya, West Troms Basement Complex ( 3 occurrences) & Norway & Mesoarchean \\
\hline 64. Ringvassøya, West Troms Basement Complex (2 occurrences) & Norway & Mesoarchean \\
\hline 65. Sandøya, West Troms Basement Complex & Norway & Mesoarchean \\
\hline 66. Vengsøya, West Troms Basement Complex & Norway & Mesoarchean \\
\hline 67. Fishtrap Lake Intrusion & Ontario, Canada & Mesoarchean \\
\hline 68. Highbank Lake Intrusion & Ontario, Canada & Mesoarchean \\
\hline 69. Windimurra Intrusion & Western Australia, Australia & Mesoarchean \\
\hline 70. Stor $\varnothing$ greenstone belt & Greenland & Mesoarchean \\
\hline 71. Nachvak Fjord & Labrador, Canada & Mesoarchean \\
\hline 72. Northern Labrador & Labrador, Canada & Mesoarchean \\
\hline 73. Arveprinsen Ejland & Greenland & Mesoarchean \\
\hline 74. Innarsuaq & Greenland & Mesoarchean \\
\hline 75. Rensdyrnunatak & Greenland & Mesoarchean \\
\hline 76. Boye S $\varnothing$ Anorthosite Complex & Greenland & Mesoarchean \\
\hline
\end{tabular}


77. Dingo Intrusion

78. Maitland Intrusion

79. Mount Sholl Intrusion

80. Sherlock Intrusion

81. Modipe Gabbro Complex

82. Gaborone Granite Suite

83. Shawmere Anorthosite Complex

84. Pipestone Lake Anorthosite Complex

85. Kolmozero Complex

86. Bird River Sill ( 8 intrusive bodies)

87. Cat Lake Intrusion

88. Coppermine Bay Intrusion

89. Euclid Lake Intrusion

90. New Manitoba Mine Intrusion

91. Mayville Intrusion

92. Gebel Kamil Complex

93. Big Mac Intrusion

94. Black Thor Intrusive Complex

95. Thunderbird Intrusion

96. Butler East Intrusion

97. Butler West Intrusion

98. Ring of Fire Intrusive Suite (5 intrusions)

99. Croal Lake Intrusion

100. Doré Lake Complex

101. Wabassi Main Intrusion

102. Haines Gabbroic Complex

103. Bad Vermilion Lake Anorthosite Complex

104. Stillwater Complex

105. Dåfjord Gneiss, West Troms Basement Complex

106. Bantoro Leucogabbro

107. Bear Head Lake Complex

108. Bell River Complex

109. Cauchon Lake Anorthosite Complex

110. Fredrikshåb Area

111. Godthåb-Ameralik Area

112. Hairy-Butterfly Lakes Complex

113. Ivigtut Area

114. Kasila Group

115. Minago River Complex

116. Sample Creek

117. Split Lake Anorthosite Complex

118. Tingmiarmiut Area

119. Ferguson Lake Igneous Complex

120. Laughland Lake Intrusion

121. Angmagssalik Area

122. Skjoldungen Alkaline Igneous Province (14 individual unnamed intrusions)

123. Stærkodder Intrusion

124. Uivak Intrusion

125. Vend Om Intrusion

126. Achinsk Complex

127. Patchemvarek Massif

128. Tsaga Massif

129. Medveh'e-Shchuch'eoerskii Massif

130. Yellowknife greenstone belt

131. Ikongwe Massif

132. Axis Lake Intrusion

133. Kalarsky Complex

134. Masanikere Intrusion

135. Konkanhundi Gabbro-Anorthosite Suite

136. São José do Jacuipe Gabbro-Anorthosite Stratiform Complex

137. Curaçá Valley (18 intrusions)

138. Nurlaty Massif

139. Tuimazy Massif

140. Love Lake Leucogabbro

141. Agali Hill Ophiolite

142. Sittampundi Anorthosite Complex

143. Devanur Ophiolite

144. Main Range Massif

145. Big Trout Lake Complex

146. Tongyu Anorthosite Complex

147. Upernavik

148. Aniyapuram Mafic-Ultramafic Complex

149. Attappadi

150. Jequié Complex

151. Nilgiri Block

152. Yishui Ophiolite

153. Monchegorsk Intrusion

154. Queen Maud Block

155. Santa Maria do Chico Complex
Western Australia, Australia

Western Australia, Australia

Western Australia, Australia

Western Australia, Australia

Botswana/South Africa

Botswana/South Africa

Ontario, Canada

Manitoba, Canada

Russia

Manitoba, Canada

Manitoba, Canada

Manitoba, Canada

Manitoba, Canada

Manitoba, Canada

Manitoba, Canada

Egypt

Ontario, Canada

Ontario, Canada

Ontario, Canada

Ontario, Canada

Ontario, Canada

Ontario, Canada

Ontario, Canada

Québec, Canada

Ontario, Canada

Ontario, Canada

Ontario, Canada

Montana, U.S.A.

Norway

Sierra Leone

Manitoba, Canada

Québec, Canada

Manitoba, Canada

Greenland

Greenland

Manitoba, Canada

Greenland

Sierra Leone

Manitoba, Canada

Liberia

Manitoba, Canada

Greenland

Northwest Territories, Canada

Nunavut, Canada

Greenland

Greenland

Greenland

Greenland

Greenland

Russia

Russia

Russia

Russia

Northwest Territories, Canada

Tanzania

Saskatchewan, Canada

Russia

India

India

Brazil

Brazil

Russia

Russia

Saskatchewan, Canada

India

India

India

Russia

Ontario, Canada

China

Greenland

India

India

Brazil

India

China

Russia

Northwest Territories, Canada

Brazil
Mesoarchean

Mesoarchean

Mesoarchean

Mesoarchean

Neoarchean

Neoarchean

Neoarchean

Neoarchean

Neoarchean

Neoarchean

Neoarchean

Neoarchean

Neoarchean

Neoarchean

Neoarchean

Neoarchean

Neoarchean

Neoarchean

Neoarchean

Neoarchean

Neoarchean

Neoarchean

Neoarchean

Neoarchean

Neoarchean

Neoarchean

Neoarchean

Neoarchean

Neoarchean-Mesoarchean

Neoarchean

Neoarchean

Neoarchean

Neoarchean

Neoarchean

Neoarchean

Neoarchean

Neoarchean

Neoarchean

Neoarchean

Neoarchean

Neoarchean

Neoarchean

Neoarchean

Neoarchean

Neoarchean

Neoarchean

Neoarchean

Neoarchean

Neoarchean

Neoarchean

Neoarchean

Neoarchean

Neoarchean

Neoarchean

Neoarchean

Neoarchean

Neoarchean

Neoarchean

Neoarchean

Neoarchean

Neoarchean

Neoarchean

Neoarchean

Neoarchean

Neoarchean

Neoarchean

Neoarchean

Neoarchean

Neoarchean

Neoarchean

Neoarchean

Neoarchean

Neoarchean

Neoarchean

Neoarchean

Paleoproterozoic-Neoarchean

Paleoproterozoic-Neoarchean

Paleoproterozoic-Neoarchean

Paleoproterozoic-Neoarchean 


\begin{tabular}{|c|c|c|c|c|c|}
\hline Age (Ma) & Size $\left(\mathrm{km}^{2}\right)$ & Anorthosite thickness & Grain size $(\mathrm{cm})$ & Megacrystic? & Plag. An (mol.\%) \\
\hline \multicolumn{6}{|l|}{$>3950$} \\
\hline$>3927$ & $<1$ & Layers & & & $50-70$ \\
\hline$>3850$ & $\sim 3000$ & Centimetre-thick layers & & & \\
\hline 3825 & & Layers & & & \\
\hline 3810 & 80 & Up to 20 centimetre-thick layers & & & $22-76$ \\
\hline 3730 & $<10$ & & $2.0-30.0$ & Yes & $75-95$ \\
\hline $3590-4000$ & & Layers & Up to 1 centimetre & Yes & \\
\hline $3580-3590$ & 0.04 & & $\leq 0.6$ & & \\
\hline$\sim 3450$ & $>10$ & & $\leq 10.0$ & Yes & \\
\hline 3450 & $>10$ & & & & $92-94$ \\
\hline 3344 & $>100$ & & $\leq 10.0$ & Yes & $70-85$ \\
\hline$>3318$ & $<10$ & & & & \\
\hline$\sim 3290$ & $<10$ & 300 metres & Fine-grained & & 92-95 \\
\hline 3285 & $<10$ & 50 metres & Fine-grained & & $92-95$ \\
\hline$>3200$ & $<10$ & & & & \\
\hline 3161 & 32 & & & Yes & $53-67$ \\
\hline \multicolumn{6}{|l|}{3122} \\
\hline $3119-3123$ & $\sim 10$ & Layers & & & \\
\hline$>3100$ & $<10$ & & & & $63-74$ \\
\hline 3100 & $<10$ & & & & 88 \\
\hline $3090-3120$ & 1 & Layers & $\leq 0.4$ & & $76-85$ \\
\hline$>3090$ & $\sim 30$ & & & & \\
\hline 3075 & $\sim 700$ & Metres to kilometres & & & \\
\hline \multicolumn{6}{|c|}{ (1) } \\
\hline 3033.5 & 12 & & & & \\
\hline 3033 & $\sim 50$ & & & & $92-97$ \\
\hline 3016 & 140 & & & & \\
\hline$>3000$ & $<10$ & & $\leq 10.0$ & Yes & $63-88$ \\
\hline$>3000$ & & & & & Andesine \\
\hline$>3000$ & $<10$ & & & & $89-94$ \\
\hline$>3000$ & 46 & & & & $61-84$ \\
\hline \multicolumn{6}{|l|}{$>3000$} \\
\hline$>3000$ & $<10$ & & & & \\
\hline$<3000$ & 4.8 & & $\leq 3.0$ & Yes & \\
\hline \multicolumn{6}{|l|}{$<3000$} \\
\hline \multicolumn{6}{|l|}{$<3000$} \\
\hline 2985 & & & $\leq 3.0$ & Yes & 80 \\
\hline 2973 & $\sim 500$ & Up to 150 metres & $\leq 40.0$ & Yes & $75-98$ \\
\hline \multicolumn{6}{|l|}{$\sim 2970$} \\
\hline $2950-2970$ & 150 & & & & \\
\hline 2925 & 135 & & & & \\
\hline 2920 & & & & & $45-65$ \\
\hline 2914 & $\sim 35$ & & $2.0-5.0$ & Yes & $77-89$ \\
\hline \multicolumn{6}{|l|}{$>2900$} \\
\hline$>2900$ & $\leq 15$ & & $\leq 0.3$ & & \\
\hline 2898 & $\sim 30$ & $0.5-5$ metres & & & \\
\hline 2845 & 200 & & & & $70-81$ \\
\hline$\sim 2842$ & $\sim 4$ & & & & \\
\hline$\sim 2842$ & $\sim 50$ & & & & \\
\hline$\sim 2842$ & $\sim 10$ & & & & \\
\hline$\sim 2842$ & $\sim 2$ & & & & \\
\hline$\sim 2842$ & $\sim 2$ & & & & \\
\hline$\sim 2842$ & $\sim 65$ & & & & \\
\hline$\sim 2842$ & $\sim 350$ (in total) & & & & \\
\hline$\sim 2842$ & $\sim 10$ & & & & \\
\hline$\sim 2842$ & $\sim 4.5$ & & & & \\
\hline$\sim 2842$ & $\sim 550$ (in total) & & & & \\
\hline 2841 & $\sim 84$ & & Megacrystic & Yes & \\
\hline$>2835$ & $\sim 12$ & & & & \\
\hline$>2835$ & $\sim 100$ (in total) & & & & \\
\hline$>2835$ & $\sim 12$ & & & & \\
\hline$>2835$ & $\sim 550$ (in total) & & & & \\
\hline$>2835$ & $\sim 130$ (in total) & & & & \\
\hline$>2835$ & $\sim 170$ (in total) & & & & \\
\hline$>2835$ & $\sim 8$ & & & & \\
\hline$>2835$ & $\sim 20$ & & & & \\
\hline$\sim 2810$ & 270 & Layers & Medium to coarse & & $31-71$ \\
\hline$\sim 2810$ & 420 & Layers & Medium to coarse & & $24-99$ \\
\hline$\sim 2810$ & 2200 & Layers & & & $\sim 75$ \\
\hline $2800-3060$ & $\sim 25$ & & & & \\
\hline$>2800$ & $<10$ & & & & \\
\hline$>2800$ & $<10$ & & & & \\
\hline$\sim 2800$ & & Layers & & & \\
\hline$\sim 2800$ & & Layers & & & \\
\hline$\sim 2800$ & & Layers & & & \\
\hline$\sim 2800$ & $\sim 25$ & Layers & $\leq 10.0$ & Yes & \\
\hline
\end{tabular}


2 kilometres thick

18

$>2785$

2782-2785

$2758 \sim 10$

$2750 \sim 20$

$2743 \sim \sim 15$

$\sim 2743$ ? $\quad \sim 0.30$

$2743 \sim \sim 0.80$

$2743 \sim 0.30$

$2743 \sim 0.40$

$2742.8 \sim 15$

$2741 \quad 400$

$2734 \quad 120$

$2734 \sim 6$

$2734 \sim 75$

2733-2734 30

2733-2734 $\sim 100$

2733-2734 140 (combined)

2733 $\sim 2728$

2727

2722

2716

2701

2700-2850

$>2700$

$>2700$

$>2700$

$>2700$

$>2700$

$>2700$

$>2700$

$>2700$

$>2700$

$>2700$

$>2700$

$>2700$

$>2700$

$\sim 2700$

$\sim 2700$

2698

2698

2698

2698

2698

2678

2662

2660-2670

2660

2658-2722

2643

2630

2623

$\sim 2600$

2594-2627

2583.7

2580

2570

2570

$\sim 2562$

2547

2541

2528-2545

2501-2505

$>2500$

$>2500$

$>2500$

250

42

27

100

$\sim 4400$

100 metre-thick sheet

$<10$

550

$\sim 20$

$<10$

$\sim 500$

$\sim 25$

$<10$

$>10$

25

30

$<10$

$\sim 50$

$<10$

120

$\sim 2000$

95

$<20$

1000

$<10$

35

1000

1800

$>40$

$<1$

$>30$

$\sim 24$

440

$\sim 300$

$>15$
$<10$

2495-2538

2493-2507

2460-2500

2124-2550

\begin{tabular}{|c|c|c|c|}
\hline & $\leq 45.0$ & Yes & $65-95$ \\
\hline \multirow[t]{2}{*}{ Up to 150 metres } & $2.0-25.0$ & Yes & $75-80$ \\
\hline & $\leq 4.0$ & Yes & $64-85$ \\
\hline \multirow[t]{3}{*}{ Up to 90 metres } & $\leq 3.0$ & Yes & $70-85$ \\
\hline & $\leq 2.0$ & Yes & $76-94$ \\
\hline & $\leq 3.0$ & Yes & \\
\hline \multirow[t]{2}{*}{350 metres } & $\leq 3.0$ & Yes & $63-99$ \\
\hline & & & $46-54$ \\
\hline Layers up to 4 centimetres thick & Medium to coarse & & $20-90$ \\
\hline Layers & Medium to megacrystic & Yes & $78-87$ \\
\hline Layers & Medium & & $37-86$ \\
\hline Layers & Medium & & $37-86$ \\
\hline \multirow[t]{6}{*}{ Layers } & Medium & & $37-86$ \\
\hline & $\leq 5.0$ & Yes & $60-80$ \\
\hline & Fine to coarse & & $31-96$ \\
\hline & $\leq 2.0$ & Yes & \\
\hline & $1.0-20.0$ & Yes & $75-81$ \\
\hline & & & $73-79$ \\
\hline \multirow[t]{10}{*}{ Layers } & $\leq 10.0$ & Yes & $50-84$ \\
\hline & & & $64-84$ \\
\hline & & & $60-80$ \\
\hline & $\leq 15.0$ & Yes & $64-84$ \\
\hline & & & $35-81$ \\
\hline & & & $60-82$ \\
\hline & & & $64-84$ \\
\hline & & & $35-75$ \\
\hline & & & $50-85$ \\
\hline & & & $64-84$ \\
\hline \multicolumn{4}{|l|}{$1-5$ centimetre-thick layers } \\
\hline & & & $85-95$ \\
\hline & & & $>70$ \\
\hline & $\leq 3.5$ & Yes & \\
\hline & $\leq 6.0$ & Yes & $70-85$ \\
\hline
\end{tabular}

Layers

Layers

Layers

Layers

0.5-2.0 centimetres

Yes

56-94

65-85

$70-85$

Layers Megacrystic

Yes

$60-70$

$10 \rightarrow 70$

$\sim 60$

$50-90$

Coarse

$\leq 5.0$

Yes

31-70

40-58

46-65

Medium

$\leq 1.0$

Yes

60

80-100

50-70

$\leq 10.0$

Yes

51-7

$\sim 70$ 


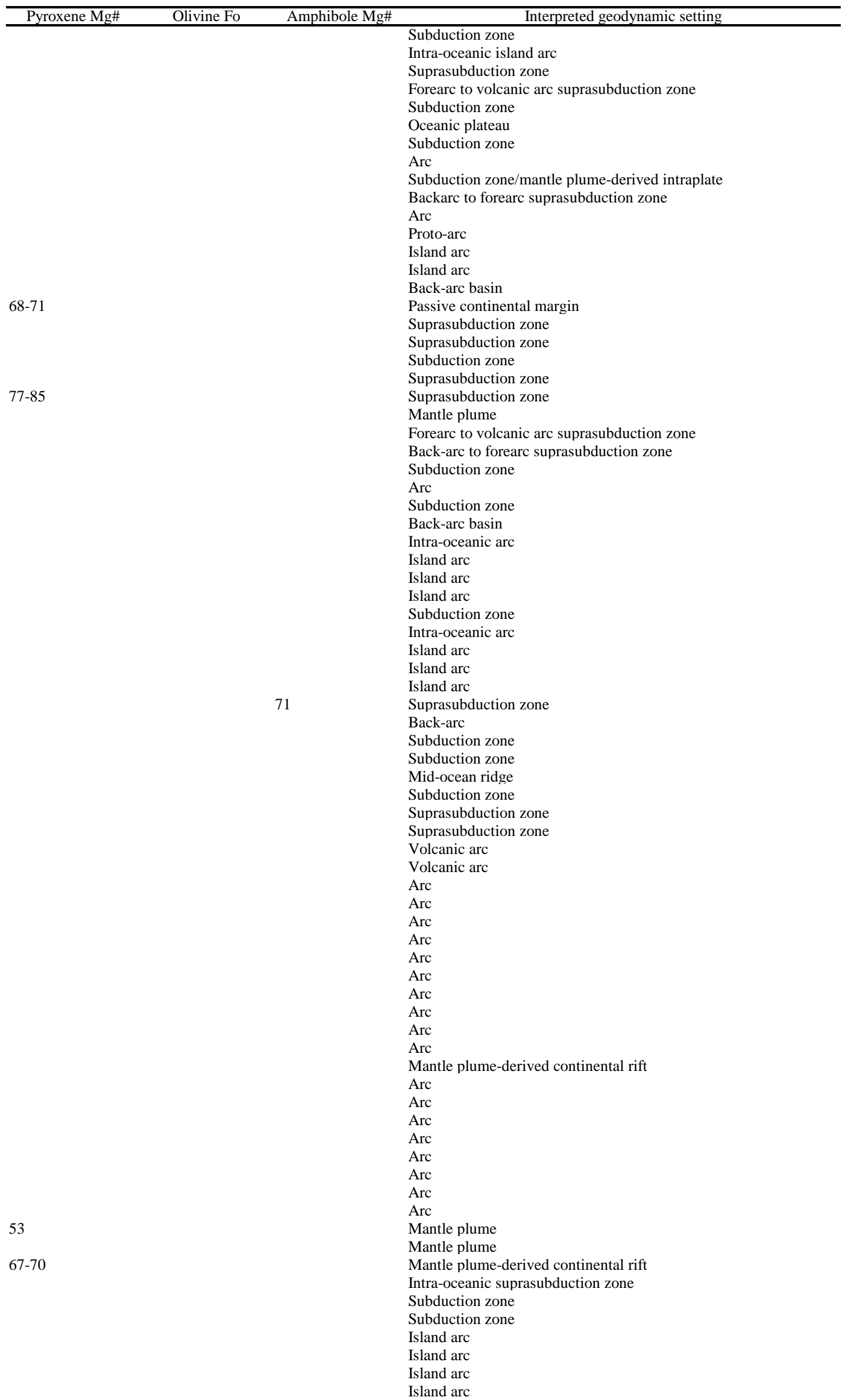


Subduction zone

Subduction zone

Subduction zone

Subduction zone

Subduction zone

Synorogenic

Arc

Back-arc

Quasi-platform

71-82

Chilean-style continental back-arc

Back-arc

Convergent margin

Back-arc

Back-arc

51-82 Chilean-style continental back-arc

Volcanic arc

Mantle plume

Mantle plume

Mantle plume

Mantle plume

Mantle plume

Mantle plume

Mantle plume

Back-arc suprasubduction zone

Arc

Japan-style mature intra-oceanic continental back-arc

Intra-oceanic arc

Subduction zone

Arc

Subduction zone

Arc

Back-arc basin

Arc

Arc

Arc

Arc

Arc

Subduction zone

Arc

Subduction zone

Arc

Subduction zone

Back-arc basin

Continental rift

Subduction zone

Subduction zone

Subduction zone

Subduction zone

Subduction zone

Anorogenic

Quasi-platform

Anorogenic

Anorogenic

Volcanic arc suprasubduction zone and plume

Post-orogenic

Oceanic arc

Post-orogenic/back-arc

Active continental margin

Continental arc

Continental arc

Arc

Post-orogenic

Post-orogenic

Subduction zone

Suprasubduction zone

Suprasubduction zone

Suprasubduction zone

Synkinematic

Intracratonic rift

Island arc

Arc

Suprasubduction zone

Arc

Island arc

Arc

Suprasubduction zone

Synkinematic

Incipient continental rift

Arc 


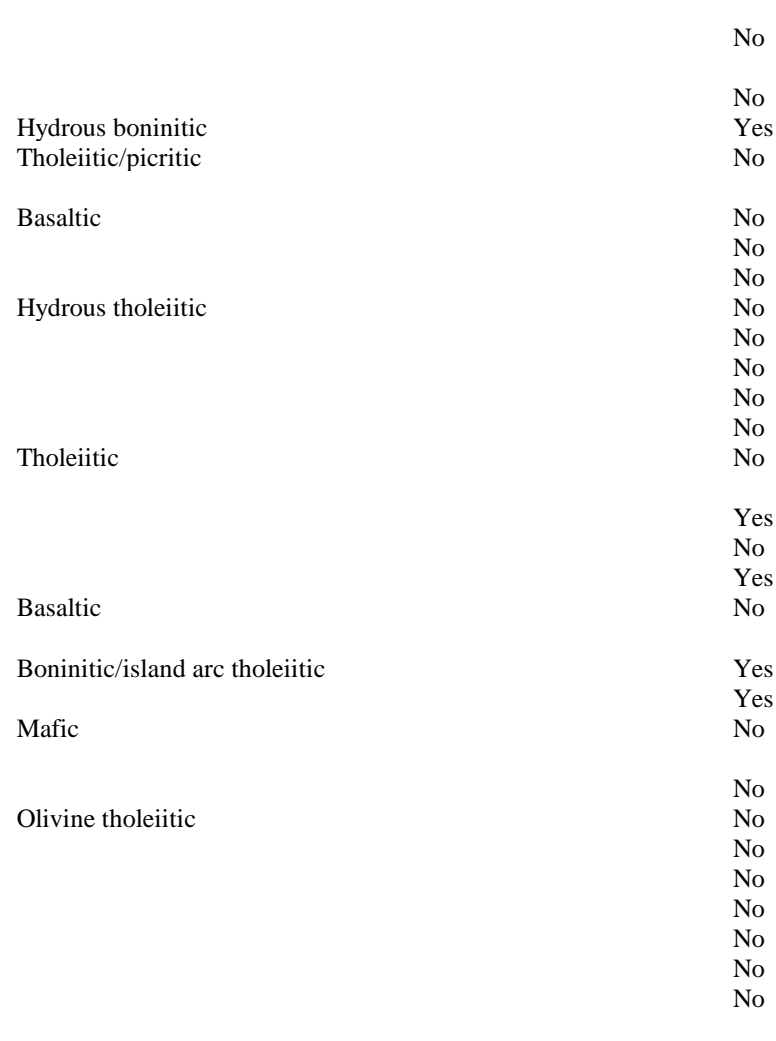

Hydrous high $\mathrm{Al}$ basaltic

Hydrous tholeiitic

Hydrous high Al tholeiitic?

No

Hydrous high Al tholeiitic

Tholeiitic

No

No 


\begin{tabular}{|c|c|}
\hline & $\begin{array}{l}\text { No } \\
\text { No } \\
\text { No } \\
\text { No }\end{array}$ \\
\hline Mantle-derived & No \\
\hline Aluminous tholeiitic & No \\
\hline \multirow[t]{2}{*}{ Tholeiitic } & No \\
\hline & No \\
\hline Hydrous primitive arc tholeiitic/Ca- and Al-rich tholeiitic & No \\
\hline Tholeiitic? & No \\
\hline Tholeiitic? & No \\
\hline Tholeitic & No \\
\hline Tholeiitic? & No \\
\hline Hydrous primitive arc tholeiitic/Ca- and Al-rich tholeiitic & No \\
\hline High Fe and Ti basaltic & No \\
\hline Komatiitic basaltic & No \\
\hline Mafic & No \\
\hline Mafic & No \\
\hline \multirow[t]{2}{*}{ Mafic } & No \\
\hline & No \\
\hline Basaltic & No \\
\hline \multirow[t]{2}{*}{ Hydrous Ca- and Al-rich tholeiitic/boninitic } & Yes \\
\hline & No \\
\hline Boninitic & Yes \\
\hline Basic to intermediate & No \\
\hline Tholeiitic & No \\
\hline \multirow[t]{3}{*}{ Tholeiitic } & No \\
\hline & No \\
\hline & No \\
\hline \multirow[t]{2}{*}{ Tholeiitic } & No \\
\hline & No \\
\hline Basic to intermediate & No \\
\hline Tholeiitic & No \\
\hline \multirow[t]{2}{*}{ Tholeiitic } & No \\
\hline & No \\
\hline \multirow[t]{3}{*}{ Basaltic } & No \\
\hline & No \\
\hline & No \\
\hline Mafic & No \\
\hline Mafic & No \\
\hline Mafic & No \\
\hline \multirow[t]{2}{*}{ Mafic } & No \\
\hline & No \\
\hline \multirow[t]{2}{*}{ Basaltic } & No \\
\hline & No \\
\hline High Al basaltic & No \\
\hline \multirow[t]{2}{*}{ Hydrous tholeiitic } & No \\
\hline & No \\
\hline \multirow[t]{2}{*}{ Hydrous aluminous tholeiitic } & Yes? \\
\hline & No \\
\hline \multirow[t]{2}{*}{ Silicic high Mg (boninitic) } & Yes \\
\hline & No \\
\hline Primitive tholeiitic & No \\
\hline \multirow{3}{*}{$\begin{array}{l}\text { Tholeiitic } \\
\text { Silicic high Mg (boninitic) }\end{array}$} & No \\
\hline & Yes \\
\hline & No \\
\hline
\end{tabular}


Reference

Ryan and Martineau (2012); Komiya et al. (2015)

Sheraton et al. (1980); Ashwal (1993); Ishizuka (2008)

Nutman et al. (2009)

O'Neil et al. (2007); Furnes et al. (2015)

Rollinson et al. (2002)

Myers (1988); Rowe and Kemp (2019)

Iizuka et al. (2007); Koshida et al. (2016); Reimink et al. (2016)

Petersson et al. (2019)

Hunter et al. (1978); Tankard et al. (1982); Jackson (1984); Compston and Kröner (1988); Kröner and Tegtmeyer (1994);Zeh et al. (2011); Hoffmann et al. (2016)

Ashwal (1993, 2010); Pease et al. (2008); Furnes et al. (2012, 2015)

Barton (1996); Mouri et al. (2009); Keeditse (2016)

Ashwal (1993); Ryan and Martineau (2012); Sałacińska et al. (2019)

Naqvi and Hussain (1979); Kutty et al. (1984); Kunugiza et al. (1996); Rao et al. (2000)

Naqvi and Hussain (1979); Kutty et al. (1984); Kunugiza et al. (1996); Rao et al. (2000)

Ashwal (1993); James et al. (2002)

Paixão and Oliveira (1998)

Mondal and Zhou (2010); Sunder-Raju et al. (2015)

Mondal and Zhou (2010)

Ashwal (1993), Devaraju et al. (2009); Mukherjee et al. (2010)

Ashwal (1993); Mukherjee et al. (2010)

Mondal and Zhou (2010); Chakraborti et al. (2015)

Ghosh et al. (2019)

Polat et al. (2008a); Furnes et al. (2015)

Polat et al. (2008b); Ordóñez-Calderón et al. (2009, 2011)

Maier et al. (2003); Schmitz et al. (2004); Anhaeusser (2019)

Dantas et al. (2013)

Hoatson and Sun (2002)

Wiener (1981)

Ashwal (1993); Hughes et al. (2014)

Ashwal (1993); Kunugiza et al. (1996)

Dearnley (1963); Garson and Livingstone (1973)

Watson (1969); Hughes et al. (2014)

Bridgwater and Collerson (1977)

Bowes et al. (1964); Hughes et al. (2014)

Bowes et al. (1964); Hughes et al. (2014)

Bowes et al. (1964); Hughes et al. (2014)

Hoffmann et al. (2012)

Polat et al. (2011); Huang et al. (2014)

Ashwal (1993); Zeh et al. (2013)

Ashwal (1993); Hoatson and Sun (2002); Van Kranendonk et al. (2002)

Hoatson and Sun (2002)

Kudryashov and Mokrushin (2011)

Windley and Garde (2009); Souders et al. (2013)

Berger et al. (2013)

Berger et al. (2013)

Ashwal (1993); Dar et al. (2014)

Sultan et al. (1994); Zhang et al. (2018)

Motuza et al. (2001a,b); Corfu et al. (2003)

Motuza et al. (2001a,b); Corfu et al. (2003)

Motuza et al. (2001a,b); Corfu et al. (2003)

Motuza et al. (2001a,b); Corfu et al. (2003)

Motuza et al. (2001a,b); Corfu et al. (2003)

Motuza et al. (2001a,b); Corfu et al. (2003)

Motuza et al. (2001a,b); Corfu et al. (2003)

Motuza et al. (2001a,b); Corfu et al. (2003)

Motuza et al. (2001a,b); Corfu et al. (2003)

Motuza et al. (2001a,b); Corfu et al. (2003)

Accioly (2000); Brito (2000); Raimundo (2008); Teixeira et al. (2010); Barkov et al. (2015)

Motuza et al. (2001a,b); Corfu et al. (2003)

Motuza et al. (2001a,b); Corfu et al. (2003)

Motuza et al. (2001a,b); Corfu et al. (2003)

Motuza et al. (2001a,b); Corfu et al. (2003)

Motuza et al. (2001a,b); Corfu et al. (2003)

Motuza et al. (2001a,b); Corfu et al. (2003)

Motuza et al. (2001a,b); Corfu et al. (2003)

Motuza et al. (2001a,b); Corfu et al. (2003)

Kuzmich (2014); Metsaranta et al. (2015); Sappin et al. (2015)

Kuzmich (2014); Metsaranta et al. (2015); Sappin et al. (2015)

Ahmat and De Laeter (1982); Ivanic et al. (2010)

Ordóñez-Calderón et al. (2009, 2011)

Van Kranendonk and Helmstaedt (1990); Ashwal (1993)

Van Kranendonk and Helmstaedt (1990); Ashwal (1993)

Garde and Steenfelt (1999); Haugard et al. (2013)

Garde and Steenfelt (1999); Haugard et al. (2013)

Garde and Steenfelt (1999); Haugard et al. (2013)

Garde and Steenfelt (1999); Haugard et al. (2013) 
Hoatson and Sun (2002); Van Kranendonk et al. (2002)

Hoatson and Sun (2002); Van Kranendonk et al. (2002)

Hoatson and Sun (2002); Van Kranendonk et al. (2002)

Hoatson and Sun (2002); Van Kranendonk et al. (2002)

Anhaeusser (2019)

Moores et al. (1993); Anhaeusser (2019)

Simmons et al. (1980); Windley and Garde (2009); Ashwal (2010)

Cameron (1992); Corkery et al. (1992); Jobin-Bevans (1997); Peck et al. (1998, 1999a)

Vrevskii (2016)

Ashwal (1993); Good et al. (2009); Mealin et al. (2013); Bécu et al. (2015); Houlé et al. (2015); Sotiriou et al. (2019a)

Yang (2013); Yang et al. (2013)

Yang et al. (2011); Ames and Houlé (2015); Bécu et al. (2015)

Yang et al. (2013)

Yang (2013); Yang et al. (2013); Houlé et al. (2015)

Yang et al. (2011); Yang and Gilbert (2014); Sotiriou et al. (2020)

Sultan et al. (1994); Zhang et al. (2018)

Kuzmich (2014); Houlé et al. (2015); Metsaranta et al. (2015); Sappin et al. (2015)

Kuzmich (2014); Carson et al. (2015); Houlé et al. (2015); Spath et al. (2015)

Kuzmich et al. (2015); Metsaranta et al. (2015)

Houlé et al. (2015); Kuzmich et al. (2015); Metsaranta et al. (2015)

Houlé et al. (2015); Kuzmich et al. (2015); Metsaranta et al. (2015)

Kuzmich (2014); Houlé et al. (2015); Metsaranta et al. (2015)

Kuzmich (2014); Houlé et al. (2015); Metsaranta et al. (2015); Sappin et al. (2015)

Ashwal (1993); Bédard et al. (2009); Polat et al. (2018b)

Sappin et al. $(2015,2016)$

Sotiriou et al. (2019b)

Ashwal (1993); Wu et al. (2016); Zhou et al. (2016)

Raedeke and McCallum (1984); Ashwal (1993); Boudreau et al. (1997); Baker and Boudreau (2019)

Motuza et al. (2001a,b); Bergh et al. (2012)

Williams (1988, 1989); Ashwal (1993)

Ermanovics and Davison (1976); Bell (1978); Ashwal (1993); Peck et al. (1998, 1999a); Windley and Garde (2009)

Ashwal (1993); Polat et al. (2018a)

Ermanovics and Davison (1976); Bell (1978); Peck et al. (1996, 1998, 1999a); Windley and Garde (2009)

Ashwal (1993); Windley and Garde (2009)

Ashwal (1993); Windley and Garde (2009)

Ermanovics and Davison (1976); Bell (1978); Ashwal (1993); Peck et al. (1998, 1999a); Windley and Garde (2009)

Ashwal (1993); Windley and Garde (2009)

Williams (1988, 1989); Ashwal (1993)

Ermanovics and Davison (1976); Bell (1978); Ashwal (1993); Peck et al. (1998, 1999a); Windley and Garde (2009)

Haggerty et al. (1988); Williams (1988, 1989); Ashwal (1993)

Ermanovics and Davison (1976); Bell (1978); Peck et al. (1998, 1999a); Hartlaub and Kuiper (2004); Hartlaub et al. (2004a); Windley and Garde (2009)

Bridgwater et al. (1974); Ashwal (1993)

Acosta-Gongora et al. (2018a)

Ashwal (1993); Sandeman et al. (2001); Hartlaub et al. (2004b)

Bridgwater et al. (1974); Ashwal (1993)

Blichert-Toft et al. (1995)

Blichert-Toft et al. (1995)

Blichert-Toft et al. (1995)

Blichert-Toft et al. (1995)

Ashwal (1993); Kudryashov and Mokrushin (2011); Chashchin et al. (2012)

Vrevskii (2016)

Kudryashov and Mokrushin (2011)

Kudryashov and Mokrushin (2011)

Isachsen and Bowring (1994); Cousens (2000); Furnes et al. (2015)

Ashwal (1993, 2010); Mukherjee and Das (2002); Tenczer et al. (2006)

Acosta-Gongora et al. (2018b)

Larin et al. (2006); Larin (2009)

Ashwal (1993); Devaraju et al. (2002); Naqvi and Prathap (2007)

Ashwal (1993); Santosh and Li (2018)

Piaia et al. (2017)

de Paula Garcia et al. (2018)

Ashwal (1993); Mukherjee and Das (2002)

Ashwal (1993); Mukherjee and Das (2002)

Leatherdale et al. (2013)

Santosh et al. (2013)

Mohan et al. (2013); Rao et al. (2013)

Yellappa et al. (2012)

Ashwal (1993); Sharkov et al. (2004, 2006)

Borthwick and Naldrett (1986); Ashwal (1993); Maier and Groves (2011); Laarman (2013)

Zhou and Bai (1992)

Bridgwater et al. (1974); Ashwal (1993)

Yellappa et al. (2014)

Praveen et al. (2014)

Figueiredo (1989)

Samuel et al. (2014)

Santosh et al. (2016)

Ashwal (1993); Sharkov et al. (2004, 2006)

Ashwal (1993); Schulz et al. (2007)

Accioly (2000); Girelli et al. (2016); Oyhantçabal et al. (2018) 